Portland State University

PDXScholar

$1-1-2011$

\title{
The Pursuit of Commerce: Agricultural Development in Western Oregon, 1825-1861
}

Cessna R. Smith

Portland State University

Follow this and additional works at: https://pdxscholar.library.pdx.edu/open_access_etds Let us know how access to this document benefits you.

\section{Recommended Citation}

Smith, Cessna R., "The Pursuit of Commerce: Agricultural Development in Western Oregon, 1825-1861" (2011). Dissertations and Theses. Paper 258.

https://doi.org/10.15760/etd.258

This Thesis is brought to you for free and open access. It has been accepted for inclusion in Dissertations and Theses by an authorized administrator of PDXScholar. Please contact us if we can make this document more accessible: pdxscholar@pdx.edu. 
The Pursuit of Commerce: Agricultural Development in Western Oregon, $1825-1861$

by

Cessna R. Smith

A thesis submitted in partial fulfillment of the

Requirements for the degree of

Master of Arts

in

History

Thesis Committee:

William L. Lang, Chair

David A. Horowitz

David A. Johnson

Barbara A. Brower

Portland State University

(C)2011 


\section{ABSTRACT}

This thesis examines how the pursuit of commercial gain affected the development of agriculture in western Oregon's Willamette, Umpqua, and Rogue River Valleys. The period of study begins when the British owned Hudson's Bay Company began to farm land in and around Fort Vancouver in 1825, and ends in 1861-during the time when agrarian settlement was beginning to expand east of the Cascade Mountains. Given that agriculture in Oregon, as elsewhere, would eventually reach a standard of national development, and given that most of

Oregon's immigrants arrived poor and lacked the farm implements needed for subsistence, the question this study asks is what methods and motivations guided Oregon's first agrarian settlers to improve their industry? It is the central premise of this study that commerce was the sine qua non of agricultural development, and that commercial gain was the incentive that underpinned the improvements necessary to its progress. The question itself necessarily involves physiographical and climatological conditions, existing and potential markets, and a merchant class whose commercial motivations were beyond doubt.

Two additional matters that weigh substantially through most of this paper need to be mentioned: First, because not all farmers were commercially-oriented, the focus is on individuals, including merchants, whose entrepreneurial activities contributed the most to agriculture; second, the discovery of gold in California in 1848, and in southern Oregon in the early 1850s, had a huge and lasting influence on Oregon agriculture and on the overall economy. 


\section{DEDICATION}

For my beautiful daughters Stacey, Tracey, and Kelsey. 


\section{ACKNOWLEDGEMENTS}

Special appreciation goes to my advisor, Professor William L. Lang, whose optimism, on several occasions, renewed my determination to finish this project. He was always available to share his immense knowledge of both the Pacific Northwest and the finer points of thesis writing. His immediate recognition of an off-topic idea, or any other errant path taken, was very important as a reminder to me that focus and consistency are integral to a manuscript of this nature. 


\title{
TABLE OF CONTENTS
}

\author{
Abstract / i \\ Dedication / ii \\ Acknowledgements / iii \\ List of Figures / $\mathbf{v}$ \\ List of Abbreviations / vi \\ Introduction / 1 \\ Chapter One:
}

Agriculture Begins: Hudson's Bay Company and the Settlement of the Willamette Valley / 20

Chapter Two:

Oregon's First Farm Cooperatives: Willamette Cattle Company (WCC), Joseph Gale Venture, and the Oregon Producers' Exporting and Importing Company (OPEIC) / 46

Chapter Three:

1848: Gold, Growth, Towns and Transportation / 68

Chapter Four:

Agricultural Conditions / 88

Chapter Five:

Umpqua and Rogue River Valleys / 108

Chapter Six:

County and State Agricultural Societies / 123

Conclusion / 136

References / 141 


\section{LISTOF FIGURES}

Figure 1. Map of Western Oregon (1851) / 155

Figure 2. Map of Lower Willamette Valley (1834) / 156 


\section{LIST OF ABBREVIATIONS}

$\begin{array}{ll}\text { DLC } & \text { Donation Land Claim } \\ \text { HBC } & \text { Hudson's Bay Company } \\ \text { OFGA } & \text { Oregon Fruit Growers' Association } \\ \text { OHQ } & \text { Oregon Historical quarterly } \\ \text { OHS } & \text { Oregon Historical Society } \\ \text { OPEIC } & \text { Oregon Producer's Exporting and Importing Company } \\ \text { OSAS } & \text { Oregon State Agricultural Society } \\ \text { PNQ } & \text { Pacific Northwest Quarterly } \\ \text { PSAC } & \text { Puget Sound Agricultural Company } \\ \text { TOPA } & \text { Transactions of the Oregon Pioneer Association } \\ \text { WCC } & \text { Willamette Cattle Company }\end{array}$




\section{Introduction}

Every business in life is mainly dependent, for its prosperity, upon the labors of agriculture.

- Jesse Buel, The Cultivator (August 1836)

The history of Oregon agriculture is essentially a history of the pursuit of commercial gain. From the cattle company created by settlers in 1837 , to the county and state agricultural societies they created between 1853 and 1861, their overarching goal was individual and community economic enrichment. This thesis seeks to know how the pursuit of commercial gain affected the course of agricultural development in the Willamette, Umpqua, and Rogue River Valleys by examining the subjects that measure its progress: economic organizations; improvement of plants, livestock, and cultivation practices; farm groups and individuals; gold mining; towns; and transportation.

The Willamette, Umpqua, and Rogue River Valleys comprise the area of study. Primary focus is on the Willamette Valley because it is where Oregon pioneers first began to settle, and it is where agricultural development first began. ${ }^{1}$ The Willamette Valley lies between the Cascade Range to the east, the Coast Range to the west, and surrounds the Willamette River as it flows north from near Eugene to its confluence with the Columbia River. Approximately 130 miles long and between 20 and 30 miles wide for most of its length, it first caught

\footnotetext{
${ }^{1}$ Joseph Shafer, ed., "Documents Relative Warre and Vavasour's Military Reconnoisance [sic] in Oregon, 1845-6," Oregon Historical Quarterly 10 (March 1909). Overland immigrants began to settle the Willamette Valley in the early 1830 s, while settlement of southern Oregon valleys did not begin until well into the 1840s.
} 
the attention of pioneer farm immigrants because of its productive soil and the navigability of the Willamette River and its many tributaries. ${ }^{2}$

American settlers who immigrated to Oregon's Willamette Valley in the 1830s through the 1850 s were motivated by what historians have come to recognize as an overlapping mix of concerns and attractions most commonly related to health, economics, and free land, and the great majority of them were either farmers or those who depended on farming for economic reasons. ${ }^{3}$ In his study of migration patterns, William A. Bowen, in The Willamette Valley: Migration and Settlement on the Oregon Frontier (1976), found that the majority of immigrants came from the Midwest and Upper South, and of the Midwesterners a majority had either immigrated from or had cultural ties to the Upper South, ${ }^{4}$ Clarence H. Danhof in Change in Agriculture: The Northern United States, 1820-1870 (1969), and John Mack Faragher, in Women and Men on the Overland Trail (1979) argue that free land and commercial opportunity were the primary motivators for Oregon's immigration. ${ }^{5}$ William A. Bowen argues that physical health and economics were

${ }^{2}$ D. W. Meinig, The Great Columbia Plain: A Historical Geography, 1805-1910 (Seattle: University of Washington Press, 1995), 96-124 passim; William A. Bowen, The Willamette Valley: Migration and settlement on the Oregon Frontier (Seattle: University of Washington Press, 1976), 6-7.

${ }^{3}$ Bowen, 17-24.

${ }^{4}$ Bowen, 24-27. For this paper, and elsewhere generally acknowledged, the Midwest states are: Illinois; lowa; Kansas; Indiana; Michigan; Minnesota; Missouri; Nebraska; North Dakota; South Dakota, Ohio; and Wisconsin. Upper South states are: Kentucky; Tennessee; Virginia; and North Carolina. Peter G. Boag, Environment and Experience: Settlement Culture in Nineteenth Century Oregon (Berkeley: University of California Press, 1993), 30, found that of the children of 161 Donation Land Claimants who filed in the Kalapuya Valley between 1850 and 1855, only 3 percent were born outside the Midwest and Upper South. Boag considered the Kalapuya to be a microcosm of the Willamette Valley "Historically, culturally, and environmentally," (p. 42).

${ }^{5}$ Clarence H. Danhof, Change in Agriculture: The Northern United States, 1820-1870 (Cambridge: Harvard University Press, 1969), 149-150; John Mack Faragher, Women and Men on the Overland Trail (New Haven: Yale University Press, 1979), 17-18. 
coequal motivations, but that once settlement was established the "typical Oregon farm was a commercial enterprise."

In Oregon's agrarian community, the word Improvement commonly referred to the pursuit of better crops, livestock, methods of production, and laborsaving implements. Although the idea was often expressed in conjunction with agricultural sciences and the virtues of men who worked the soil, its principal meaning was more accurately understood as a method for commercial gain. ${ }^{7}$ Nowhere is this dual meaning more clearly acknowledged than in nearly all of many speeches delivered at agrarian events, as in this excerpt from a speech made by Yamhill Agricultural Society President Ahio Watt at his annual county fair in 1859: ${ }^{8}$

We have again met in ... rivalry [competitive exhibits]. ... we have brought samples from our herds and fields; our orchards and gardens; our dairies and households. It is a source of pleasure, as well as profit, to meet in these yearly gatherings. Here is exhibited the evidence of present prosperity ....

In 1860, Oregon Chief Justice George H. Williams delivered a lengthy encomium filled speech to the Multnomah County Agricultural Society, commenting that

\footnotetext{
${ }^{6}$ Bowen, 18-21, 96.

7 Danhof, 16; Nationally, Danhof states that "self-improvement," or economic gain, usually meant "accumulating lands." Farmers in Oregon, however, averaged much larger land holdings than they held before immigrating, and "improvements" were commonly understood as raising purebred livestock or any success in raising the yields and standards of agricultural production. For average farm size in the Midwest, see David Alan Johnson, Founding the Far West: California, Oregon, and Nevada, 1840-1890 (Berkeley: University of California Press, 1992), 47; Ohio farms, for example, averaged 125 acres in 1850, while farms in Oregon averaged 372 acres.

8 "Address of A. S. Watt Esq., Before the Yamhill Agricultural Society, at McMinnville," Oregon Farmer, November 25, 1859.
} 
exhibits at agricultural fairs advertise improvements and thereby "reward the diligent with a ready market and high price."

However, while many Oregon farmers were interested in improvements and in producing surpluses for the market, historians have presented the case that most were not commercially oriented enough to make a financial success of their farms; the evidence most often used are editorials and letters to the editor that accuse Oregon farmers of being indifferent and lacking industry. ${ }^{10}$ Closely linked to these charges were widely held stereotypes that depicted southern culture as the crucible in which indolent farmers were nurtured. ${ }^{11}$ That these familiar perceptions emerged in Oregon is not surprising given the numerical strength of Southerners, and particularly in the mid-Willamette Valley farm community where they represented more than half of Oregon's population and owned four-fifths of the improved land. ${ }^{12}$

Historians have long recognized regional cultural differences in politics and the pursuit of wealth and stature. Dean May's study, Three Frontiers: Family, Land, and Society in the American West, 1850-1900 (1994), articulates the

\footnotetext{
${ }^{9}$ George H. Williams' speech to the Multnomah County Agricultural Society in the Oregon Farmer, July 21, 1860.

${ }^{10}$ David Alan Johnson, Founding the Far West: California, Oregon, and Nevada, 1840-1890 (Berkeley: University of California Press, 1992), 46-48-also see note 15, p. 398; Thockmorton, 161. In one of many allusions to indolence, the Oregon Farmer, March 15, 1862, editorialized that farmers' cost themselves upwards of a half million dollars because they failed to store enough feed for either themselves or their livestock during the severe winter just past.

${ }^{11}$ Raised on a farm in Illinois by parents who had emigrated from the Upper South, Harvey Whitfield Scott immigrated to Oregon in 1852, earned a law degree at Pacific University, and became editor of the Oregonian (1866-1872 and 1877-1910). The author/compiler of a six volume history of Oregon, Scott was a contemporary observer of differences in regional cultures. In an article, "Habits of Oregon in the Early Time," Oregon Historical Quarterly 18 (March-December 1917): 247, 253, Scott remarked that "Yankees" from New England and New York were merchants and speculators who took to urban life and were a "class apart" from backwoods Mississippi Valley farmers who settled in the Willamette Valley.

12 Johnson, 56-57.
} 
differences between entrepreneurial northern (Yankee) farmers and less enterprising farmers from the South who settled in Sublimity, Oregon; for example, northern Yankees were judged to be acquisitive and ambitious while Southerners were judged to be less so. ${ }^{13}$ Nicole Etcheson, in The Emerging Midwest: Upland Southerners and Political Culture of the Old Northwest, 17871861 (1996), and Susan Sessions Rugh in Our Common Country (2001), also remark on enterprising urban Northerners and complacent southern farmers. ${ }^{14}$ In regard to politics, David Alan Johnson, in Founding the Far West: California, Oregon, and Nevada, 1840-1890 (1992), describes Oregon's blend of immigrants as a contrast of urban anti-Democrats from New England and Mid-Atlantic States, and rural Democrats from the South. ${ }^{15}$

While it is true that the contemporary literature presented many disparaging comments about the complacency of Oregon farmers, the issue is more complex than such anecdotal evidence suggests. In their study of 12,000 midwestern and northeastern farm households, economists Atack and Bateman found, in general, that farmers were motivated by three goals: independence; self-sufficiency; and

\footnotetext{
${ }^{13}$ Dean L. May, Three Frontiers: Family, Land, and Society in the American West, 1850-1900, (Cambridge: Cambridge University Press, 1994), 177-178.

${ }^{14}$ Nicole Etcheson, The Emerging Midwest: Upland Southerners and the Political Culture of the Old Northwest (Bloomington: Indiana University Press, 1996), 4-5; Etcheson notes that Jefferson described Northerners as "laborious, and Southerners as "indolent". See also Susan Sessions Rugh, Our Common Country: Family Farming, Culture, and Community in the Nineteenth-Century Midwest (Bloomington: Indiana University Press, 2001), 30, in which New Englanders are described as "profit-minded," and Southerners as less aggressive in the marketplace.

${ }^{15}$ For a description of Anti-Democrats see David Alan Johnson, Founding the Far West: California, Oregon, and Nevada, 1840-1890 (Berkeley: University of California Press, 1992), 5861.
} 
commercial success. ${ }^{16}$ The authors also recognized that iconographic agrarian ideals, such as identification with America's virtuous yeoman farmer, attracted and retained men into agricultural professions. Using the 1860 agriculture and population censuses, the authors compared profits in the Midwest and the Northeast and found that midwestern farmers produced more marketable surpluses than did northeastern farmers. ${ }^{17}$ This finding challenges the stereotype that Yankees were more productive than Southerners-the dominant cultural heritage of most Midwesterners. Their work also provides evidence that commercial motivations significantly influenced single family farm production in both the Midwest and the Northeast.

Whether or not regional cultures had any effect on overall agricultural production and the pursuit of commerce in pioneer Oregon has never been given an examination on the scale of the Atack and Bateman study. However, there are data that contradict the assumption that Oregon farmers productively lagged their national counterparts. The 1850 and 1860 agricultural census records reveal that Oregon's average wheat and butter production per farmer compared well with the average production of these same staples by their occupational peers in Midwest and New England states, and bested California by far in 1850. Comparative statistical data demonstrating that Oregon agricultural production of wheat in 1850 and 1960 either matched or bested national averages is presented in chapter five.

\footnotetext{
16 Jeremy Atack and Fred Bateman, To Their Own Soil: Agriculture in the Antebellum North (Ames, lowa: University of lowa Press, 1987),10-14.

${ }^{17}$ Atack and Bateman, 226.
} 
The purpose of introducing regional cultures and matters of national agricultural production is threefold: First, knowledge of cultural values provides context for examining the community's behavior as it pursued commerce and contributed to the development of agriculture. Second, evidence is introduced that contradicts historical assumptions that Oregon farmers were, either because of regional heritage or other causes, less productive than were farmers in other communities; in fact, many of Oregon's most commercially successful farmers had cultural roots in the South. ${ }^{18}$ Third, it touches on the conceptual framework underpinning this thesis, which is that entrepreneurial Oregon farmers, from all regions of the United States, bore the brunt of responsibility for the development of Oregon agriculture.

Entrepreneurial farmers led in the improvements to their industry that were essential to its commercial expansion and development. Among the best representatives were: sheep breeders John Minto and brothers Ahio and Joseph Watt; cattle breeder R.C. Geer; horticulturalists Seth and Henderson Lewelling; farmer and steamboat owner James D. Miller; and farmer, surveyor, and trail blazer Jesse Applegate. They were involved in agricultural societies, exhibited competitively at agricultural fairs, and promoted changes that benefited the working farmer. Later chapters describe the efforts of these and other successful men.

The most comprehensive work on early Oregon agriculture is Michael Leon Olsen's" The Beginnings of Agriculture in Western Oregon and Western

\footnotetext{
${ }^{18}$ The Luelling, Applegate, and Riddle families (discussed in other chapters) were successful entrepreneurs whose cultural roots were in the Upper South.
} 
Washington," Ph.D. diss., University of Washington, (1971). Olsen chronicles the development of agriculture in western Oregon and Washington to year 1900. This thesis covers most of the subjects and important characters in Olsen's work, but it differs in bringing more focus to agricultural commerce as it involves transportation, improvements for the sake of commercial gain, the significance of the agricultural societies, and the Umpqua and Rogue River Valleys (Olsen does not discuss these southern Oregon valleys).

The Umpqua and Rogue Valleys of southern Oregon contained sections of rich alluvial soil equal to that found in the Willamette Valley. However, most overlanders preferred to settle in the Willamette Valley because of its expansive plains and the commercial advantages of its extensive system of navigable waterways. But there were others like the George Riddle family who decided to settle in the southern valleys even before emigrating west. The Riddles moved into the Rogue Valley in the early 1850s where they began farming, sold their wheat to local flour mills, and established a successful plow fabricating business. When the weather was dry, they traveled 170 miles to Oregon City on ox-drawn wagons where they sold plows and purchased metal for their business. Others, like farmers Jesse and Lindsey Applegate, and Levi Scott, left their homes in Polk County and settled with their families in the Umpqua Valley. ${ }^{19}$

American immigrants began moving into the area of the Umpqua and Rogue Valleys in 1846 after Jesse Applegate led members of the South Road Company in blazing a new emigrant trail (Applegate Trail) from southern Oregon to near

\footnotetext{
${ }^{19}$ Harold Avery Minter, Umpqua Valley, Oregon and its Pioneers (Portland, Oregon: Binfords and Mort, 1967), 52.
} 
Fort Hall, Idaho. On his return trip, Applegate helped guide a party of immigrants via this route, some of whom took refuge at Fort Umpqua (HBC post) over the winter of $1846-1847$, and then decided to settle there. ${ }^{20}$ Settlers in both the Willamette and the southern Oregon valleys trod the same connecting passages, produced, bartered, sold, purchased the same goods and services, and shared in the common experiences of everyday life in Oregon's farm community west of the Cascades.

A. G. Wallings' History of Southern Oregon, Comprising Jackson, Josephine, Douglas, Curry, and Coos Counties (1884) provided a basic source for information on the Umpqua and Rogue River Valleys. ${ }^{21}$ There is no comprehensive work on both southern valleys more recent than Wallings' 1884 work, and there appears to be no major work on the Umpqua Valley. There are at least two Ph.D. dissertations for the Rogue River Valley: In 1973, Jerilyn Sue Mcintyre completed her dissertation on the structure of communication in Jacksonville; and in 1952, Jesse Lee Gilmore completed his dissertation on the pioneer history of the Rogue River Valley. ${ }^{22}$ Mcintyre's work was valuable for its description of conditions after gold was discovered in Jacksonville over the winter of 1851-1852. Her work also included pertinent information about pack trains and supply routes. Gilmore's work was valuable for information on agricultural conditions in the Rogue Valley, and for his conclusion that agricultural production

\footnotetext{
${ }^{20}$ Minter, 39-51.

${ }^{21}$ A. G. Walling, History of Southern Oregon, Comprising Jackson, Josephine, Douglas, Curry, and Coos Counties (Portland, Oregon, 1884).

${ }_{22}$ Jerilyn Sue Mcintyre, "The Structure of Communication in an Emerging Frontier Community: Jacksonville, Oregon 1852-1856" (Ph.D. diss., University of Washington, 1973); Jesse Lee Gilmore, "A History of the Rogue River Valley-Pioneer Period, 1850-1962" (Ph.D. diss., University of California, 1952).
} 
was used primarily for home consumption, and for a "limited amount of goods transported over hard, difficult ... routes" to local market opportunities. ${ }^{23} \mathrm{~A}$ few sources that are not in complete agreement with Gilmore's conclusion are included in the Rogue Valley pages of this thesis (chapter five).

Between 1818 and 1846 the Oregon Country was held in joint custody by Great Britain and the United States. This territory was bordered by the Pacific Ocean, and lay west of the Rocky Mountains between latitudes $54^{\circ} 40^{\prime}$ and $42^{\circ}$. Joint custody ended in 1846 with the signing of the Oregon treaty that established the boundary between the two nations at the $49^{\text {th }}$ parallel. In 1848 , a United States Congressional Act gave territorial status to the Oregon Country, then encompassing present day Oregon, Washington, Idaho, and parts of Wyoming and Montana. Until the mid 1850s, when its best lands had been claimed, the Willamette Valley remained the destination of choice for Oregon immigrants.

The British-owned Hudson's Bay Company (HBC) was important to Oregon agricultural development on three important levels: The company developed agricultural expertise by farming in the Oregon Country to the north of the Columbia River at Vancouver and, to a lesser extent, in the Willamette and Umpqua Valleys more than a decade before American settlers began to arrive in the early 1830s; the company shared its agricultural expertise with American immigrants and supplied them with essential farming implements, seeds and livestock; and the HBC was the principal center of trade in the region until the

${ }^{23}$ Gilmore, 323-324. 
mid 1840s. However, some HBC business decisions were considered monopolistic, and three American farmer-led economic organizations formed to circumvent them: The Willamette Cattle Company (WCC); the Joseph Gale Venture; and the Oregon Producers' Exporting and Importing Company (OPEIC).

In 1837, settlers organized the WCC and, in 1841, settlers organized the Joseph Gale venture-both organizations were created for the purpose of buying cattle in California and driving the herds overland to the Willamette Valley. Before 1843, the HBC owned nearly all cattle, and the company would not sell them. This was a hardship on the settlement because ownership of cattle represented a degree of wealth, and they were commonly used as a medium of exchange in the nearly cashless settlement community. The successes of the WCC and the Gale venture enriched both individuals and community, and helped to break the HBC cattle monopoly. In 1847, settlers formed the Oregon Producers Exporting and Importing Company (OPEIC) in order to combat a shipping and marketing monopoly by the HBC and American merchants. All three organizations were driven by economic concerns, and each organization had an important role in the history of agricultural development. The formation of the OPEIC was a milestone for farmers because it demonstrated that they had surplus wheat for sale, and that they had the capacity to finally wrest themselves from dependence on the HBC's export markets.

News of the California gold discovery came to Oregon in August 1848. By that fall, it was estimated that two-thirds-about 3,000—of the male population had 
left for California. ${ }^{24}$ Records are incomplete, but the historiography regarding the affect of the gold rush on Oregon recognizes that although many farmers abandoned their farms, most of them returned within a year or two. ${ }^{25}$ Arthur L. Throckmorton, who wrote Oregon Argonauts (1961), noted that between 1849 and 1853 Oregon farmers profited primarily from rising prices and not from surplus production per se. ${ }^{26}$ William A. Bowen, The Willamette Valley: Migration and Settlement on the Oregon Frontier (1978), wrote that agricultural production was stagnant for two years following the gold rush because many farmers had left for the mines. ${ }^{27}$

However, there can be little doubt that that the influx of gold into Oregon boosted agricultural production after 1850-by December, 1849, an estimated $\$ 5,000,000$ entered the economy from men, many of them farmers, who returned from the gold mines. ${ }^{28}$ Farmers who returned early enough to plant their crops in early 1849 to the spring of 1850 realized huge profits from two years of summer harvests. Wheat that sold for six dollars a barrel in August 1848, sold as high as fifteen dollars a barrel by December. ${ }^{29}$ Rapid population growth in California precipitated an urgent need for Oregon's wheat, and Willamette Valley flour mills

\footnotetext{
${ }^{24}$ Arthur L. Throckmorton, Oregon Argonauts: Merchant Adventurers on the Western Frontier (Portland, Oregon: Oregon Historical Society, 1961), 88; ;Bancroft, History of Oregon 2: 42-43. ${ }^{25}$ Throckmorton, 89; Bowen, 14.

${ }^{26}$ Throckmorton, 98-99..

${ }^{27}$ Bowen, 90-91.

${ }^{28}$ Throckmorton, 105.

${ }^{29}$ According to the Oregon Spectator, April 18, 1850, five bushels of wheat went into making one barrel of flour.
} 
moved quickly to meet the demand. In 1849 , flour mills at Oregon City and elsewhere in the valley "flourished" while new mills were being constructed. ${ }^{30}$

Passable roads and navigable streams between farm and market were vital to the economy of Oregon's growing agricultural settlement. Farmers removed obstacles to river navigation, built ferries, and blazed trails to river landings and trade routes, but they were by no means alone in improving these passages. Shipping merchants introduced steamboats into the lower and upper Willamette River in the early 1850 s. $^{31}$ Transportation improvements were a community-wide endeavor that concerned merchants, travelers, the military, and farmers alike. Large projects that required money and labor beyond the means of local farmers and merchants required the investment of government; for example, the federal government aided farmers in the Umpqua Valley by completing a military road from Scottsburg in the Umpqua Valley to the California-Oregon Road in $1858 .{ }^{32}$

Oregon pioneers were familiar with petitioning the government for roads as it was a common practice in the frontier communities they left behind. In Sugar Creek (1986), a study of an Illinois frontier community, John Mack Faragher noted that between 1846 and 1860 Sugar Creek men filed sixty-one petitions with the Sangamon County Commissioners. ${ }^{33}$ Sugar Creek farmers, like their Oregon counterparts, believed that improved transportation between farm and

\footnotetext{
${ }^{30}$ Throckmorton, 94.

${ }^{31}$ Howard McKinley Corning, Willamette Landings: Ghost Towns of the River (Portland, Oregon: Oregon Historical Society, 1947), 23-25.

32 John B. Horner, Her History, Her Great Men, Her Literature (Corvallis, Oregon: 1919), 132-133.

${ }^{33}$ John Mack Faragher, Sugar Creek: Life on the Illinois Frontier (New Haven: Yale University

Press, 1986), 188.
} 
market was the best way to ensure fair prices for agricultural surpluses. ${ }^{34}$ In 1856, with funding from the State of Oregon and Portland merchants, the Canyon Toll Road was completed from Portland to Lafayette-the center of agricultural trade in the 460,000 acre Tualatin Plains. ${ }^{35}$ Oscar Osburn Winther's The Old Oregon Country: A History of Frontier Trade, Transportation, and Travel (1950) contains more information on western Oregon's early roads than any other of numerous books and articles consulted for this paper. Winther also authored several articles on early Oregon roads for the Oregon Historical Quarterly and they are listed in this paper's bibliography.

Howard McKinley Corning's Willamette Landings: Ghost Towns of the River (1973) is the most comprehensive work on river transportation in the Willamette Valley during the period of this study. Economic ties between Oregon farmers and merchants provided the principal impetus for the establishment of towns that sprang up near river landings, major trade routes, and trade centers. Oregon City and Canemah came into being because of their strategic locations as portage points for commerce around the Willamette Falls. ${ }^{36}$ Canoes and flatboats would bring wheat from the upper Willamette to Canemah, and from there the wheat was transported by ox-drawn wagons one-half mile north to Oregon City in the lower river. ${ }^{37}$ Upriver, the shipping points of Champoeg, Butteville, Fairfield Landing, Lincoln, and Wheatland competed for mid Willamette Valley wheat.

\footnotetext{
${ }^{34}$ Faragher, 188.

${ }^{35}$ E. Kimbark MacColl, Merchants, Money, and Power: The Portland Establishment, 1843-1913 (USA: The Georgian Press, 1988), 51-53. Acreage quoted is from Rodman W. Paul, "After the Gold Rush: San Francisco and Portland," Pacific Historical Review 51 (February 1982): 11.

${ }^{36}$ Corning, 8; Oregon Farmer, May 1, 1861.

${ }^{37}$ Corning, 58.
} 
These once thriving river ports and their warehouse/granaries arose solely to accommodate an increasing flow of agricultural traffic. However, the flood of 1861-1862 destroyed Champoeg, and the rest of the landing towns either disappeared or lost significance after the introduction of railroads (late 1860s) and a gradual decline in demand for Oregon wheat. ${ }^{38}$ Perhaps the best representation of agriculture's power to locate and determine the success of towns is demonstrated by the selection of Portland as Oregon's leading entrepôt because it had the best access to mid Willamette Valley wheat fields. ${ }^{39}$

Crops, cattle, sheep, hogs, and horticulture comprised the primary staples of Oregon's agricultural industry. Although no single work examines all efforts to improve these staples, there are many relevant sources. A few of the best works include: James R. Gibson's Farming the Frontier: The Agricultural Opening of the Oregon Country 1786-1846 (1985); William A. Bowen's The Willamette Valley: Migration and Settlement on the Oregon Frontier (1978); and Michael Leon Olsen's "The Beginnings of Agriculture in Western Oregon and Western Washington," Ph.D. diss., University of Washington, (1971). Gibson was useful for information about the HBC's Vancouver farm, Willamette Valley settlement, and the company's relationship with Oregon farmers. Bowen was most valuable for census and other government manuscript references, and for summaries regarding agricultural commodities and conditions. Olsen is discussed earlier in this introduction.

\footnotetext{
${ }^{38}$ Corning, 70-107.

${ }^{39}$ See "Canyon Road," p. 75.
} 
Among primary sources used are William A Slacum's "Report on Oregon," Charles Wilkes Narrative of the United States Exploring Expedition (1856), and John McLoughlin's letter, "Copy of a Document Found among the Private Papers of the Late Dr. John McLoughlin." Slacum and Wilkes, both U.S. Navy officers on missions to inspect the Oregon Country, provide reliable information on the HBC and the American Willamette Valley settlement in the late 1830 s and early 1840 s. McLoughlin's letter, discovered decades after his death, provides information on his relationship with American settlers-particularly his involvement with the American settler Ewing Young and the WCC.

Entrepreneurial farmers were the first to introduce commercial improvements to their industry. Improved breeds of livestock, for example, were seldom discussed without reference to value. Daniel Waldo, Marion County farmer, discovered a great demand for his blooded cattle when he arrived with his herd in 1843. Waldo said his cattle were valued at a hundred dollars apiece, while local Longhorns sold for nine dollars. ${ }^{40}$ Sometimes entrepreneur farmers involved in non-farm industries were also engaged in agricultural commerce. In the early 1850s, James D. Miller switched from owning and operating steamboats to starting a horticultural business on his donation land claim in the Tualatin Valley. The example set by Henderson Luelling, owner of Oregon's first successful horticultural operation, inspired Miller to plant his own orchards in the early 1850 s when fruit prices were sky high in California. Miller also improved navigation on the Yamhill River in order to access landings at Hillsboro and McMinnville where

${ }^{40}$ T. T. Geer, Fifty Years in Oregon (New York: Neale Publishing Company, 1912), 218; Bowen, 81. 
farmers brought their wheat for transport to Oregon City. ${ }^{41}$ Jesse Applegate, farmer and surveyor, led the trail-blazing party that opened up a new immigration route to southern Oregon-a trail that the George Riddle family and others followed to establish a homestead in the Umpqua Valley. ${ }^{42}$

The Yamhill County Agricultural Society formed in 1853; other counties followed suit until, by 1861 , there were at least thirteen county agricultural societies in western Oregon. These organizations gathered to form the Oregon State Agricultural Society (OSAS) in 1860. Although they were family inclusive, agricultural societies were patriarchal institutions formed by men for the primary purpose of economic gain. The societies sponsored annual fairs where farmers competed for best of place in exhibits that included all things agricultural. Society meetings and fairs, particularly State Fairs, were places for exchanging ideas and for promoting innovations. It was widely believed that competition would generate improvements in agriculture such as higher yielding grains, livestock, and labor reducing farm implements-all of which would translate into more profit in the marketplace. Men included family members in plans made for annual fairs, but separated the competitive exhibits and events by gender. Women competed in "Ladies Departments" that included best of show for millinery, knitting, painting, bread, and butter. ${ }^{43}$ Other activities included overnight camping sites for families, women's equestrian events, and competitive exhibits for children. The important

\footnotetext{
${ }^{41}$ James D. Miller, "'Early Oregon Scenes: A Pioneer Narrative," Oregon Historical Quarterly 31 (September 1930): 160-180.

${ }^{42}$ Joseph Schafer, "Jesse Applegate: Pioneer, Statesman, and Philosopher," Edmond S. Meany, ed., Washington Historical Quarterly 1 (July 1907): 217-233.

${ }^{43}$ Washington County Agricultural Society, "Secretary's Book," June 10, 1854.
} 
role of the agricultural societies in the development of agriculture in early Oregon is examined in chapter six of this paper.

The importance of the newspaper as both impetus and measure of influence and change affirms its importance in the study of the American frontier. Oregon's earliest newspapers were made particularly important because the country's isolation allowed them to hold sway over a captive audience. Frontier farmers had little time or inclination to keep diaries or journals, and, thus, contemporary newspapers are valuable primary resources for historical research. First published on February 5, 1846, the Oregon Spectator was the first Englishlanguage paper to appear in Oregon and it remained the Territory's only important paper until the Oregonian appeared in 1850. The Spectator immediately declared itself apolitical but otherwise open to all interests and elements of society. ${ }^{44}$ Although it did not have a reporter to send out and report on local farm activity, the Spectator consistently printed agricultural news and asked farmers to send in their letters and articles. Over the span of its existence (1846-1855), the Spectator was always attentive to the needs of the farm community. Other newspaper sources include the Oregonian (1850-), Oregon Statesman (1851-), and Democratic Standard (1854-1859); these and other Oregon newspapers are listed in the bibliography and most of them are available on microfilm at the Oregon Historical Society library. Especially helpful for researching the southern Oregon valleys were searchable online California

\footnotetext{
${ }^{44}$ In its first printing on Feb. 5, 1846, Editor W. G. T'Vault wrote that political discussion was off limits, but in the same editorial he also claimed the paper as a solid "democrat of the Jeffersonian School." Six weeks later he was fired for supporting Asa Lovejoy in an election. For a brief discussion of the paper's mercurial relationship with politics, see Warren J. Brier, "Political Censorship in the Oregon Spectator," Pacific Historical Review 31 (August 1962): 235-240.
} 
newspapers such as the Daily Alta California, Sacramento Daily Union, and the Sacramento Transcript. ${ }^{45}$

Pioneer newspaper editors recognized the rural dominance of Oregon's populace, and they recognized that their future was to a large degree dependent upon the successes of that growing audience. Editors emphasized agricultural improvement in their farm genre editorials and in publications gleaned from outside sources, and thus played a role in Oregon's agricultural development. ${ }^{46}$ Silverton historian Robert Down made known his high regard for newspapers when he wrote that any history of the Northwest must often confer with the vast and informative archives of the Oregon Statesman and the Oregonian. ${ }^{47}$

The significance of the farm paper in the pioneer period saw its apogee with the advent of the Oregon Farmer in 1858. Six months after its first publication the Farmer touted itself as now "... endeared in the hearts of the people," and claimed responsibility for a rebirth of farm organizations and for the renewal of a general interest in agriculture and horticulture. ${ }^{48}$ At the convention establishing the OSAS in February 1860, members named the Oregon Farmer as the Society's official "organ". 49

\footnotetext{
${ }^{45}$ California Digital Newspaper Collection, http://cdnc.ucr.edu/about_us.html

${ }^{46}$ Warren J. Bier, "A History of Newspapers in the Pacific Northwest" (Ph.D. diss., State University of lowa, 1957), 408.

${ }^{47}$ Robert Horace Down, A History of Silverton Country (Portland, Oregon: Berncliff Press, 1926), 244.

${ }^{48}$ Oregon Farmer, January 1859.

49 lbid, March 10, 1860.
} 


\section{CHAPTER ONE}

\section{Agriculture Begins: Hudson's Bay Company and the Settlement of the Willamette Valley}

Until the Treaty of 1846 settled the boundary dispute, the British-owned HBC, with its diverse trapping, lumber, agricultural, and shipping enterprise, had been Britain's mainstay in the political struggle with the United States for title to the Oregon Country. Although it had been HBC policy to discourage American immigration into the disputed territory, John McLoughlin, Chief Factor at Fort Vancouver from 1824 to 1846 , rendered aid to immigrants by lending them foodstuffs, farm implements, seed, building material, and other necessities as needed for subsistence farming. At the time Congress established Oregon as a United States Territory in 1848, the HBC still wielded considerable but waning influence over the agricultural pursuits of American immigrants-almost all of whom had chosen to settle in the Willamette Valley.

The HBC Columbia District headquartered first at Fort George, Astoria in 1821-23, and then moved one hundred miles upriver to the north side of the Columbia River at Fort Vancouver in 1824-25. In 1827, HBC Governor George Simpson merged the Caledonia and Columbia Districts to form the Columbia Department, and put McLoughlin in charge. The area encompassed the Oregon Country north from the $42^{\text {nd }}$ parallel to include the approximate boundaries of what is now British Columbia.

Simpson was intent on cutting costs and agricultural self-sufficiency was high 
on his list of economic reforms. ${ }^{50}$ Provisioning the Pacific Northwest by ship was costly, and there was an ongoing concern about damages to perishablesespecially flour. ${ }^{51}$ Suitability of the land for producing crops and raising livestock was Simpson's principal motive for the move to Fort Vancouver. ${ }^{52}$ His choice of relocation was well made, and under the management of McLoughlin the company's agriculture enterprise was soon a success. In 1825, McLoughlin brought sheep, cattle, hogs, and chickens to Fort Vancouver, and he had his employees plant beans, peas, potatoes, wheat, barley, oats, timothy, and corn. The result was so productive in the first year that a visitor remarked that the apples and vegetables were of "first quality," and he "never saw better wheat." Later additions included goats, turkeys, and pigeons, and nearly all of the varieties of crops then available, namely, beans, turnips, melons, squashes, tomatoes, berries, and fruits. Corn was a disappointment for the HBC and immigrants because it was difficult to grow in the Pacific Northwest's short summer season. By 1828, Simpson complimented the agricultural production at Fort Vancouver by calling it the "... main spring of the business." ${ }^{" 54}$ McLoughlin wrote that by 1828 the fort was self-reliant as to crops, and it was therefore no longer needed to import that basic of all commodities, flour. ${ }^{55}$

\footnotetext{
${ }^{50}$ James R. Gibson, Farming the Frontier: The Agricultural Opening of the Oregon Country, 17861846 (Vancouver, B.C.: University of British Columbia Press, 1985, 14-18, and passim.

${ }^{51}$ Mackie, Richard Somerset, Trading Beyond the Mountains: The British Fur Trade on the Pacific, 1793-1843 (Vancouver: University of British Columbia Press, 1997), 153.

${ }^{52}$ Mackie, 29.

${ }^{53}$ Mackie, 33-34.

${ }^{54}$ Mackie, 18, 29.

${ }^{55}$ S. A. Clarke, Pioneer Days of Oregon History (Portland, Oregon: J.K. Gill Company, 1905), 2: 215.
} 
Mcloughlin was the Oregon Country's first crop researcher. He experimented with different varieties of wheat by first planting seeds in a garden plot in order to find the highest yields. ${ }^{56}$ He built pens for livestock and moved them around in order to ensure his fields were adequately fertilized ${ }^{57}$ By the time Americans began to arrive in the early 1830 s, McLoughlin had already established methods of agriculture that had proven to be successful for Oregon's land and climate. He readily shared this knowledge with immigrants-thus providing them with an important key to survival in an unfamiliar environment.

It was standard practice at Fort Vancouver to plant winter wheat in the fall and harvest it during the following August and September, although spring wheat was also sometimes planted and harvested in the summer months. ${ }^{58}$ Twenty to thirty men with ploughs and teams could plant thirty to forty acres of wheat a day. ${ }^{59} \mathrm{By}$ 1839, there were about 300 men (100 of them Natives) employed at the fort's farms. ${ }^{60}$ Grain was rotated with row crops (corn, potatoes, beans) in order to prevent loss of soil fertility. ${ }^{61}$ Clover, a nitrogen-fixing supplement, was occasionally planted, and soil that was near exhaustion was left fallow for a year or longer. ${ }^{62}$ Seeds were sown by hand and crops were harvested with sickle and

\footnotetext{
${ }^{56}$ T. C. Elliot, ed., "Extracts from the Journal of Lieut. George Foster Emmons" Oregon Historical Quarterly 26 (September 1925): 271.

57 Charles Wilkes, Narrative of the United States Exploring Expedition during the years 1838, 1838, 1840, 1841, 1842, 4: 414.

${ }^{58}$ Nathaniel J. Wyeth, The Journals of Captain Nathaniel J. Wyeth's Expedition to the Oregon Country, 1831-1836, ed. Don Johnson (Ye Galleon Press, 1997), 34.

${ }^{59}$ Thomas Farnham, Travels in the Great Western Prairies, the Anahuac and Rocky Mountains and in the Oregon Territory (New York: Greeley and McElrath, 1843), 98.

60 Farnham, Travels in the Great Western Plains ..., 98.

${ }^{61}$ E. E. Rich, ed., The Letters of John McLoughlin from Fort Vancouver to the Governor and Committee, First Series, 1825-1838 (London, 1941), 205.

${ }^{62}$ E. E. Rich, ed., The Letters of John McLoughlin ...., First Series, 205.
} 
cradle, the grain being threshed in the old custom of letting horses run over it; however, by 1834 , McLoughlin had acquired a horse-drawn thresher. ${ }^{63}$

In 1834, American naturalist John Townsend accompanied American entrepreneur Nathaniel Wyeth on his second journey to Oregon where he visited McLoughlin at Fort Vancouver, and chronicled the visit in his journal. Townsend wrote that during the prior ten years McLoughlin's cattle herd had grown from a handful to about 700 long-horned cattle, and although not good milch producers, they were excellent for beef. ${ }^{64}$ Townsend observed a gristmill and grain thresher, both horse driven, a water-powered sawmill, and "thirty or forty log huts" occupied by Canadians and their families. ${ }^{65}$ The huts were arranged in rows with broad lanes between them, and the entire scene appeared to Townsend as would a small village. ${ }^{66}$

In addition to the development of large farms for cultivation and grazing, McLoughlin developed several smaller plots that lay scattered about the Fort's expansive farmland. Three of the largest farms comprised the heart of the HBC's agricultural domain on the Pacific coast: The nearly 500 acre Fort Plain Farm was adjacent to Fort Vancouver, ${ }^{67}$ The 1,000 -acre Mill Plain Farm was six miles east of the fort and one mile north of the Columbia River; ${ }^{68}$ and the Lower Plain

\footnotetext{
63 John R. Townsend, Narrative of a Journey Across the Rocky Mountains to the Columbia River and a Visit to the Sandwich Islands and Chile with a Scientific Appendix (Philadelphia: Henry Perkins, 1839), 171-172.

${ }^{64}$ Townsend, 173; these were Spanish or "California" Longhorns which were the only breed available in numbers at the time.

${ }^{65}$ Townsend, 171-172.

${ }^{66}$ Townsend, 172; U.S, Navy officer Charles Wilkes, visiting in 1841, would also describe this setting as having the appearance of a village.

67 "British and American Joint Commission for the Settlement of the Claims of the Hudson's Bay and Puget's Sound Agricultural Companies" (Washington D.C., 1865-1869), 66.

68 "British and American Joint Commission," 52.
} 
Farm began three miles west of the fort and included five miles of river frontage ${ }^{69} \mathrm{~A}$ former employee estimated that the three farms, together with the fort and forest/grazing land, amounted to 160,000 acres consisting of twenty-five miles of Columbia River frontage ten miles inland. ${ }^{70}$ A 640 -acre dairy farm on Sauvie's Island at the confluence of the Columbia and Willamette Rivers was also considered part of the Fort Vancouver property. ${ }^{71}$

Although the HBC cultivated only a small fraction of the land it claimed, the Company's argument for legal title to all of it centered on an historic use of the uncultivated property for lumber and grazing. In 1829, there were 120 cultivated acres, and by 1846 the number of cultivated acres had grown to $1,420 .{ }^{72}$ Between 1825 and 1846 the number of cattle at Vancouver grew from 27 to 1,915 , and between 1832 and 1846 the number of sheep rose from 49 to 3,000 ; during this same period, horses increased from 120 to 517, and hogs increased from 29 to $800 .^{73}$

McLoughlin planted his garden and orchard directly behind the fort. It was there, in September 1836, that Presbyterian Missionaries Narcissa and Marcus Whitman visited McLoughlin. Mrs. Whitman later remarked in her diary that Fort Vancouver was "the New York of the Pacific Ocean," and of the garden and orchard she wrote, "Here we find fruit of every description ... and every kind of

\footnotetext{
69 "British and American Joint Commission," 106; Gibson, 36.

70 "British and American Joint Commission," 120-121, 96.

71 "British and American Joint Commission,", 223.

${ }^{72}$ Gibson, 36.

${ }^{73}$ Gibson, 39.
} 
vegetable, too numerous to mention." ${ }^{74}$ Mrs. Whitman's diary, written over eighteen days at the fort, contained a succession of descriptive ebullitions for the beauty of the place and for its sumptuous capacity; the stores were filled from top to bottom with everything needed for comfort, and nearby there was a dairy with cheese and butter.

Agriculture was the largest operation at Fort Vancouver, but there were several other occupations as well. In 1838, twenty-three of the Fort's seventyfour employees were engaged in farming, and the rest were occupied in maintaining and working the stables, granaries, tanning sheds, blacksmith's and cooper's shops, bakery, warehouses, flour mill, two sawmills, an apothecary, and a small fishing endeavor. ${ }^{75}$ The area surrounding the four-acre fort enclosure accommodated many of these various edifices and activities, and, by 1841 , included fifty log houses inhabited by HBC employees and their families.

There were, however, concerns that had wider implications for the Hudson's Bay Company than the care and maintenance of its Fort Vancouver farms. For decades, the HBC had competed with Russian and American fur traders in the Pacific Northwest. Through the 1820s, American ships supplied the Russian post at Sitka with agricultural products and manufactured goods in exchange for furs. Governor Simpson reasoned that if he could usurp the American contract with the Russians, then the HBC would benefit greatly from the diminished competition. Simpson made this proposal in 1829, but the Russians turned him

\footnotetext{
${ }^{74}$ Samuel Christopher Lancaster, Columbia: America's Great Highway (Portland, Oregon, 1915), 30.

${ }^{75}$ Wilkes, Narrative of the United States Exploring Expedition during the years 1838, 1838, 1840, 1841, 1842, 4: 326; Michael Leon Olsen, "The Beginnings of Agriculture in Western Oregon and Western Washington" (Ph.D. diss., University of Washington, 1971), 16; Gibson, 35.
} 
down because they were leery of reliance on a competitor for something as vital as wheat, and worried that the HBC would be unwilling to supply them with textiles. $^{76}$

The next decade, however, brought changes that worked in the HBC's favor. Alta California had long been the Russians' supply mainstay, providing items such as grains, beef, tallow, and lard to their American-Russian Company's one or two annual supply ships. However, the secularization of California's agriculturally productive missions in the mid 1830s precipitated a rapid decline in exportable surpluses, and caused the Russians to reconsider Simpson's offer. ${ }^{77}$ Over the next few years, the two sides continued to wrestle with the consequences of such an alliance, when a political solution emerged shortly after a September 1838 meeting between HBC Governor John Pelly and RussianAmerican Company director Baron Von Wrangell. Pelly iterated Simpson's proposal that his company supply Sitka, therein ridding themselves of American competition and reducing costs for both companies. Amidst yet more wrangling, the tsarist government, in late 1838 , ordered Wrangell to secure a "peaceful agreement" with the HBC. ${ }^{78}$ Effective June 1, 1840, the two companies entered a ten-year contract that included annual HBC shipments of " 8,400 bushels of wheat, eight tons of flour, $6 \frac{1}{2}$ of barley groats, $6 \frac{1}{2}$ tons of peas, 15 tons of salted beef, $1 \frac{1}{2}$ tons of ham, and eight tons of butter. plus sundry manufactures at £13 per ton." ${ }^{79}$

\footnotetext{
${ }^{76}$ Gibson, 77-79.

77 Gibson, 80-81.

${ }^{78}$ Gibson, 82.

${ }^{79}$ Gibson, 83.
} 
In order to meet the demands of this new contract, the HBC needed to expand its agricultural operation. Convinced that farming and fur trapping industries were too disparate to be effectively combined, the HBC, in February 1839, created the Puget's Sound Agricultural Company (PSAC) with Simpson in charge and Mcloughlin as field manager. ${ }^{80}$ As James Gibson has noted, the PSAC was separate in title only, and in effect operated as a "subsidiary" of the HBC's fur trading operation. ${ }^{81}$ The new company quickly set about farming at two locations: Cowlitz near what is now Toledo, Washington, and Nisqually near what is now DuPont, Washington. Cowlitz farm was located about thirty-five miles north from the Columbia River and a mile west from the head of navigation on the Cowlitz River. The farm included about 2,000 acres of cropland and 1,000 acres of grazing land. ${ }^{82}$

There were political considerations behind the HBC's decision in selecting the location for the Cowlitz farm. No boundary decision with the United States had yet been made, and the company governance, realizing that settlement patterns carried weight in such negotiations, favored Cowlitz as a strategic location because of its access to both the Columbia River and the strait of De Fuco. ${ }^{83}$ The HBC also attempted to strengthen its territorial claims by offering shares of farmland in the Puget Sound portage to Company retirees. The attempt failed primarily because better farmland was available in the Willamette Valley where it

\footnotetext{
${ }^{80}$ Gibson, 85-86.

${ }^{81}$ Gibson, 86.

82 "British and American Joint Commission for the Settlement of the Claims of the Hudson's Bay and Puget's Sound Agricultural Companies" ( Washington D.C.: M'Gill and Witherow, 1867), 100. ${ }^{83}$ Gibson, 86-87.
} 
was also free and unencumbered. ${ }^{84}$ For these same reasons, HBC attempts to lure its Willamette Valley retirees to the north side of the Columbia also failed.

Chosen for its large, open plains, the farm at Fort Nisqually lay along the shore of the Puget Sound and embraced an area estimated to be as much as 261 square miles. ${ }^{85}$ Poor quality soil at Nisqually determined its primary use for livestock, while the soil at Cowlitz was suitable for crops. Because both locations were already part of the HBC domain, steps were taken to prepare them for agricultural production before the PSAC was formally established. In the summer of 1838 , McLoughlin had a herd of more than 600 sheep sent by ship to Nisqually from California. ${ }^{86}$ In the spring of 1841 , livestock purchases in California brought 3,200 sheep and 551 cattle to Nisqually; ${ }^{87}$ by 1846 , Nisqually farm tended about 8,000 sheep and 3,000 Spanish (Longhorn) cattle. ${ }^{88}$

Cowlitz farm became the principal supplier of wheat for the Russian contract. Prevalent crops at the farm included: "Spring wheat, barley, oats, winter wheat ... buckwheat, potatoes, turnips, colewort, flax, clover, and Timothy." ${ }^{.99}$ Annual wheat production between 1840 and 1846 fluctuated between 2,500 bushels and 7,000 to 8,000 bushels. Because the Cowlitz wheat harvest fell short of the 8,400 bushels needed to satisfy the Russian contract and left none for domestic consumption, McLoughlin supplied wheat from Vancouver, and purchased wheat from Willamette Valley settlers-on occasion, he also bought wheat from

\footnotetext{
${ }^{84}$ Gibson, 110-111.

85 "British and American Joint Commission for the Settlement of the Claims of the Hudson's Bay and Puget's Sound Agricultural Companies", (Montreal: John Lovell, 1868) 3: 26.

${ }^{86}$ Rich, ed., Letters of John McLoughlin 4: 248-251.

${ }^{87}$ Mackie, 239

${ }^{88}$ Gibson, 97.

${ }^{89}$ Gibson, 93.
} 
California. ${ }^{90}$ Ironically, the Company's annual purchases of surplus wheat benefited the American settlement, but it was at cross-purposes with HBC governance that wanted the settlers out of the valley. ${ }^{91}$

Without a trading outlet for their surplus grain, destitute farmers in the Willamette Valley would have been hard pressed to secure the domestic goods and implements needed to survive. Plows, scythes and cradles, seed, harness, textiles, saws, leather goods, sewing supplies, and cooking utensils are some of the goods that were exchanged for wheat at Fort Vancouver. Robert J. Loewenberg, in Equality on the Oregon Frontier: Jason Lee and the Methodist Mission, 1834-43 (1976), suggests that part of the reason for McLoughlin's readiness to buy and trade for Willamette Valley wheat was because he and others in command feared an American attack should the Company fail to provide a market for the settlement's surpluses. ${ }^{92}$ However, fear seems unlikely to have significantly influenced McLoughlin's behavior toward American settlers because he had a history of applying, in an ad hoc manner, rules and policies that were unfavorable to them; for examples, he created discord by refusing to sell cattle, and he insulted Ewing Young and his men by initially refusing to trade with them. James R. Gibson's analysis gives little credence to fear as a motivating influence for HBC wheat purchases, and leaves little doubt that

\footnotetext{
${ }^{90}$ Gibson, 94.

${ }^{91}$ Robert J. Loewenberg, Equality on the Oregon Frontier: Jason Lee and the Methodist Mission, 1834-43 (Seattle: University of Washington Press, 1976), 175; Gibson, 94-even Simpson recognized the necessity of buying valley wheat.

${ }^{92}$ Loewenberg 174-175,
} 
McLoughlin's principal reasons for buying wheat from American settlers was based on contractual obligations, trade, and speculation. ${ }^{93}$

McLoughlin was also buying Willamette Valley wheat long before the incorporation of the PSAC. In 1836, farmers in the vicinity of French Prairie sold 1,000 bushels of surplus wheat to the HBC. In 1837, valley settlers reportedly produced a surplus of 5,500 bushels, and in 1838 the HBC announced that it was buying the valley settlement's entire wheat surplus. ${ }^{94}$

In early 1837, an unofficial census enumerated thirteen French Canadians and seventeen American settlers living in the Willamette Valley. ${ }^{95}$ The Frenchmen were $\mathrm{HBC}$ retirees, and most of the American population had arrived between 1832 and 1834 with parties led by American entrepreneur Nathaniel Wyeth, Methodist Reverend Jason Lee, and a former fur trapper named Ewing Young. There was little money in the settlement at the time, and payment in wheat was the only way that McLoughlin could recover debts owed to the Company. ${ }^{96}$ Thus, a symbiotic commercial relationship between Willamette Valley farmers and the HBC existed from shortly after the arrival of the first American settlers, and the advent of the PSAC only served to increase the amount of settlers' wheat the Company required. By 1844, McLoughlin estimated that the Willamette Valley would be able to supply at least 20,000 bushels of wheat to Fort Vancouver. ${ }^{97}$

\footnotetext{
${ }_{93}^{93}$ Gibson, 94, 85-108 passim.

${ }_{95}^{94}$ Hussey, 108.

95 Slacum's Report on Oregon," Oregon Historical Quarterly, 13 (June 1912): 210.

${ }^{96}$ Slacum's Report, 210.

97 J. A. Hussey, Champoeg: Place of Transition (Portland, OR: Oregon Historical Society, 1967), 114.
} 
Another twist in the enmeshed world of agricultural commerce and politics occurred between 1840 and 1845 when competition for land developed between the HBC and McLoughlin on one side, and the Methodists and private interests at Oregon City on the other side. At issue were competing claims to commercial property at Oregon City, or, as Loewenberg put it, “... questions of wheat, trade, supply, and milling, as well as political and philosophical matters." ${ }^{98}$ The stage for discord was set In 1828 when Simpson and McLoughlin decided to move the Fort Vancouver sawmill operation to Willamette Falls-construction began in 1829. The project lagged until 1841 , at which time Simpson ordered McLoughlin to complete work on the sawmill and also build a flour mill. These renewed efforts were undertaken in order to secure the HBC's commercial dominance in the settlement and to bolster British influence regarding the yet undecided boundary question. ${ }^{99}$ In 1841, a group of missionaries and settlers under the auspices of the Methodist Mission created the Island Milling Company, and by the following year they constructed a gristmill and a sawmill on Abernethy Island. This small island was adjacent to Oregon City and on land claimed by McLoughlin. ${ }^{100}$ McLoughlin finished the two HBC mills in 1843, and the next year he completed a branch store in response to the establishment of American-owned stores. Pioneer Peter Burnett recounted that in 1844 there were four stores in Oregon

\footnotetext{
${ }^{98}$ Loewenberg, 188.

99 Throckmorton, 38; in 1835, HBC governance gave standing orders to counter in-kind any competitive American enterprise.

${ }^{100}$ Throckmorton, 28.
} 
City $;^{101}$ the stores were owned by Francis Pettygrove, John Couch, the Methodists, and the HBC. ${ }^{102}$

McLoughlin saw duplicity at work in the formation of the milling company: "Above three quarters of the stock ... belongs to the Clerical and Civil Members of the Mission, but to disguise from the public its being a Mission mill, they allowed the remainder of the stock to the settlers, and call it a public mill ...."103 McLoughlin was convinced that the Methodists' real goal was to strengthen their claim to the property against his own claim. As evidence, he reasoned that the best location for the missionaries' mills would have been up the Willamette and nearer the heart of the French Prairie settlement where wheat fields would have been closer to the gristmill. ${ }^{104}$

For Jason Lee, superintendant of the Oregon Methodist Mission, investment in the Island Milling Company was in keeping with his practice of co-mingling commerce and proselytizing. While visiting the King of Hawaii In the spring of 1840, the Regent readily agreed to Lee's proposal that the Mission exchange "flour, fish, beef, \& c., for the products of the Sandwich Islands, consisting of

\footnotetext{
${ }^{101}$ Robbins, William G. Landscapes of Promise: The Oregon Story, 1800-1940 (Seattle: University of Washington Press, 1997), 72.

${ }_{102}$ MacColl, 7-8; Throckmorton, 34, 37-38.

${ }^{103}$ E. E. Rich, ed., The Letters of John Mcloughlin from Fort Vancouver to the Governor and Committee, 3d ser. (Toronto: The Champlain Society, 1943), 228. See also Cornelius J. Brosnan, Jason Lee, Prophet of Oregon (New York: The Macmillan Company, 1932), 268; Lee was offered the opportunity to invest in the Island Milling Company but refused. See also Frederick Van Voorhies Holman, Dr. John McLoughlin, the Father of Oregon (Cleveland: Arthur H. Clark Company, 1907), 114-116; Reverend Alvin Waller was the principal architect of the Island Milling company

${ }^{104}$ Bancroft, 1: 297, note 6; the Methodists referred to Oregon City as "the Falls" in an attempt to negate any title McLoughlin might receive for having named it Oregon City in 1842.
} 


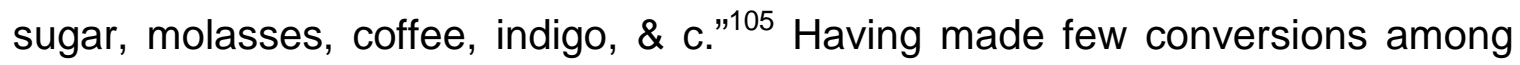
the Indians, Lee came to accept that Methodism and Native lifeways were incompatible. ${ }^{106} \mathrm{He}$ began to focus on administering the Gospel within the rapidly expanding settlement community, and he viewed commerce as a means of maintaining secular as well as spiritual influence; ${ }^{107}$ besides, his mission was deeply in debt to the HBC, and his board of managers had been deprecating his performance while turning a deaf ear to his many requests for money.

Although Simpson had approved completion of the mills, he began to regret his investment because it appeared unlikely that Britain would hold the territory they were built upon. In 1845 , just as the company was contemplating how to divest itself of the mills, McLoughlin stepped in and offered to buy them with his own money. HBC officials, planning to demote McLoughlin and transfer him to a distant post, accepted the Chief Factor's offer and then apprised him of the changes in his status. The situation compelled McLoughlin to resign in 1846, in part because he wanted to remain in Oregon in order to protect his new investments. $^{108}$

Simpson, now shorn of property and purpose south of the Columbia, elected to gradually curtail the amount of wheat the company had been buying from the settlement-limiting the amount to that needed for the Russian contract and for provisioning a few British navy ships. Had Simpson's new guidelines been in

105 Gustavus Hines, Life on the plains of the Pacific. Oregon: its history, condition, and prospects ... embracing extended notes of a voyage around the world (George Derby and Company, 1851), 80.

${ }^{106}$ Loewenberg, 183-193 passim.

107 Throckmorton, 19; Loewenberg, 83.

${ }^{108}$ Throckmorton, 51, 31-51 passim. Political and personal discord between McLoughlin and Simpson and between McLoughlin and the HBC hierarchy also played into his decision to resign. 
effect before the 1845 summer harvest, most of the 6,000 barrels of flour $(30,000$ bushels of wheat) that McLoughlin had in storage for speculative resale in Hawaii would not have been purchased that year from Willamette Valley farms. ${ }^{109}$ Regarding the impact on wheat sales to the settlement, in 1845 McLoughlin bought 20,000 to 26,000 bushels, and in 1846 the HBC bought only 12,000 bushels. ${ }^{110}$ With these limitations firmly in place, the HBC helped set the stage for the formation of the Willamette Valley farmers' cooperative (OPEIC) in the winter of 1847 . The 1846 harvest added to already overflowing granaries, and the OPEIC was created to seek alternative export outlets (This subject is discussed in more detail in the following chapter). ${ }^{111}$

With such an abundance of the necessities for survival in an isolated frontier, McLoughlin had been in a good position to aid the settlers as they began to arrive overland in the early 1830s. Had he been less a benevolent and compassionate man, the immigrants would have had a far worse time of it. As recalled Willard $\mathrm{H}$. Rees, pioneer of $1844::^{112}$

Dr. John McLoughlin, the notable philanthropist of the wilderness, without whose assistance and protecting care none of those first agricultural settlements of the Territory could have been commenced nor successfully maintained. He furnished from the farms, the shops and store houses at Vancouver, teams, cows, hogs, plows, poultry, arms and ammunition, in brief, all the necessary Implements and supplies, or such as he had, mostly

\footnotetext{
${ }^{109}$ Throckmorton, 46. Oregon Spectator, April 18, 1850: Five bushels of wheat went into making one barrel of flour.

${ }_{110}$ Gibson, 142.

${ }^{111}$ Neil M. Howison, Oregon, A Report (Fairfield, Washington: Ye Galleon press, 1967), 22. U.S. Navy Lt. Howison reported the overflowing granaries during a visit to the Willamette Valley in the summer of 1846.

112 "Annual Address," in Transactions of the Oregon Pioneer Association, (Portland, OR: A. Anderson and Company,1882): 29; for a short bio on Willard Rees. See Horace S. Lyman, History of Oregon: The Growth of an American State (New York: North Pacific Publishing Society, 1903), 376.
} 
imported from England, sufficient to enable the pioneer settlers to establish themselves in the occupation of husbandmen, at the same giving them a remunerative market for their produce.

As many an impoverished American immigrant would discover, a combination of events, characters, and conditions manifested by the HBC were of enormous help in their transition to self-subsistence. Henry Warre and Mervyn Vavasour, two British engineering officers, commissioned to report on the feasibility of establishing military stations in the Pacific Northwest, inspected the Oregon Country in 1845. In their report, they expressed an opinion that without the assistance of the HBC there would likely have been less than eighty American families in the settlement (Joe Meek's 1845 census counted just over 2,000 people, most of them Americans). ${ }^{113}$ George Simpson was also an inadvertent aid to American settlement. His decision to move to Vancouver had been difficult to make. Had there been means other than agriculture to lessen the cost of provisioning the Columbia District, or had Simpson been a less inspired and competent man, then the move to Fort Vancouver likely would not have happened. Given the opinion of most fur traders that farming and trapping did not mix well, Simpson also had to consider an unquantifiable cultural discord that loomed over the enterprise.

Even McLoughlin stated that he would have been against farming the Oregon country had it not been for the cost of shipping flour from Europe and the risk of its ruin (although he was also concerned lest his agency become overly

${ }^{113}$ Gibson, 146; for the 1845 census see Bowen, 12-13, and W. D. Fenton, "The Winning of the Oregon Country," Oregon Historical Quarterly 6 (December 1905) 360. 
dependent on Indigenous people for provisions). ${ }^{114}$ But McLoughlin was an experienced farmer, having grown up on his French Canadian father's farm in the St. Lawrence River Valley, and he rose assiduously to his task. ${ }^{115}$ For the immediate future of the American immigrant, then, McLoughlin's humanity was an augmentation in a series of fortuitous developments by the HBC in its Columbia District.

\section{American Settlement}

Agricultural settlement began in the Willamette Valley in the late 1820s when several retired French-Canadian HBC trappers and their Indian families established farms on French Prairie, an open plain just south of Oregon City between the Willamette and Pudding Rivers. ${ }^{116}$ These earliest settlers were drawn to French Prairie because it was open, fertile, arable, and at several locations the land lay unobstructed to the river's edge.$^{117}$ Early Willamette Valley settlement generally followed a pattern of choosing land along the river, but later settlers preferred higher ground inland because several floods had washed out buildings and crops. ${ }^{118}$ According to an immigrant of 1843 , the fertility of the soil in the Willamette Valley was equal or superior to anywhere else in the United States. ${ }^{119}$

Although the subject has not been thoroughly researched, the Panic of 1837

\footnotetext{
${ }^{114}$ Mackie, 153.

${ }^{115}$ Mackie, 152-153.

${ }^{116}$ Gibson, 130.

117 "Copy of a Document Found among the Private Papers of the Late Dr. John McLoughlin," TOPA (1880): 49; Hussey, 56-58.

${ }_{118}^{118}$ Bowen, 62-63.

119 "Letter of M. M. McCarver to Hon. A.C. Dodge, Delegate to Congress," Oregon Historical Quarterly 4 (March 1903): 79.
} 
is consistently referenced in the historiography as one of the primary motivations for the waves of Oregon immigrants beginning in the early 1840 s. ${ }^{120}$ The aggregate of emigration causes are somewhat peripheral concerns for this paper, but agrarian emigrants who came to Oregon in order to better their economic conditions represent the central cast for this paper's theme-the pursuit of commerce and its effect on agricultural development. Farmers' experiences and the dreams they pursued before emigrating to Oregon help to explain how they adapted to their new frontier environment and what choices they made about commerce. By itself, the subject demands a separate study. At minimum, it should be recognized that farmers who emigrated from the Midwest, or what Jesse Douglas called the "Crucible in which the population of the Pacific Northwest was molded,"121 expended their greatest adaptive energies in coping with a new climate and the pre-territorial economic ascendancy of the Hudson's Bay Company.

Although it was not a seamless transition, life did not change much for most farmers when they immigrated to Oregon. Common experiences for Midwest farmers included: an irregular economy; ${ }^{122}$ wheat as the principal staple; ${ }^{123} \mathrm{a}$

\footnotetext{
${ }^{120}$ Ray Allen Billington, The Far Western Frontier, 1830-1860 (New York: Harper, 1956), 69; Billington cites the Panic of 1837 as a major cause for Midwest immigration to Oregon. Walter Carleton Woodward, The Rise and Early History of Political Parties in Oregon 1843-1868 (Portland, Oregon, J. K. Gill Company, 1913), 4-5; Bowen, 18.

${ }_{21}$ Jesse Douglas, "Origins of the Population of Oregon in 1850," Pacific Historical Review 41 (1950), 108.

${ }_{22}$ Harvey L. Carter, "Rural Indiana in Transition, 1850-1860," Agricultural History 20 (April 1946): 112-113.

${ }^{123}$ James Christy Bell, Jr., Opening a Highway to the Pacific 1838-1846 (New York: Longmans, Green and Company, 1921), 123.
} 
nearly universal system of bad roads; $^{124}$ bartering farm goods for merchandize; ${ }^{125}$ and the centrality of economic gain. ${ }^{126}$ Near Chicago in 1847 , the Prairie Farmer described local roads as "... the same roads we knew years ago .... The same deep and hoary looking mud holes-the same rich hippopotami lounges-the same mixture of sticks and fathomless dirt. ${ }^{127} \operatorname{In} 1842$, Dr. E. Duis of McLean County, Illinois described the economy as "... frightful, worse than has since ever been known;"128 Judge McLune, Duis' fellow McLean County resident, stated that "Failures were an hourly occurrence. My pork could not be sold to even realize the cost of transportation." ${ }^{129}$ From the late 1830 s to the early 1840 s the bottom fell out of the agricultural market in the Mississippi Valley. In January 1839 , Cincinnati flour sold for $\$ 6.25$, and in October 1842 , it sold for $\$ 2.51 .^{130}$ Gauged by these rough experiences, Midwestern farmers were not likely to be overly distressed by conditions in Oregon.

Champoeg, located on French Prairie twenty-one miles south of Oregon City, was popular with $\mathrm{HBC}$ retirees because it was a natural landing place for loading and offloading river craft. While visiting French Prairie in 1832, New England entrepreneur Nathaniel Wyeth commented that Champoeg would be the natural place to begin colonizing the Oregon Country. ${ }^{131}$ Rather than a singularly observable location, Champoeg was described anywhere along a five-mile

\footnotetext{
${ }^{124}$ Bell, 123 . Frontier roads before 1850 were generally in poor condition during rainy seasons. See also The Prairie Farmer 7 (1847): 136, 149.

${ }^{125}$ Danhof, 29-31.

${ }^{126}$ Danhof, 16.

127 Prairie Farmer, 281.

${ }^{128}$ Dr. E. Duis, The Good Old Times in McLean County, Illinois, Containing Two Hundred and Sixty One Sketches of Old Settlers (Bloomington: The Leader, 1872), 14-15.

${ }^{129}$ Dr. E. Duis, 15; .

${ }^{130}$ Bell, 124.

${ }^{131}$ Hussey, 57.
} 
stretch of river bank with many accessible landing spots. Other favorable features included open plains to the river, and a slow current-upriver from here the river began to meander and the current became stronger. ${ }^{132}$

Until the introduction of steamboats in 1850, Champoeg remained the head of navigation in the Willamette Valley. ${ }^{133}$ McLoughlin believed Champoeg would eventually overtake Oregon City as the valley's leading trade center, and he was not alone in his belief. Ex-fur trapper and entrepreneur Robert Newell and Portland Merchant Francis Pettygrove also saw a healthy economic future for Champoeg. Pettygrove, merchant and co-founder of Portland, owned a granary and warehouse at Champoeg between 1844 and 1848 where he traded supplies to farmers for their agricultural products, bringing in between $\$ 12,000$ and $\$ 15,000$ a year. ${ }^{134}$ Over the winter of $1843-1844$, Newell staked a claim at Champoeg and, by 1845 , he began dividing his property into lots with the intent of establishing a town. ${ }^{135}$ Apparently, his town building enterprise was not successful enough because, in 1846, Newell was in the riverboat business transporting passengers, agricultural products, and sundries between Oregon City and Champoeg. ${ }^{136}$ Newell next opened a warehouse and trading store at Champoeg, taking in Willamette Valley wheat for transport and in exchange for “flour, feed, ham 'pickled pork' (bacon) and such staples." ${ }^{137}$ Newell continued to operate his store until the flood of 1861-1862 when the town's buildings were

\footnotetext{
${ }^{132}$ Hussey, 56-51.

${ }^{133}$ Corning, $77-89$ passim.

${ }^{134}$ Hussey, 198.

${ }^{135}$ Hussey, 195-198.

${ }^{136}$ Oregon Spectator, April 30, 1846; here, Newell advertises two "fast running" man powered boats for passage between Oregon City and Champoeg.

${ }^{137}$ T.C. Elliott "Doctor Robert Newell: Pioneer," Oregon Historical Quarterly 9 (June 1908): 119.
} 
washed away. Newell sold his Champoeg property shortly after the flood and other Champoeg residents moved to higher ground inland about one-half mile. The landing site was too convenient to forsake, however, and farmers continued to use Champoeg as a major shipping point through the 1860 s. $^{138}$

In 1900, eighty-two-year-old Louis Labonté II provided historians with the only recorded eye witness account of Oregon's first agricultural community-the French-Indian settlers of French Prairie. ${ }^{139}$ In 1831, Louis Labonté I., a French Canadian who had recently retired from the HBC, brought his family to French Prairie. His wife was the daughter of Chief Kobayway of the Clatsop tribe, and his son, Louis II, was then about thirteen years old. The younger Louis recalled that Joseph Gervais was the first to establish a farm, settling on ground at Chemaway, about twelve miles south of Champoeg. Labonté I did not establish a working farm, but instead moved near Gervais and helped him to raise wheat and improve the property. ${ }^{140}$ Labonté II identified six retired HBC employees who comprised the community of Oregon's earliest settlers between the years 18281832: ${ }^{141}$ Joseph Gervais; Etienne Lucier; Louis Labonté I; William Cannon; Alexander Carson; and Dubruy [Jean Baptiste Dubreuil]. Louis Labonté II, however, did not mention Jean Desportes Baptiste McKay, a French-Indian HBC retiree who also settled at Champoeg about 1831. Desportes' claim, located west

\footnotetext{
${ }^{138}$ Hussey, 232-233.

139 Louis Labonté, "Reminiscences of Louis Labonté," interview by Horace S. Lyman, Oregon Historical Quarterly 1 (March-December, 1900): 169-188.

${ }^{140}$ Louis Labonté, "Reminiscences," 172-173.

${ }^{141}$ Louis Labonte, "Reminiscences," 173; "Copy of a Document Found among the Private Papers of the Late Dr. John McLoughlin," in TOPA (1880): 48-49. Here, McLoughlin suggests that Lucier was the first to settle, but this has been a long debated subject that will likely never be conclusively settled.
} 
of Champoeg, was the principal "point of entry into French Prairie and served as a landing and shipping point for incoming supplies and outgoing wheat."142 Surplus wheat was usually transported to Vancouver by canoe.

The first Americans began to arrive in 1832. Nathaniel Wyeth, a Bostonian bent on making money in agriculture and trapping, organized a crew of twentyfour men and headed to Oregon where he planned to enter commercial competition with the HBC. However, the venture met with many obstacles and Wyeth was forced to return to Boston in 1833. Before heading back east, Wyeth recorded his observations of the livestock, garden vegetables, and wheat then in possession of the French-Canadian farmers on French Prairie: ${ }^{143}$

22 mils [south] from the falls are 3 or 4 Canadians settled as farmers. They have now been there one year have Hogs, Horses, Cows, have built barns, houses, and raised wheat, barley, potatoes, turnips, cabages, corn, punkins, mellons ...

In 1834, Wyeth tried again to establish a business in Oregon. He corresponded that he had established a farm on Sauvie Island (Fort William), and that he had "commenced" a farm about forty miles from the mouth of the Willamette on a "beautiful prairie" (French Prairie). ${ }^{144}$ Wyeth's journal entries and

\footnotetext{
${ }^{142}$ Lou Ann Speulda, Champoeg: A Perspective of a Frontier Community in Oregon, 1830-1861 (Corvallis: Department of Anthropology, Oregon State University, 1988), 10; Bancroft, History of Oregon, 1: 77. See also William A. Slacum, "Slacum's Report on Oregon," Oregon Historical Quarterly 13 (June 1912): 192-193. Slacum refers to McKay as "Jean Baptiste Deshortez McRoy," and states that he was the first settler in the Valley. But McKay was almost certainly not the first settler. See also Nathaniel J. Wyeth, The Correspondence and Journals of Captain Nathaniel J. Wyeth, 1831-1836, ed. F. G. Young (Sources of the History of Oregon, Vol. 1, Eugene, Oregon: University Press, 1899), 179, in which Wyeth, in the late months of 1832, writes that there are about nine settlers on the Willamette River.

${ }^{143}$ Nathaniel J. Wyeth, Correspondence and Journals of Captain Nathaniel J. Wyeth, 1831-36, 144-147, 179, 233, 250-251.

${ }^{144}$ Nathaniel Wyeth, The Correspondence and journals of Captain Nathaniel Wyeth, 1831-36, 145; Gibson, 131-132; Dorothy O. Johansen And Charles M. Gates, Empire of the Columbia: A History of the Pacific Northwest ( New York: Harper and Row, 1967), 144-147.
} 
correspondence appear to be the only evidence that he worked this latter farm. On September 26, 1834, Wyeth sent three men with some agricultural implements to the valley farm, and in a letter later published in the Oregon Spectator, he wrote that he had "planted wheat on the Willamette and on Wapato Island. ${ }^{145}$ In February, he visited the Willamette farm and noted that only two men remained there. ${ }^{146}$ By 1836 , Wyeth's second attempt at establishing an Oregon enterprise had failed. He wrote that several setbacks had left him bereft of supplies, money, and men. ${ }^{147}$

Wyeth left his encampment at Fort William well supplied with "cattle, sheep, goats, \& hogs," as well as "wheat, corn, potatoes, peas, beans, turnips, grafted and planted apples, and other fruits." 148 He sold most of this inventory to the HBC, and left one of his hired men, Courtney Walker, in charge of Fort William with instructions to "lease it to some trustworthy person unless sooner reclaimed."149 Walker apparently abandoned it soon after Wyeth left, and Mcloughlin had it torn down. Although Wyeth was unsuccessful, at least seven of the men from his second expedition bolstered the American community by settling in the Willamette Valley, and the conveyance and disbursal of his

${ }^{145}$ Nathaniel J. Wyeth, Correspondence and Journals of Captain Nathaniel J. Wyeth, 1831-36, 234, and Oregon Spectator, April 3, 1851. See also J. A. Hussey, Champoeg: Place of Transition (Portland, OR: Oregon Historical Society, 1967), 60, 70; Hussey notes that the location of Wyeth's farm can only be approximated to be "in the general region of Champoeg Creek," French Prairie.

${ }^{146}$ Nathaniel J. Wyeth, Correspondence and Journals of Captain Nathaniel J. Wyeth, 1831-36, 250-251. Johansen and Gates, 147, notes that Wyeth left his farm to a tenant, "James O'Neill;" however, the note is not given a citation and I have not been able to find the source. Wyeth mentions an O'Neal or O'Neal on p. 205 of his Correspondence ... but nothing regarding the farm.

${ }_{147}^{14}$ Johansen and Gates, 148-150.

${ }^{148}$ Nathaniel J. Wyeth, Correspondence and Journals of Captain Nathaniel J. Wyeth, 1831-36, 255.

${ }^{149}$ Mackie, 100. 
substantial inventory somewhat alleviated the immigrants' dependency on the HBC for supplies. ${ }^{150}$

In 1833, John Ball became likely the first American to settle in the Willamette Valley. ${ }^{151}$ An original member of Wyeth's first attempt to compete commercially with the HBC, Ball decided to stay and try farming on French Prairie. Although he lasted only one year, Ball mentions in his journal that he planted wheat from the twenty-five bushels given to him by Dr. McLoughlin, but that his corn and potatoes did not survive for lack of rain. ${ }^{152}$ Ball was initially encouraged by the agricultural potential of the valley, but he began to wonder if the area would attract enough settlers to form a viable society. After much loneliness and intermittent attacks of "fever and ague," he sold his produce to the HBC and, with regret, left the Oregon country for good. ${ }^{153}$

In 1835, Joseph Gervais and Wesley Hauxhurst, an American, each built a gristmill on French Prairie. Gervais is said to have built his mill on property he settled at Mill Creek and evidence for the location of Hauxhurst's mill suggests that it was built on McKay's property at Champoeg Creek. ${ }^{154}$ Between 1841 and

\footnotetext{
${ }_{151}^{150}$ Hussey, 71.

151 The Oregon Spectator, on April 3, 1851, published part of a series of letters between John McLoughlin, Nathaniel Wyeth, and Territorial Delegate Samuel Thurston; among the letters, Wyeth states that John Ball was the first American to plant wheat in Oregon.

152 John Ball, "Across the Continent Seventy Years Ago," Kate Ball Powers, ed., Oregon Historical Quarterly 3 (March-December 1902): 103.

${ }^{153}$ John Ball, "Across the Continent"; fever or ague was a common description of an epidemic that befell the lower Columbia River and Willamette Valley annually from 1830 to 1834 . Most studies have concluded that the disease was malaria; one of the best sources for the argument is an article by Robert T. Boyd. "Another Look at the 'Fever and Ague' of Western Oregon," Ethnohistory 22 (Spring 1975), 135-154. Although spread across racial lines, native people were decimated by it—Boyd (p. 135) estimated only 2,100 Indians survived from a pre-epidemic population of 32,000 .

${ }^{154}$ Thomas Vaughn and Martin Wrinch, "Joseph Gervais a Familiar Mystery Man," Oregon Historical Quarterly 66 (December 1965) 43; See also the Oregonian, March 19, 1893, and Hussy, 74-75.
} 
1843, the HBC built a granary at Champoeg from where the company accepted the settlers' wheat. Before then, the valley farmers had to take their wheat by canoe to Fort Vancouver-a trip that included an arduous one-fourth mile portage around the falls at Oregon City. ${ }^{155}$

On September 15, 1834, Reverend Jason Lee and four other Methodist missionary personnel arrived at Fort Vancouver, having accompanied Wyeth on his 1834 return trip. ${ }^{156}$ In addition to Reverend Lee, the group included his nephew, Daniel Lee, Courtney Walker, P. L. Edwards, and Cyrus Shepard. ${ }^{157}$ At first, Lee wanted to settle in the Flathead country east of the Cascades, but McLoughlin convinced him to settle at French Prairie where his people could more safely conduct their work. ${ }^{158}$ In October, the missionaries chose a site on the west side of the Willamette, ten miles north of Salem and sixty miles from the river's confluence with the Columbia. ${ }^{159}$ In the spring, they began farming, producing in that first year (1835) a variety of crops for which the number of bushels are known: Wheat 150; oats 35 ; barley 56 ; peas 87 ; potatoes 250 . In 1836, the Mission's crop production more than doubled. ${ }^{160}$

Earlier, when Lee and his entourage arrived at the HBC's Fort Walla Walla, he had to confront the problem of transporting ten horses, four mules, and three cows aboard a barge Wyeth planned to take down the Columbia to The Dalles.

\footnotetext{
${ }^{155}$ Hussey, 107-108; Nathaniel J. Wyeth, Correspondence and Journals of Captain Nathaniel J. Wyeth, 1831-36, 178.

${ }^{156}$ Cornelius J. Brosnan, Jason Lee, Prophet of Oregon (New York: The Macmillan Company, 1932), 69.

${ }^{157}$ Brosnan, 38, 46.

${ }^{158}$ Brosnan, 71.

${ }^{159}$ Brosnan, 70-71.

160 Slacum, "Report." 194.
} 
Chief Clerk Pierre C. Pambrum solved the problem by offering to exchange the animals for supplies and a promise of replacement livestock at Fort Vancouver. ${ }^{161}$ Daniel Lee later wrote that the missionaries obtained horses at Fort Vancouver to replace those left at Walla Walla, and that McLoughlin sent eight oxen and ten cows to the Mission sometime in early October. ${ }^{162}$ It is not known exactly how many head of these cattle belonged to the Mission, but at least until 1837 the Methodists held title to the only independently owned cattle in the Northwest. ${ }^{163}$

\footnotetext{
${ }^{161}$ Brosnan, 68; Bancroft, History of Oregon, 1: 35, 65.

162 Daniel Lee and J. H. Frost, Ten Years in Oregon (New York: Published for the Authors, 1844), 126; Lee wrote the first half of this 344 page book.

${ }^{163}$ Oregon Spectator, May 14, 1846.
} 


\section{CHAPTER TWO}

\section{OREGON'S FIRST FARM COOPERATIVES: WILLAMETTE CATTLE}

COMPANY (WCC ), JOSEPH GALE VENTURE, AND THE OREGON

PRODUCERS' EXPORTING AND IMPORTING COMPANY (OPEIC)

\section{Willamette Cattle Company}

In 1834, a group of sixteen men, led by a fur trapper named Ewing Young, entered Oregon Country overland from California. Young had been lured to Oregon by the descriptions of Hall J. Kelly, an early advocate for settlement in Oregon. Although Young had planned an eventual return to California, he became impressed with the Chehalem Valley, and he and several of his men decided to stay and try their hand at farming. ${ }^{164}$ With his herd of seventy-seven horses, Young immediately became one the area's wealthiest settlers and would have been even more wealthy had he secured clear title to the fifty-square-mile ranch he originally claimed. ${ }^{165}$

Young was different from the tenured settlers on French Prairie in that he did not focus on growing wheat, at that time the settlement's only marketable product. He wanted to be independent from the $\mathrm{HBC}$, and he and his men endeavored to achieve that end. ${ }^{166}$ However, his desire for independence was also influenced by McLoughlin's initial refusal to trade with him. McLoughlin had received a letter accusing Young's band of stealing horses, an accusation that the Chief Factor at first accepted verbatim. The discord was eventually resolved

\footnotetext{
${ }^{164}$ Kenneth L. Holmes, Ewing Young: Master Trapper (Portland, Oregon: Binfords \& Mort,1967), 103-111.

${ }^{165}$ Holmes, 110.

${ }^{166}$ Loewenberg, 173; Holmes, 111.
} 
peacefully after McLoughlin obtained evidence that Young was likely innocent of the charge.

Oregon population counts before the 1850 federal census are rudimentary, but at the beginning of 1837 it is likely that the most accurate count of the white male settler population in the Willamette Valley was enumerated by U.S. Navy Lt. William A. Slacum who had been sent to Oregon by President Jackson to report on the state of the country. Slacum arrived in Oregon on December 22, 1836, and during his nearly two-month stay he counted thirty settlers, including thirteen retired HBC employees (French Canadians) and seventeen Americans. ${ }^{167}$ Historian James Gibson provides evidence for eighteen French Canadian settlers in $1836 .{ }^{168}$ Lt. Slacum's count was from January 1837 and did not include five Methodist missionaries then stationed in the Willamette Valley.

Lt. Slacum was a purser and his training is affirmed in the detail of his report to Congress, dated December 18,1837 . His inventory of 16 farms revealed that each farm averaged 38 acres of cultivated land, 27 hogs, 15 horses, and annual wheat harvest yields of 486 bushels. ${ }^{169}$ Per farm production also included enough Barley, oats, peas, and potatoes for domestic consumption. Slacum estimated the settlement could furnish 5,500 bushels of surplus wheat that could then be sold to the HBC for fifty cents a bushel. ${ }^{170}$ McLoughlin typically accepted wheat in exchange for supplies, and recorded the accrual of debts and credits.

\footnotetext{
${ }^{167}$ Slacum, "Report," Oregon Historical Quarterly 13 (June 1912): 210.

${ }^{168}$ Gibson, 131-132.

169 Slacum, "Report," 210. Enumerations are rounded to the nearest whole number. Without Ewing Young's seventy-nine horses, the average number of horses for the remaining fifteen farms would have been ten.

${ }^{170}$ Slacum, "Report," Oregon Historical Quarterly 13 (June 1912): 197-198.
} 
By January 1837, McLoughlin's policy of leasing only two head of cattle to each settler had become a source of increasing disenchantment to those who longed to build their own herds. At the time, the number of livestock at Fort Vancouver included over 600 head of cattle-a number that likely helped fuel the settlers' resentment. ${ }^{171}$ McLoughlin often stretched company rules to accommodate the immigrants, but he was nonetheless beholden to his employer and there were limitations to his largesse beyond which his tenure lay in jeopardy. In a letter found several years after his death in 1857, McLoughlin wrote, "If I sold [cattle] they would of course be entitled to the increase, and I would not have the means to assist the new settlers, and the settlement would be retarded ...."172 This sentiment, however, obscures the pressure McLoughlin was under from HBC officials who believed that he was too generous to the Americans. Unlike the French Canadian HBC retirees, American settlers owed no particular allegiance to McLoughlin and they began to plan ways to circumvent his embargo. ${ }^{173}$

It is uncertain whose original plan it was to organize a company for the purpose of buying cattle in California and driving them overland to the Willamette Valley, but the idea itself had been a subject of discussion among the American

\footnotetext{
${ }^{171}$ For numbers of HBC cattle, see Gibson, 39, and Slacum, "Report," Oregon Historical Quarterly 13 (June 1912): 202.

172 "Copy of a Document Found among the Private Papers of the Late Dr. John McLoughlin," TOPA (1880): 51.

${ }^{173}$ F. G. Young, "Ewing Young and his estate: A Chapter in the Economic and Community Development of Oregon," Oregon Historical Quarterly 21 (September 1920): 174; here, the author notes the authority of the HBC over its retired employees.
} 
settlers before Slacum's arrival. ${ }^{174}$ At least six settlers who became members of the Willamette Cattle Company (WCC) were experienced in herding livestock from California to Oregon. ${ }^{175}$ The Methodist mission was also involved, but it is not clear that mission personnel were privy to the settlers' plans or debates until a few days before the WCC came to fruition on January 13,1837 .

In a letter dated January 10, 1837, Jason Lee wrote, "Went to the lower part of our settlement to meet Wm. A. Slacum, an officer in the United States Navy, and Government agent. I went with him to the houses of all the settlers, and introduced him at the Mission House."176 That same day, Slacum offered free passage on board his ship the Loriot to any men who wished to travel to California for the purpose of buying cattle and returning with them to the Willamette Valley. During a meeting at the mission house, eleven settlers signed on to the WCC, including two French Canadians (Pierre Depot and Amable Arcouette). WCC members chose Young to lead the expedition. ${ }^{177}$

Slacum learned of the settlement's need for cattle when he first met Methodist Reverend Jason Lee and the settlers on January 10, 1837: "In the course of conversation with Mr. Lee, [Ewing] Young, and other settlers, I found that nothing

\footnotetext{
${ }^{174}$ Lee and Frost, Ten Years in Oregon, 144-145; here the author notes that plans for a cattlebuying expedition to California was underway before Slacum arrived in Oregon. See also Courtney Walker, "Sketch of Ewing Young," TOPA (1875): 49-50; Walker states that it was Young and Slacum who together came up with the plan for the WCC.

${ }^{175}$ Holmes, 97; Slacum, "Report," 209. Two WCC men who were with Young's California to Oregon livestock drive in 1834 were Lawrence Carmichael and Webley Hauxhurst; J. W. Nesmith, "A Biographical Sketch of George Gay," TOPA (1882): 88; WCC members George Gay, John Turner, and William J. Bailey were in a group that herded horses from California in 1835.

${ }^{176}$ Reverend A, Atwood, American Settlement of the Oregon Country: Embracing Facts in the Life and Work of Reverend Jason Lee (Tacoma: Washington State Historical Society, 1907), 48.

${ }^{177}$ For a list of WCC members see Slacum, "Report," Oregon Historical Quarterly 13 (June 1912): 209.
} 
was wanting to insure comfort, wealth, and every happiness to the people of this most beautiful country but the possession of neat cattle...."178

Jason Lee invested about $\$ 500$ in the WCC. ${ }^{179}$ McLoughlin invested $\$ 558$ of his own money in the WCC, and two of his subordinate but higher echelon employees, Chief Traders James Douglas and Duncan Finlayson, together invested $\$ 300 .^{180}$ Other cash pledges increased the total amount for the purchase of cattle to $\$ 2500 .{ }^{181}$ That HBC employees as well as two FrenchCanadian retirees invested money in the venture demonstrates that interest in economic gain dominated whatever political convictions the men may have held vis à vis the issue of sovereignty. ${ }^{182}$ In any case, French-Canadian farmers in the Willamette Valley had been aware from their first settlement that the United States would likely prevail south of the Columbia. ${ }^{183}$ Thus, concern for the legitimacy of their land claims and for the future of their families impelled many of them to take sides with the Americans, as attested when, in 1838, nine FrenchCanadians signed a document memorializing the United States Congress to

\footnotetext{
${ }^{178}$ Slacum, "Report," Oregon Historical Quarterly 13 (June 1912): 196. "Neat cattle" were simply cattle as we know them today. Historically, "cattle" meant any livestock to include horses, goats, hogs, and sheep. To distinguish bovines, or, as the one source described, "animals of the ox kind," they were called "neat cattle;" see "Cases Determined in the Supreme Court of Washington," Washington Reports, volume 110, (February 8-April 7, 1920): 436.

179 William I. Marshal, Acquisition of Oregon and the Long Suppressed Evidence About Marcus Whitman (Seattle: Loman and Hanford, 1911), 197. For evidence that suggests both Lee and McLoughlin conspired to assist the WCC in order to dissuade Young from continuing his distillery operation, see Ten Years in Oregon: Travels and Adventures of Doctor E. White and Lady (Ithaca, New York: Mack, Andrus and Company, 1848), 78-79; Doctor White recounts discussions between Lee and McLoughlin about the bad effects of Young's distillery, and notes that McLoughlin relayed these concerns to Young prior to the formation of the WCC.

${ }^{180}$ F. G. Young, "Ewing Young and his estate: A Chapter in the Economic and Community Development of Oregon," Oregon Historical Quarterly 21 (September 1920): 209.

181 Ibid, 208-209.

${ }^{182}$ For a roster of the WCC, see Holmes, 120.

${ }^{183}$ Hussey, 132: notes here that McLoughlin informed the first retirees who settled in the valley that America would likely prevail south of the Columbia.
} 
extend jurisdiction over Oregon. ${ }^{184}$ That Jason Lee and his Methodist acolytes engaged in the secular affairs of commerce is well established in the historiography. As previously mentioned, Lee and mission Steward George Abernethy competed with the $\mathrm{HBC}$ for economic and political influence in the settlement by arranging to have a sawmill, a gristmill, and a store built at the falls. ${ }^{185}$

The eleven members of the WCC set out aboard Slacum's brig on January 21,1837 , but due to difficulties the ship did not cross the Columbia River bar until February 10. One of the Americans disembarked near Vancouver and returned to the Willamette Valley, but left his investment with the company. ${ }^{186}$ The Loriot arrived at Fort Ross, north of Bodega Bay, on February 20. Slacum noted that several Americans approached Young and offered to include their own cattle if Young would permit them to join his return party to Oregon. As a result, seven additional men joined the party.

By early June, Young had succeeded in buying 700 head of Mexican Longhorns and had begun the trail ride back to Oregon; this breed of cattle (sometimes called Spanish cattle) was wild and notoriously difficult to herd. ${ }^{187}$ By June 25, the men had reached central California's San Joaquin River. Due to difficulty in fording the river, the company did not reach the other side until July

\footnotetext{
${ }^{184}$ Hussey, 134. See also Melinda Marie Jetté, “We Have Almost Every Religion but our own,” Oregon Historical Quarterly 108 (Summer 2007): 99-118 passim; Jetté notes the independence of French-Canadian settlers who appeared more interested in their families and in religious guidance than with national loyalties.

185 Johnson, Founding the Far West, 50-51; Loewenberg, 166.

${ }^{186}$ Marshal, 124.

${ }^{187}$ Fred Lockley, "Ewing Young," Oregonian, March 10, 1940; Holmes, 128.
} 
20. Philip Leget Edwards, a schoolteacher and the WCC treasurer, summed up the difficulties of the trail when he wrote in his diary, July $20,1837:^{188}$

And then the state of camp! Shut the book! The last month, what has it been? Little sleep, much fatigue! Hardly time to eat, many times! Cattle breaking like so many evil spirits and scattering to the four winds! Men, ill-natured and quarreling, growling and cursing! Have, however, recovered the greater part of the lost cattle and purchased others. Another month like the last, God avert! Who can describe it?

Without explanation, Edward's diary ends on September 18. Perhaps the unwarranted killing of an Indian by the Young party on September 14, followed by four days of revenge attacks took away his desire to write. Two apparently friendly Indians had entered the drovers' camp, one an adult and the other a tenyear-old boy. Three of Young's men had been on a fur trapping expedition that had been attacked by Indians some years before with much loss of life, and two of these men (George Gay and William Bailey) used the incident as an excuse to kill the older Indian—the boy managed to escape. ${ }^{189}$ Over the course of the next four days, revenge attacks by Indians wounded George Gay, and killed a few horses and cattle. In early October, after four grueling months on the trail, the cattle drive reached its destination in the Willamette Valley. ${ }^{190}$

Edwards, in a narrative written five years later, noted that there were seventeen men in the WCC return trip and that they began with 800 head of

\footnotetext{
${ }^{188}$ Philip Leget Edwards, Diary of Col. Philip Leget Edwards Containing an Account of a Trip to the Pacific Coast (Sacramento: A. J. Johnson and Company, 1890), 27-28.

${ }^{189}$ Edwards, 42-47. Indians wounded George Gay with an arrow in his back; Edwards notes that Gay was first to shoot the Indian at the campsite on September 14.

${ }^{190}$ Holmes, 134.
} 
cattle and arrived in the Willamette Valley with $630 .{ }^{191}$ Regarding the disbursal of the animals at Young's corral in the Chehalem Valley, Young received 135, the Methodist mission 80, and Slacum 23. ${ }^{192}$ Disbursal information for the rest of the herd is not known exactly. However, if McLoughlin and his men took "half the stock" then they received 315 head. ${ }^{193}$ In a memorandum dated March 24, 1838, Ewing Young lists the number of cattle then belonging to him and some others: Young 92; Slacum 23; Edwards 49; Daniel Lee and Cyrus Shepard 20. The rest of the document lists trades and sales of over thirty cattle to more than a dozen settlers, with the last entry dated September $29,1840 .{ }^{194}$

Although there is no record of the route Young traveled in both of his overland trips to Oregon from California, he almost certainly took the old Oregon-California Road that had been in use for several years. Following indigenous trails, HBC fur trappers were the first white men to forge the trail south into California from the Rogue River region in the late 1820 s. ${ }^{195}$ In 1827, HBC trapper Joseph Gervais established the trail north from the Rogue River Valley to Fort Vancouver. The names attached to this road generally reflected the men or agencies responsible for its construction or improvement. Over the years, the trail was variously called the Hudson Bay Company's pack trail, the Old California Trail, California-Oregon Road, the Applegate Trail west of the Cascades, Siskiyou Trail, and several other

\footnotetext{
191 Philip Leget Edwards, Sketch of the Oregon Territory; or, Emigrant's Guide (Liberty, Missouri, 1842), 17. Young and his nine men bought 700 head of cattle for the WCC, and the other one hundred head belonged to the seven men who joined the trail in California.

${ }_{192}$ Holmes 134-136.

${ }^{193}$ McLoughlin, "Copy of a Document," 51.

${ }^{194}$ F. G. Young, "Ewing Young and his Estate," Oregon Historical Quarterly 21 (September 1920): 244-245.

${ }^{195}$ Oscar Osburn Winther, "The Development of Transportation in Oregon, 1843-49," Oregon Historical Quarterly 40 (September 1939): 321.
} 
names as well. ${ }^{196}$ In 1829, HBC brigade leader Alexander McLeod and his men opened the trail all the way from Fort Vancouver to the Sacramento River. They last called it the Siskiyou trail, and it approximately follows the path of what is now Interstate 5 (I-5). Much of this early trail work by Europeans followed Native American trails. ${ }^{197}$

After a lengthy illness, Ewing Young died in early February 1841 at an estimated age of forty-seven years. ${ }^{198}$ Still regarded as the wealthiest man in the Oregon Country, he died intestate and without heirs. The probate records for Young's estate indicate nearly one hundred head of cattle were sold or traded after his death. ${ }^{199}$ Records for Young's ledger book show that after his cattle drive and before his death, between October 1838 and February 1841, there were over forty sales and trades from his cattle herd. ${ }^{200}$ There were also others who owned substantial numbers of cattle in 1838: Philip Edwards (forty-nine cattle), and Daniel Lee and Cyrus Shepard (twenty cattle). ${ }^{201}$ On June 8, 1841, U. S. Navy Lt. Charles Wilkes, then on a mission to inspect the Oregon Country, recorded that he met a Mr. O'Neill in the Valley who owned 200 cattle. ${ }^{202}$

There is no doubt that the HBC held a monopoly on the cattle market at the time Young and his men left for California aboard the Loriot. The WCC drive broke that monopoly, and provided the first opportunity for every settler to own

\footnotetext{
196 James Kenneth Munford and Charlotte L. Wirfs, "The Ewing Young Trail," http://www.bentoncountymuseum.org/research/EwingYoungTrail.cfm; Mackie, 66.

${ }^{197}$ Munford, "Ewing Young Trail"; this major road is discussed in Mackie, 66.

${ }^{198}$ Holmes, 4, 146.

${ }^{199}$ F. G. Young, "Ewing Young and his Estate," Oregon Historical Quarterly 21 (Sept. 1920): 252279, passim.

${ }^{200}$ F. G. Young, "Ewing Young and his Estate," 227-252, passim.

201 F. G. Young, "Ewing Young and his Estate," 244-245.

202 Wilkes, Narrative of the United States Exploring Expedition during the years 1838, 1838, 1840, 1841, 1842, 4: 356.
} 
cattle. However, that opportunity did not translate into a wide disbursal of livestock because even after Young's probate auction most of the cattle were still held by a relatively few individuals who could afford them. That disparity provided the impetus for another California-bound cattle venture.

\section{Joseph Gale Venture}

In the course of searching for means to obtain cattle, a group of settlers decided to build a ship and sail to California where they would sell it and use the proceeds to buy livestock. By the fall of 1840 , six of the settlers had signed onto the project: John Canan, Ralph Kilbourn, Pleasant Armstrong, Henry Woods, George Davis and Jacob Green. ${ }^{203}$ Felix Hathaway, an experienced ship carpenter, offered his services for pay. However, Woods, Davis, and Hathaway quit sometime after the project was well under way.

The principal figure in this maritime cattle venture was Joseph Gale, a settler who had been recruited in the formative stages of the shipbuilding project, but who agreed to join only when he saw there was sufficient progress to ensure completion. He signed on shortly after the schooner was launched for a trial run on May $19,1841{ }^{204}$ Gale came to Oregon with Young in 1834 , and then served a few years as a trapper for the HBC before leaving to settle in the Tuality [Tualatin] Valley, now part of Washington County near Forest Grove. The settlers chose Gale to participate because he had prior experience as a seaman and as a navigator. ${ }^{205}$ Gale was unhappy with the condition of livestock in Oregon, and

\footnotetext{
203 Joseph Gale, "The Schooner Star, an Account of her Construction and Voyage to California," in TOPA (1891): 181.

${ }^{204}$ Oregonian, December 13, 1891.

205 Joseph Gale, "The Schooner Star," 183; Oregonian, December 13, 1891.
} 
accused the owners of the Willamette Valley's three largest herds-Methodists, HBC, and Ewing Young — of holding their animals "with such tenacity that it was next to an impossibility to purchase them at any price."206

Fortunately for Gale and his men, Lt. Charles Wilkes arrived on the Columbia (April 1841) at the same time they were having difficulties obtaining needed equipment from McLoughlin. The Chief Factor speculated that the schooner crew actually wanted to become pirates and, in any case, they were inexperienced sailors and were “... making a coffin for themselves ...."207 Wilkes advised Gale and his men to handle the discord with diplomacy; Wilkes later said that his advice had apparently worked because McLoughlin opened his stores to the crew. $^{208}$

The boat completed, the crew made a successful five-day run along the coast, reaching the Port of San Francisco on September 17, 1841. During that fall, Gale succeeded in trading the schooner for 350 head of cattle, and the crew agreed to rendezvous in the spring at [Cache] "Cash" Creek. ${ }^{209}$ This meeting place was about one hundred miles east of San Francisco in present day Yolo County. It was an old Hudson Bay Camp, so-called "Cache" because it was where HBC trappers used to store their furs. ${ }^{210}$

Gale worked to attract more men and stock for the return journey by posting

\footnotetext{
206 Dean Collins, Star of Oregon (Portland, Oregon: Binfords and Mort, 1943), 45.

207 Joseph Gale, "The Schooner Star,", TOPA (1891): 183.

${ }^{208}$ Wilkes, Narrative of the United States Exploring Expedition during the years 1838, 1838, 1840, $1841,1842,4: 342$. Wilkes arrived in Oregon in April of 1841. Although he does not mention having intervened to influence McLoughlin's sudden turnabout, Wilkes likely exercised his own diplomatic skills.

${ }^{209}$ Joseph Gale, "The Schooner Star," TOPA (1891), 190.

${ }^{210}$ Mildred Brooke Hoover, et al., Historic Spots in California, revised by Douglas E. Kyle (Stanford: Stanford University Press, 1990), 533.
} 
"circulars" about the amenities Oregon had to offer. His recruiting efforts were rewarded, and when the party left Cache Creek in the spring of 1843 it included over forty men, twelve hundred cattle, six hundred horses, and nearly three thousand sheep. ${ }^{211}$ Seventy-five days later the men and livestock arrived in the Willamette Valley without having sustained a major incident and with few animals lost. ${ }^{212}$ No one recorded the journey to Oregon, and little is known of the men who joined the rendezvous at Cache Creek and finished the drive.

Gale wrote an eleven-page history of his cattle buying expedition thirty-eight years after it happened, and it remains the venture's only primary source. His claim that his outfit broke an HBC cattle monopoly, however, is not entirely supported by the evidence. In 1842, Elijah White helped bring what is considered the first organized wagon train to Oregon. White's entourage included approximately one hundred immigrants, eighteen wagons and a herd of cattlealthough the number of cattle is nowhere enumerated. ${ }^{213}$ And the 1843 immigration brought, within sixty days of Gale's return, nearly 1,000 cattle. ${ }^{214}$ It was a convergence of livestock that fellow pioneer John Minto said "more than

\footnotetext{
${ }^{211}$ For numbers of livestock, see Joseph Gale, TOPA (1891): 191. Note also, p.191, wherein Gale gives his date of departure from Cash Creek as May 14, 1843. Either this date is suspect, or Gale was mistakenly or intentionally recorded as present at the historic vote in favor of the organization of the Oregon Provisional Government at Champoeg on May 2, 1843: see Oregon Historical Quarterly 13: 114, and J. Henry Brown, Political History of Oregon (Portland, Oregon: Lewis and Dryden, 1892), 99. Gale had to have been present at the July 5, 1843 Oregon Provisional Government meeting in which he was sworn in as a member of the executive committee. For this election, he was often referred to as one of Oregon's first Governors: See also Bancroft, History of Oregon 1: 306, 312; see also the Oregonian, March 21, 1983.

${ }^{212}$ Gale, TOPA (1891): 191.

${ }^{213}$ Marshal, 371.

${ }^{214}$ Marshal, 371.
} 
doubled the value of neat cattle" in the Willamette Valley. ${ }^{215}$

Regarding the price of cattle, the evidence also does not support Gale's statement that "it was next to an impossibility to purchase them at any price". ${ }^{216}$ Young's probate records and other ledger entries reveal that between 1839 and 1841 Gale bought eight head of cattle for roughly fifteen dollars each. ${ }^{217}$ That price compares in a fair way to the cost of WCC cattle in 1838 at $\$ 7.67$ a head before a four-month drive from California.

The importance of cattle to the settlers in the period before 1848 should be placed into context because to own a large herd in this period was to be wealthy. Just how bereft of real money the settlement was is perhaps best represented by one pioneer who remembered having received only twenty-five cents in cash between 1844 and $1848 .{ }^{218}$ S. M. Gilmore, an immigrant who arrived in 1843, noted that money was so scarce that agricultural produce and labor were worth more to the HBC and the American merchants than cash: "... business is done here altogether by exchanging commodities." ${ }^{219}$ Pioneer Medorum Crawford recalled that upon his arrival in 1842 he discovered that a man's livestock announced his financial condition and with cattle he could buy anything for sale. 220

215 "John Minto, "Development of the Cattle Industry," undated narrative, Oregon Historical Society, MSS 752, Box 2. See also John Bach McMaster, A History of the People of the United States (New York: D. Appleton and Company, 1920), 7 (1841-1850): 299; McMaster's source is the Nile Register, July 29, 1843 in which a census of the Oregon immigrants taken at the Big Blue River in Kansas counted 973 loose cattle, and 698 oxen.

${ }^{216}$ Collins, 45.

${ }^{217}$ F.G. Young, "Ewing Young and His Estate," 232, 279, 244-245.

218 James Henry Gilbert, Trade and Currency in Early Oregon (New York: Columbia University Press, 1907), 44, 45.

${ }^{219}$ S. M. Gilmore, "Letter from Oregon," Oregon Historical Quarterly 4 (September 1903): 283.

${ }^{220}$ Harry L. Wells, A Popular History of Oregon (Portland, OR: David Steel, Printer, 1889), 250. 
Before the fall of 1843 , a limited number of cattle in the Willamette Valley inhibited prosperity, but the combined herds introduced by Joseph Gale and thousands of new immigrants resolved the problem. Yet despite their importance to farmers in the Willamette Valley, an outside cattle market would not develop for western Oregon until 1858 when a strong demand for fresh meat accompanied the discovery of gold in British Columbia's Fraser River Valley and other mines further inland. ${ }^{221}$

\section{The Oregon Producers' Exporting and Importing Company (OPEIC)}

Wheat was so important to early settlers that in December 1845, the Provisional Government made it a legal tender in all ways equal to gold and silver. $^{222}$ And in 1847, a perception that outside agencies were suppressing wheat prices led to the American settlement's third working-farmer cooperativethe OPEIC.

At the time, it was not difficult to convince the isolated and money-strapped subsistence farmers in the Willamette Valley that greedy profiteers were manipulating the market. An absence of knowledge regarding the enumerated issues of supply and demand bred suspicion among farmers that a market for their surplus was being unjustly denied them, and their observations regarding the few and infrequent appearances of American trading ships fed into these conspiratorial notions. They were also unhappy with the usual marketing procedure wherein their agricultural commodities-primarily wheat and cattle-

221 J. Orin Oliphant, "The Cattle Trade on Puget Sound, 1858-1890," Agricultural History 7 (July 1933): 129-130.

222 Gilbert, 47-48. 
were exchanged with merchants who honored only their own receipts. This practice was sometimes to the detriment of the receipt holder because the shopkeeper might be out of a needed item or would charge more than other merchants for the same product. Settlers complained that the Willamette Valley's three American stores were chronically short of needed merchandise, charged exorbitant prices, and offered products that were sometimes of poor quality; ${ }^{223}$ they also criticized the HBC for striking the bushel measures in order to settle the wheat and thereby gain a few extra pounds in the exchange. ${ }^{224}$

By early 1847, the list of grievances and suspicions galvanized a group of Tualatin Valley settlers who called a meeting for the purpose of cooperative relief. It had been three years since Joseph Gale's cattle drive, during which time the American immigrant population had grown from slightly more than 1,000 to more than $6,000 .^{225}$

Although farmers considered American merchants complicit, most of the blame for economic complaints inevitably fell to the $\mathrm{HBC}$ because of its dominant position in the region. By the time American immigrants began to arrive in 1834 , the HBC had developed a successful commercial infrastructure that placed any competition at a disadvantage: Duty-free imports allowed the English to undersell American merchants; the HBC maintained a well-established trading circuit; and

\footnotetext{
${ }^{223}$ Throckmorton, 55; the American store owners were Pettygrove, Couch, and Abernethy. Howison, 22 (Howison calls the three American mercantile houses "enormously high").

${ }^{224}$ Bancroft, History of Oregon 1: 209.

225 John D. Unruh, Jr. The Plains Across: The Overland Emigrants and the Trans-Mississippi West, 1840-60 (Chicago: University of Illinois Press, 1979), 119.
} 
the lack of a "fixed currency" forced the Willamette Valley farmers to barter with bags of wheat, script, and sometimes even rocks. ${ }^{226}$

In 1846, Lt. Neil M. Howison of the United States Navy, then on a mission to reconnoiter the Oregon Country, noted that a lack of demand for the settlers' wheat surplus had caused it to pile up in the granaries. ${ }^{227}$ In 1846 , farmers in the Willamette Valley produced an estimated 150,000 bushels of wheat, of which 50,000 was surplus and available for export. ${ }^{228}$ American merchants bought settlers' wheat and sold it on established trade routes, especially at Sandwich (Hawaiian) Island ports. The HBC bought surplus wheat from the Americans in order to fulfill a supply contract with the Russian-American Company at Sitka, as well as to supply the Hawaiian Islands, but the sum-total of the two trading enterprises was not enough to deplete the settlers' surpluses. ${ }^{229}$

A proposal that Oregon farmers organize what came to be called "The Oregon Producers' Exporting and Importing Company," is first mentioned in the January 7, 1847 edition of the weekly Oregon Spectator. In a letter to the editor signed "M" (General Morton M. McCarver), the idea of a "grand and combined exporting company" organized by farmers was proposed as a solution to suppressed prices and a lack of vessels willing to transport their surplus

\footnotetext{
${ }^{226}$ Howison, Oregon, A Report, 22. Howison points to lack of fixed currency, isolation, and perilous river navigation as the culprits in suppressing economic development in the American settlement; See also Throckmorton, 58-69.

${ }_{227}^{22}$ Howison, Oregon, A Report, 23.

${ }^{228}$ Oregon Spectator, January 7, 1847; Bancroft, History of Oregon, 2: 2-see note 2.

${ }^{229}$ Lansford Warren Hastings, The Emigrant's Guide to Oregon and California (Princeton: Princeton University Press, 1932), 63; Gibson, 94-95, and on p.142-see note 23.
} 
commodities. ${ }^{230}$ In the same issue, another letter signed by "Rocky Mountain Boy" announces a meeting to take place in Tualatin for the purpose of organizing in opposition to "... merchants and shippers, who have united to tie us down and prevent us from getting the just reward of our labor ...." Months earlier, in the July 9, 1846 Spectator, General McCarver lamented that no "vessel of trade" has entered the Willamette River since the prior fall. In his letter, McCarver lamented about inadequate shipping, price-fixing, geographical isolation, and an indifference by the United States that rendered an "industrious farming community prey to the insatiable appetite of avarice and monopoly."

A more balanced response to the conspiratorial rhetoric appeared in the April 1, 1847 Spectator in which the writer advised the farm community to consider the plight of the merchant. The author, who signed his name "Honestas," argued that the merchant not only takes a great risk due to the difficulties in buying insurance, but also has no certainty of either a market or prices in the current trading environment. He concluded with a homily on how easily farmers accumulated wealth in the Willamette Valley in comparison to lands east of the Rocky Mountains, and how much more gratifying it was to be self-reliant than it was to form alliances with purveyors of "repudiation and mobocracy." Honestas was almost certainly replying to McCarver's numerous overwrought letters.

Another point Honestas could have made was that American trading ships looking to sell a cargo of supplies for cash were less apt to enter the Oregon

${ }^{230}$ Oregon Spectator, January 7, 1847. It is near certain that "M" is General Morton Matthew McCarver. Several other letters in the Spectator signed as "M," "MMM," or "Mudsill," are likely also his; all of the letters are written in the same style and share a well-versed understanding of market conditions. In addition, the Spectator indices at the OHS library recognize him under these same pseudonyms. 
market because the settlers only had commodities to trade. ${ }^{231}$ The accusation that the HBC structured and maintained a shipping monopoly in Oregon in the mid-1840s is also tempered by knowledge that American shipping merchants were plentiful along the Pacific Coast, and, in fact, Americans then dominated trade in the Sandwich Islands-the regions' principal agricultural market before $1848 .^{232}$

Other causes for the infrequency of ships include concerns about crossing the dangerous Columbia River bar. Two U. S. Navy officers had lost ships near the mouth of the Columbia (Charles Wilkes in 1841, and Lt. Howison in 1846). In addition, the immigrations of 1844 and 1845 brought nearly 4,000 people to Oregon, and their combined wheat raising efforts likely contributed to wheat surpluses. Crop records in this period are scarce, but one report written in 1844 stated that the wheat produced was enough for domestic use and a large quantity for exportation. ${ }^{233}$

During his stay in Oregon, Lt. Howison prepared his thoughts in regard to the settlers' surplus wheat predicament. He argued that Americans were held hostage to economic and political forces beyond their immediate control, but he also considered the Hudson's Bay Company to be a "stabilizing influence." ${ }^{234} \mathrm{He}$ blamed the limited access to an outside market on a lack of a fixed currency, distance, and the hazards of crossing the Columbia River bar. The navigation

\footnotetext{
${ }^{231}$ Avery Sylvester, "Voyages of the Pallas and Chenamus, 1843-1845," Oregon Historical Quarterly 34 (September 1933): 268.

${ }^{232}$ Ralph S. Kuykendall, The Hawaiian Kingdom, 1778-1854, Foundation and Transformation (Honolulu: University of Hawaii, 1938) 302.

${ }^{233}$ Peter H. Burnett, "Letter from Peter H. Burnett," Oregon Historical Quarterly 24 (March 1923): 105.

${ }^{234}$ Howison, 21.
} 
difficulties, he wrote, would be solved once there was sufficient trade to afford "pilots, light-houses, beacons, and buoys."235

The few letters and meeting reports regarding the OPEIC are chronicled in the Spectator and they comprise the extent of the company's historical record. Efforts to turn the company into a viable operation came to an end by the spring of 1847 . The exact cause of the OPEIC's demise will likely never become known because no record of the membership's final discussions has surfaced. The Oregon Spectator had been reporting all of the meetings up to last one on April 3, 1847, when the reports stopped. Apparently, the members dissolved the company shortly after this last meeting, and did so at an unreported gathering because the paper never mentioned it again (The Spectator was the only newspaper in the Territory at that time).

Records of the last meeting do not indicate that the company had insurmountable problems. The overall report indicated a growing level of enthusiasm: Plans had been made by Provisional Governor George Abernethy to accept "500 good barrels" of wheat for export at his "flouring establishment" by Sept. $20 ;{ }^{236}$ thirteen resolutions and "thirteen principals [to] be embraced in the constitution" were adopted; the next company meeting was scheduled for May 15

\footnotetext{
${ }^{235}$ Howison, 22.

${ }^{236}$ Five bushels of wheat went into making one barrel of flour; Oregon Spectator, April 18, 1850. See also John Macgregor, The Progress of America: From the Discovery by Columbus to the year 1846, vol. 2 (London: Whitaker and Company, 1847), 966; records for 1841-1845 confirm a common standard of five bushels of wheat per barrel of flour. Also listed are milling charges for the same period in Cincinnati that average less than the price of a bushel of wheat per barrel of flour. See also Jay M. Whitman, Water Rights Determination from an Engineering Standpoint (New York: John Wiley and Sons, 1918), 1-3 describes how the number of bushels per barrel can vary somewhat depending on the variety of wheat and grinding method. Whitman also mentions sources for the flour milling industry in the late 1700 s to mid 1800 s.
} 
at which time the members who had agreed to deliver wheat to Governor Abernethy were scheduled to commit to a specific amount. ${ }^{237}$

The likely impetus for the company's immediate dissolution came from an article in the May 13, 1847 Spectator that reported, for the month of April, three American vessels exported 836 barrels of flour, 171,000 bf of lumber, and 96,000 shingles from the settlement. The appearance of three American ships in one month was unusual and must have seemed a harbinger of better days for the commercially distressed farmers in that spring of 1847 . The news in May was followed by a letter in the June 10, 1847 Spectator, stating that California needed 20,000 barrels of flour before the end of the year. ${ }^{238}$

By the end of that summer, American ships had crossed the Columbia Bar at least eight times-and most of them to trade with the pioneers. ${ }^{239}$ To place this into context, between 1834 and 1847 fifty-four American ships entered and left the Columbia River, and between 1840 and 1846 only seven of these were traders. In comparison, there were at least six American trading ships in 1847-a figure that establishes it as the highest export year of the prior ten years. ${ }^{240}$

Historians have assigned multiple causes for the failure of the OPEIC to materialize. But a consistent argument among Historians Hubert Howe Bancroft, Arthur L. Throckmorton, and James Henry Gilbert is that California's demand for wheat and the large immigration of 1847 resolved the farm community's

\footnotetext{
${ }^{237}$ Oregon Spectator, April 29, 1847.

${ }^{238}$ C.E. Pickett, immigrant to Oregon in 1843, sent the letter from California.

239 Bancroft, History of Oregon 2: 15-18.

${ }^{240}$ Bancroft, History of Oregon, 2: 17-18; Throckmorton, 63.
} 
immediate economic problems. ${ }^{241}$ In fact, despite the noted wheat surplus, Oregon farmers were not prepared that fall of 1847 to adequately meet California's need for wheat and flour because the arrival of 4,000 Oregon immigrants in 1847 insured that the bulk of their production would be for domestic consumption. By 1850, Oregon's population had risen to 11,873 -a number that included an urban population of $2,789 .{ }^{242}$ Consequently, farmers had little difficulty during this period in finding a local market for their agricultural products.

Like its predecessors, the WCC and Joseph Gale's cattle venture, the OPEIC was a business arrangement organized around contractual obligations. Organized by working farmers, the organizations were farm cooperatives because they fit that model of cooperative first established in America by Connecticut dairy farmers in the early $1800 \mathrm{~s}^{243} \mathrm{~A}$ simple concept based on collective action in pursuit of economic gain, definitive features of the Connecticut cooperative included a membership of mutual occupational identities (in Oregon's case, farmer), and member ownership.

The next publicly reported farm cooperative appeared over the winter of 18591860. Organized by farmers in the upper Willamette region "for the purpose of buying or building boats," The Farmers and Shippers Transportation Company was a cost cutting response to high rates for freight then charged by steamboat

\footnotetext{
241 Throckmorton, 60-61; Gilbert, 68-71; Bancroft, History of Oregon 2: 21-22.

${ }^{242}$ Bowen, 56.

${ }^{243}$ Bob Cropp and Truman Graf, "The History and Role of Dairy Cooperatives," http://www.uwcc.wisc.edu/info/dairy/history.pdf (January 2001).
} 
owners. ${ }^{244}$ A committee drafted a constitution and appointed a canvassing agent to solicit a minimum operating startup of fifteen thousand dollars from prospective members. ${ }^{245}$ Apparently, the cooperative failed to secure the needed startup costs because it, like the OPEIC, disappeared without further notice.

${ }^{244}$ Oregon Farmer, "Steamboat Convention," January, 1860. The article lists eighteen locations where the canvasser, A. C. R. Shaw, planned to meet the valley's farmers . At least fifteen of these locations were river shipping points.

${ }^{245}$ Oregon Farmer, "Steamboat Convention" January, 1860. 


\section{Chapter Three}

\section{8: Gold, Growth, Towns and Transportation}

All that Oregon has wanted was a good market, the facilities for carrying her produce to that market, and the protecting care of the home government; the home government, we trust, is about to extend her fostering care, the mines have already brought the desired market, the mines will bring facilities for carrying provisions to the mines, and the mines will materially contribute to make Oregon know and develop her great resources.

-Oregon Spectator, October 12, 1848

\section{Gold}

A ship captain, plying his schooner from San Francisco to Portland, first brought the news of the California gold strike to Oregon in August $1848 .{ }^{246}$ By October 1848 an estimated three thousand Oregonians had left for the California mines, and by January 1849 they had brought home an estimated $\$ 400,000$ in gold dust. ${ }^{247}$ The Spectator noted that all occupations, rural and urban, were represented in the exodus - the paper even had to shut down for a few months because its printer left for the mines. ${ }^{248}$ An editorial in the July 25, 1850 Spectator argued that there was more profit to be made by growing crops for new immigrants as well as for future miners who were almost certain to discover gold in Oregon (the editor would prove to be prophetic).

The gold discovery created great excitement in the settlement community, but it also invited controversy from those who worried that Oregon was going to be

\footnotetext{
${ }^{246}$ Bancroft, History of Oregon, 2: 42-43.

${ }^{247}$ Oregon Spectator, Oct. 12, 1848. Bancroft, History of Oregon, 2: $42-43$ (see note 2); Oregon Spectator Oct. 12, 1848; See also Throckmorton, 88.

${ }^{248}$ Oregon Spectator, September 7, 1848.
} 
"ruined" because farmers were abandoning their farms. ${ }^{249}$ John Minto, a pioneer horticulturist and a recognized founder of Oregon's sheep industry, noticed a farming slowdown: "From 1848 to 1852, the industries of Oregon connected with the resources of the soil were suspended except as to horticulture ...." ${ }^{250}$ Minto said that the exodus of Oregon farmers during the gold rush of 1848 caused such an increase in the price of mutton that more and better sheep soon left south for California than the latter state had ever sent north. In 1852, pioneer George E. Cole recalled that wheat was scarce in Oregon because there were too few farmers at home, and field labor was difficult to find at any price. ${ }^{251}$

For productive farmers, however, the sudden rise of commercial opportunity held out promise for a better life. The hum of commerce and population growth in the small towns and wheat growing areas of the upper Willamette also motivated the merchant class to expand efforts into the area. By 1850, thirty-eight merchants had moved into Marion, Polk, and Yamhill Counties, and four had moved into Linn and Benton Counties. ${ }^{252}$ An Oregonian article advised farmers to keep an eye on the markets for opportunities to sell surplus goods. ${ }^{253}$

Economic conditions during the gold rush period were subject to rapid change, and so were the anecdotal observations that attempted to define them. Minto

\footnotetext{
${ }^{249}$ An editorial in the Spectator, October 12, 1848, warned that some citizens feared that the gold mania had already "ruined" Oregon because no one would want to plow and plant when ten dollars to one hundred dollars a day could be made at the mines. The editor advised that Oregon could raise one hundred million bushels of wheat, and lectured gold-hungry farmers to work their farms and await the demands of a growing population; "Is not a market for your wheat, beef, pork, potatoes, peas, beans, garden vegetables, fish, and lumber a desirable matter?"

${ }^{250}$ Minto, Oregon Historical Society, MSS.

${ }^{251}$ George E. Cole, Jottings of Personal Recollections of a Pioneer of 1850 (Washington D.C.: Library of Congress, 1905), 45.

252 Throckmorton, 121.

${ }^{253}$ Robbins, 98.
} 
later tempered his observations of a four-year period (1848-1852) of economic gloom in the agricultural industry by remarking that after the gold rush the cost of food everywhere was at "almost panic prices" and that the promise of better returns inspired some Oregon farmers to return to their farms. ${ }^{254}$ Minto's assessment that many farmers returned to their farms is corroborated by other pioneers' observations. James D. Miller, arriving at Oregon City in November 1848 , noted that by January 1849 , men were returning and that "all, without exception, had gold dust," some in the thousands of dollars. ${ }^{255}$ In a speech delivered in the summer of 1849 , Territorial Governor Joseph Lane remarked::256

I am happy to know that many of our people, who have been to the mines, are returning to their homes and farms, and it is to be hoped, are satisfied and determined to remain and renew their farming and other occupations. The gold excitement, occasioned the absence of a large part of our laboring population. Many of them had failed to put in crops; fine farms are laying idle, consequently the crops, this year, will fall short of an average one; but there is no doubt, that with the grain on hand, there will be sufficient supply for home consumption.

That many Oregon farmers would return to their land was not surprising. Dean May, in his study of three frontier communities, found that Oregon pioneers were more culturally bound to their land than were pioneers who chose to settle elsewhere. May concluded that for Oregon settlers, most of whom previously held Midwestern farms that averaged less than 150 acres, the chance to own 320 to 640 acres of free land represented a means of passing large estates to

\footnotetext{
${ }^{254}$ Minto, "Sheep Husbandry," 223.

255 James D. Miller, "'Early Oregon Scenes: A Pioneer Narrative," Oregon Historical Quarterly 31 (March 1930): 67.

${ }^{256}$ Oregon Spectator, "Governor's Message to the Fellow Citizens of the Counsel and the House of Representatives," July 17, 1849.
} 
their heirs. ${ }^{257}$ Such was the mindset of southern folk whose ancestral values had been shaped in a world of plantations and entail, and where large land holdings provided a touchstone of wealth, esteem, and heritage. ${ }^{258}$

Oregon farmers who stayed home and harvested their fields in 1849 sold their wheat for two dollars a bushel-an amount over three times the pre-gold rush prices in $1848 .{ }^{259}$ George Abernethy, merchant at Oregon City and former Provisional Governor, was one of the first to profit from the demand for flour in California. Abernethy had locked in a healthy supply of the 1848 wheat harvest price at $\$ .60$ to $\$ .625$ cents a bushel, which equates to $\$ 3.00$ to $\$ 3.25$ per barrel of flour plus milling costs. ${ }^{260} \mathrm{He}$ then realized a quick profit when flour rose to $\$ 10$ per barrel in December and to $\$ 12-15$ by February 1849. In San Francisco, flour was selling for $\$ 25$ per barrel and, for a time, at the mines for the exorbitant price of $\$ 100$ a barrel. ${ }^{261}$ However, by 1852 , wheat farmers in California began to increase production and prices for Oregon flour correspondingly dropped. ${ }^{262}$

Oregon was essentially an agricultural economy, thus, while the influx of gold boosted overall economic conditions in the 1850 s, farmers bore the brunt of the

\footnotetext{
${ }^{257}$ Dean L. May, 146-150. From the United States seventh (1850) census, the average farm size in Indiana was 136, and in Illinois the average was 158. In Oregon, 1850, the average farm size was 372 acres.

${ }^{258}$ Dean L. May, 146-150.

259 Throckmorton, 95.

${ }^{260}$ Because grain milling costs had been subject to mill operator whimsy, in 1851 the Territorial Legislature enacted laws standardizing what mills could charge: "That the owner or operator of any gristmill shall be entitled to one-eighth part of all wheat, rye or other grain ground and bolted; one-tenth part of all rye, malt, buckwheat or other grains, ground or chopped only; and oneseventh part of all Indian corn ground in said mill": see M. P. Deady, compiler, General Laws of Oregon, 1845-1864, chapter LV "Of Tolls for Grinding Grain," Sec. 1 (Portland, Oregon, 1866), 924-925.

261 Throckmorton, 94. The Oregon Spectator, December 28, 1848, has wheat selling in San Francisco for $\$ 25$ a barrel while it was for sale in Oregon at $\$ 10$ a barrel.

${ }^{262}$ Olsen, 116.
} 
decade's numerous wild market swings. Compounding the problems associated with persistent fluctuations in Commodity prices were two economic depressions, one in 1854 and another in $1860 .{ }^{263}$ Yet despite persistent cycles of economic malaise, 41,100 overland immigrants came to Oregon between 1850 and $1860^{264}$ During the life of the Oregon Donation Land Act (1850-1855), an estimated 27,700 overlanders settled in Oregon. ${ }^{265}$ The majority of farmers emigrated from the Midwest where they had become familiar with economic hardshipsparticularly those who were settled when the Panic of 1837 manifested its destructive course on Midwestern agriculture and land prices in the early $1840 s^{266}$

It has been difficult for historians to adequately assess the economic conditions of Oregon farmers in the post gold rush period because the rapid fluctuation of prices rendered transitory any beneficial or deleterious effects that such changes imposed. Supply and demand were disjoined and volatile throughout the 1850s, and were thus inadequate gauges for all but short-lived market conditions. One pioneer, writing in 1859 , stated that during his eight years

\footnotetext{
${ }^{263}$ See Throckmorton, $179-180$ for the depression of 1854, and page 225 for the depression of 1860. See also page 209 for a table listing the monthly prices of wheat from 1853 to 1861 . For examples, in the fall of 1854 the price of wheat fell to 50 percent less than prices in the spring, and prices in 1860 were the lowest of the prior nine years. A credible examination of the tumultuous economics of agricultural commerce during this period is beyond the scope of this paper. For a more thorough review, see Throckmorton, 85-106, and 159-180.

${ }^{264}$ Unruh, 120.

${ }^{265}$ Unruh, 120. Details of the Donation Land Act are prevalent in the historiography; it allowed 320 acres of free land for single men and 640 acres for a married couple.

${ }^{266}$ Dorothy Johansen, "A Working Hypothesis for the Study of Migrations" The Pacific Historical Review 361 (February 1967): 4; Johansen's study concluded that 66 percent of Oregon land claim applicants had married in four Midwest states; see also Jesse Douglas, "Origins of the Population of Oregon in 1850," Pacific Historical Review 41 (1950). The Panic of 1837, an east coast banking and real estate depression, is researched in Reginald Charles McGrane's, The panic of 1837; some financial problems of the Jacksonian era (New York: Russell and Russell inc., 1965), see pp.126-128 for a brief view of the depression's adverse effect on Midwestern agriculture.
} 
in Oregon he had witnessed wheat selling between $\$ .63$ and $\$ 5.50$ a bushel. ${ }^{267}$

Mixed messages aside, the economic outlook for all Oregon markets improved quickly after the gold rush in $1848 .{ }^{268}$ By the end of 1849 , the population in California was 100,000 , and with the bulk of California immigrants choosing gold mining over agricultural pursuits, the demand for farm products was strong. Prices rose for Oregon exports, per capita net worth increased, and Oregon's merchant class increased their importations of durable goods. Reminiscing, one old Oregon pioneer recalled that in 1849 money "was plentiful and goods of various kinds were brought in by ships from the East and indeed from all parts of the world."269 For Oregon farmers, the years from 1849 to 1852 represented a period of unprecedented commercial opportunity with prices for agricultural products rising between 200 and 300 percent. ${ }^{270}$

After the harvest of 1851 , there was not enough wheat for the domestic market in 1852. Ten thousand immigrants arrived in the fall of 1852 and put a severe strain on already limited stores of grain, causing flour to increase in price from between ten and forty-two dollars per barrel. Wheat exports to California were sharply down, and, by January 1853 , flour was so difficult to find that it had to be imported. However, local merchants tapped the Chilean market and imported flour in such quantities that, by the end of spring, flour had again been

\footnotetext{
${ }^{267}$ Robert Horace Down, A History of Silverton Country (Portland, Oregon: Berncliff Press, 1926), 233.

${ }^{268}$ Gordon B. Dodds, Oregon: A Bicentennial History (New York: W. W. Norton and Company, 1977), 72.

269 Gilbert, 78.

${ }^{270}$ Gilbert, 76 .
} 
reduced to reasonable prices. ${ }^{271}$

Oregon farmers' diligent response to a rising demand for staples in California between 1848 and 1852 helped to create a commodity surplus in California. A corresponding decline in prices created a short-term depression in Oregon. While Oregon's production of wheat, flour, and lumber products contributed to the market glut, merchants and entrepreneurs were also responsible for the oversupply. Prices in California had been so profitable that merchants swarmed the area with goods, and some miners quit mining and began merchandizing. Some people said that enough tobacco had been shipped and stored in San Francisco to last sixty-five years, and others wondered if the "law of supply and demand had been suspended."272

Among those who fell victim to the vagaries of a declining market was Benjamin Dore, a carpenter and trader in San Francisco who wrote in his journal in June, 1851: "The schooner Matthew Vassar arrived from Oregon, loaded with potatoes, butter, eggs, cider, etc., which I owned a share in, expecting it would sell well, but found the market full and does not sell very well." ${ }^{273}$ Dore's comment indicates there was also a market downturn for Oregon farmers. But when Dore visited French Prairie two months earlier, in April 1851, he found the farmers "well contented, live[ing] very easy, work[ing] but a small part of the time,

${ }^{271}$ Throckmorton, 165-166; George E. Cole, Jottings of Personal Recollections of a Pioneer of 1850 (Washington D.C.: Library of Congress, 1905), 45. For 1852 immigration numbers, see Unruh, 120.

272 John Walton Caughey, The California Gold Rush (Berkeley: University of California Press, 1948), 214-216.

${ }^{273}$ Dore, Benjamin. "The Journal of Benjamin Dore: One of the Argonauts." California Historical Society Quarterly 2 (July 1923): 135. 
and all getting rich., ${ }^{274}$ His assessments were more illustrative of the transient effects of a chaotic free market than a description of any lasting economic condition. To further illustrate the uncertainty of the wheat market, by 1860 California became a surplus wheat producer, milling 1.9 percent of the nation's flour with only 1.2 percent of the nation's population. ${ }^{275}$ California's surging increase in overall agricultural production meant that Oregon lost its principle export market, and Oregon sank into another short-lived depression by the spring of 1860 .

For Oregon farmers, downside market conditions were tempered by gold rushes in southern Oregon (1852), Colville, Washington (1855), Fraser River in British Columbia (1858), and Clearwater in Idaho (1860). In 1858, the Oregonian, as had the Spectator in 1850, urged farmers to stay home from gold mines and make more money in agriculture. ${ }^{276}$ There were many gold and silver discoveries in the Pacific Northwest in the 1850 s and 1860 s, but none produced the rapid individual wealth that came out of the 1848 discovery in California. For example, between 1858 and 1863, British Columbia exported ten million dollars in gold, while the peak year for California mines (1852) produced over eighty-one million dollars. ${ }^{277}$

Oregon's best yielding gold mines were discovered in 1852 in the Rogue

${ }^{274}$ Dore, Benjamin. "The Journal of Benjamin Dore," 131.

275 James N. Tattersall, "The Economic Development of the Pacific Northwest to 1920" (Ph.D. diss., University of Washington, 1960), 43-44.

276 Oregonian, April 24, 1858.

${ }^{277}$ For gold export from B. C., see Robert E. Fickin, "The Fraser River Humbug: Americans and Gold in the British Pacific Northwest," The Western Historical Society 33 (autumn 2002): 313. For annual gold production (1848-1876) in California see The California State Mining Bureau, vol. 30 (September 1903): 268. 
River area in and around Jacksonville. Pack trains and wagons from as far downriver as Oregon City carried farm goods to southern Oregon miners. ${ }^{278}$ These mines and their effect on agricultural development comprise much of the subject material in chapter 5 .

\section{Towns and Transportation}

By late 1850, Oregon had experienced gold rushes, Donation Land Act, population growth, increasing demand for farm products, and an ongoing effort to expand and improve transportation routes. A fast and efficient means of transporting the Willamette Valley's agricultural products to the marketplace was particularly high on the settlers' list of needed projects. Roads, ferries, and bridges garnered attention and continual efforts at improvement, but private entrepreneurs generally focused on improving travel over the Willamette River and other interior streams because the waterways were ready-made and provided the least expensive and most efficient means of traveling to and from the marketplace. Transport over water dominated the conveyance of agricultural goods until the introduction of railroads into the Willamette Valley in the late $1860 s^{279}$

The lower Willamette is that portion between the river's mouth at the Columbia River and the falls at Oregon City, and the upper Willamette lies between Oregon City and Eugene; eight of the Willamette's tributary rivers were navigable enough to provide landings, and together these waterways provided

\footnotetext{
${ }^{278}$ Throckmorton, 206-207.

${ }^{279}$ Throckmorton, 314.
} 
the principal transportation arteries for supplying the valley's farmers and for taking their goods to market. ${ }^{280}$

In 1850, the four principal ports on the lower Willamette were Oregon City and Linn City on opposite sides of the river at the falls, Milwaukie, and Portland. The latter two were, respectively, four miles and thirteen miles downriver from Oregon City. All of these port towns were used to load and transport Oregon's farm commodities. An 1847 bill of lading for cargo shipped to California from Portland by Portland merchant F. W. Pettygrove provides a partial inventory of marketable farm products grown by Willamette Valley farmers: “... beef, potatoes, butter, cheese, cranberries, turnips, cabbage, onions, wheat, and flour."281 Competition between the ports on the lower Willamette was strong until 1849 when work on Canyon Road made it passable from Portland into the rich farmland of the Tualatin plains and gave Portland a clear commercial advantage. Historian Joseph Gaston summed it up when he wrote that farmers will take their produce by "... the shortest practical haul between farm and ship." 282 In effect, Canyon Road made overland transport of farm products to the shipping point at Portland a viable option for farmers living deep into the Willamette Valley. ${ }^{283}$

In 1850, The Pacific Mail Steamship Company (PMSC) inaugurated regular service in Oregon, providing mail, freight, and passenger transportation from

${ }^{280}$ K. M. Macduffee, Oregon Historical Quarterly 44 (1943): 1; these tributary rivers were, the Clackamas, Tualatin, Pudding, Yamhill, Lickiamute, Santiam, Boonville, and Long Tom.

281 Johansen, 215.

282 Johansen, 324.

${ }^{283}$ Joseph Gaston, Portland, Oregon, its History and Builders (Portland, OR: S.J. Clarke Company, 1911), 366; Harvey Whitefield Scott, ed., History of Portland, Oregon: with Illustrations and Biography (Syracuse, New York: D. Mason and Company, 1890), 114. Scott wrote that Canyon Road was the most important tool in establishing Portland as the premier city on the lower Willamette: "...for it fixed the trade of the farmers, brought down loads of grain and other produce, and the droves of cattle and hogs." 
Astoria to California. It immediately became the dominant ocean going steam shipper in the territory, and, in 1851, the company extended service eighty miles inland on the Columbia River to the deep-water landing at St. Helens. Portland merchants did not have a steam ship at the time, and merchants at rival ports refused to pick up the agricultural products that lay piling up on the city's wharf. Since farmers would not take their products the distance to St. Helens, there ensued an impasse that temporarily disrupted the shipping enterprise in Portland. The impasse ended when the PMSC realized that if it did not take Portland's cargo then another company would. In May 1851, the company abandoned its wharf at St. Helens and moved to Portland. ${ }^{284}$

Variously constructed river craft provided the principal means of transporting farm produce in the Willamette Valley during the 1840s; keelboat, canoe, raft, scow, and bateaux were some of the more commonly used descriptives. Farmers used these types of craft on the Willamette River as far inland as Salem, with several other loading points along the way. Portages around the falls were located at Oregon City on the east side of the river, and across the river at Linn City. ${ }^{285}$ Ocean going ships that docked at ports on the Willamette River before 1850 were all sailing vessels. Portages, landings, and small river towns went hand in hand during this period. Predating them were merchants whose country stores, according to historian Arthur L. Throckmorton, “... in all probability were the nuclei from which the small towns emerged."286

\footnotetext{
${ }^{284}$ Gaston, 367; Throckmorton, 120.

285 Throckmorton, 118.

${ }^{286}$ Throckmorton, 121.
} 
The further into the upper valley the settlers went, the longer the trek to Oregon City for supplies. In October 1847, Thomas Cox, a Midwesterner with a history of establishing small stores, was the first to open a store in the upper valley. Located at Salem, the new business conducted trades of merchandise for agricultural products in the accepted manner befitting an economy that was nearly bereft of money. Among his first payments received that opening fall were wheat, and a promised payment for ten dollars worth of butter. Over the next several months he received lumber, butter, pork, skins, and oats for his merchandise. $^{287}$

The Yamhill River enters the Willamette twenty-nine miles above Oregon City. Its navigability for eleven miles upriver to the towns of Lafayette, Dayton, and McMinnville made it an important route to the lower Willamette markets for farmers in the region surrounding the rich agricultural land of the Yamhill Valley. North of the Yamhill lay the equally fertile lands of the Chehalem and Tualatin Valleys, the latter hosting the overland gateway to Portland (Canyon Road). Before Canyon Road became passable in the late 1840s, the most common overland access to the lower Willamette for Tualatin area farmers was via a steep and rough wagon road over the Tualatin Mountains to Baker's landing near Linnton. ${ }^{288}$ Wagon travel throughout the 1840 s and 1850 s was often problematic. Travel over Canyon Road, for example, averaged between ten and twelve miles

\footnotetext{
${ }^{287}$ Throckmorton, 64; Jesse Steiwer Douglas, "Syracuse and Santiam City," Oregon Historical Quarterly 32 (September 1931): 200.

${ }^{288}$ Corning, 166-169; "Notes and Comments: Old Canyon Road," Oregon Historical Quarterly 19 (March 1919): 169-170.
} 
per day with many stops to disengage from the mud. ${ }^{289}$

In the spring of 1850 , a sixty-five foot flat bottom boat, owned by steersman $\mathrm{J}$. D. Miller and powered by four Klickitat oarsmen, became the first commercial river craft to enter the mouth of the Yamhill. Miller and crew stopped for sacks of wheat at a landing built by Louis Labonte, ${ }^{290}$ and, after stopping at Dayton and Lafayette, returned to the portage at Canemah with 350 bushels of wheat. ${ }^{291}$ During the rest of 1850 to the spring of 1851 , Miller and one competitor in a refurbished $\mathrm{HBC}$ bateaux had the river wheat traffic to themselves. But the two men went out of business soon after the first steamboat on the upper river, the Hoosier, began operating in May $1851 .^{292}$ In September 1851, the steamer Canemah followed the Hoosier and began operating between the village of Canemah (now part of Oregon City) and Salem—often carrying between 1,000 and 1,500 bushels of wheat. ${ }^{293}$ During the next two years, eight more steamers were vying for the agricultural trade above Oregon City.

In 1850, the launching of the Columbia at Astoria established it as the first steamship built in the territory. Working the Columbia and Willamette Rivers between Astoria and Oregon City, the Columbia had the steamer business to itself for a brief time. However, by the fall of 1853 there were fourteen

\footnotetext{
${ }^{289}$ Corning, 180.

${ }^{290}$ Louis Labonté, it will be remembered, was among the first of the HBC retirees to settle on French Prairie.

${ }^{291}$ Corning, 180-181.

${ }^{292}$ Corning, 180-181.

${ }^{293}$ Corning, 117.
} 
steamboats on the Columbia and the Willamette. ${ }^{294}$ Many of these boats went into disuse during Oregon's depression in 1854, but they nonetheless provided an infrastructure for future growth. Steamship service above the falls began in 1851, but was initially limited to no further than Corvallis because the city's merchants wanted Corvallis to remain the head of navigation for the upper Willamette. After 1856, a few steamboats extended service to Eugene. But because the river above Corvallis was swift and often narrow with several channels and sloughs, low water conditions rendered it navigable for less than six months a year. ${ }^{295}$ Thus, Corvallis remained the head of river navigation for most steamboats.

In 1856, the steamer James Clinton became the first to travel as far as Eugene. ${ }^{296}$ Steamer service on the upper Willamette was regular in the 1850 s, but continued to be hampered in the upper reaches near Eugene by shallow water and by too many obstructions. Thus, Harrisburg and Lancaster (Woody's Landing), both twenty-one miles downriver from Eugene, and Peoria, thirty-three miles downriver from Eugene, became the principal landings in the southernmost portion of the valley. ${ }^{297}$ A typical upriver cargo would include farming supplies, and a standard cargo for return trips would consist of wheat and livestock.

\footnotetext{
${ }^{294}$ Howard McKinley Corning, Willamette Landings: Ghost Towns of the River (Portland, Oregon: Oregon Historical Society, 1947), 23-25; Janice Marschner, Oregon 1859: A Snapshot in Time (Portland, Oregon: Timberline Press, 2008), 67; Throckmorton, 118.

${ }^{295}$ Corning, 115. See also E. W. Wright, ed., Lewis and Dryden's Marine History of the Pacific Northwest (Portland, Oregon: Lewis and Dryden, 1895), 60.

${ }^{296}$ E. W. Wright, ed., Lewis and Dryden's Marine History of the Pacific Northwest (Portland, Oregon: Lewis and Dryden, 1895), 34.

${ }^{297}$ Corning, 155-164. The flood of 1861 wiped out Lancaster and changed the course of the river. Thereafter, local farmers began unloading their products across the river at Harrisburg.
} 
Steamboat transportation prevailed in the upper Willamette until railroads began to service the area in 1871.

During his brief time as a flatboat operator, Miller established a regular thirtyfive-mile run from Canemah to the Yamhill River where he made several stops. A round trip took three days. His cargo was usually wheat destined for the flour mills at Oregon City, and his carrying capacity was 350 bushels. ${ }^{298}$ After quitting the river, Miller noticed the success of the Luelling-Meek nursery at Milwaukie, and he began planting an orchard on his donation land claim in the Tualatin Valley. By 1854, he had ten acres in apples, peaches, pears, and plums, and he was selling apples for one dollar a box. Two years later, however, the prices for fruit had dropped significantly, and he was forced to let it fall from his trees. ${ }^{299}$

In 1858, Miller returned to the river trade with a purchase of one-third interest in the steamer Hoosier. The partnership intended to improve navigation on the Tualatin River in order to ease passage to Hillsboro and Forest Grove, but the venture failed from a combination of insufficient traffic, logjams, and other river obstructions. ${ }^{300}$ Miller bought out his partners, taking full possession of the Hoosier, and then bought the steamer James Clinton. With the Clinton, Miller began regular runs to Butteville, Champoeg, Dayton, Lafayette, and McMinnville, "... carrying grain, flour, fruit, and all kinds of farm products." ${ }^{\text {301 }}$ Miller conducted a successful business until a large storm and flood in the winter of 1861-1862 destroyed thousands of bushels of wheat waiting for shipment along the shores

\footnotetext{
298 James D. Miller, "'Early Oregon Scenes: A Pioneer Narrative," Oregon Historical Quarterly 31 (June 1930): 167.

299 James D. Miller, "'Early Oregon Scenes, 172.

300 James D. Miller, “"Early Oregon Scenes, 176-172.

301 James D. Miller, "'Early Oregon Scenes, 176.
} 
of the Willamette. The water rose so high that warehouses burst from the pressure of swollen wheat. ${ }^{302}$

The Willamette Valley contains roughly 16,000 miles of streams, and farmers needed to cross many of them in order to cut distances to the marketplace. John Arthur, immigrant in 1843, recalled that taking wheat overland to the few gristmills then in operation required carrying the sacked wheat and wagon across a series of creeks, and each such effort required swimming the team across to yoke up again on the other side. ${ }^{303}$ In many cases, conveyance across large streams required either ferries or bridges. Because bridges were more costly and difficult to build, hundreds of ferries were constructed during the mid to late 1800 s - most of them were privately owned and maintained. In 1849, the Territorial Legislature passed an Act regulating ferries; ${ }^{304}$ Included were regulations that underscored the profit incentive for the construction and operation of ferries. All ferries were to be licensed for a fee of not less than one hundred dollars, and it was within the power of county probate courts to set rates for passage of "all persons, wagons, carts, carriages, horses, cattle, sheep, hogs, and other property."305

Early construction methods were by necessity often crude, as demonstrated by the ferry on the Santiam River built by Milton Hale in the mid 1840s. Hale

\footnotetext{
302 James D. Miller, "'Early Oregon Scenes: A Pioneer Narrative," Oregon Historical Quarterly, 31 (September 1930: 180.

303 John Arthur. "A Brief Account of the Experiences of a Pioneer of 1843," TOPA (1887): 99.

${ }^{304}$ Statutes of a General Nature Passed by the Legislative Assembly of the Territory of Oregon, 2d sess., 1850-1851 (Oregon City, 1851), 153-156; Charles Floyd Query, Oregon Ferries: A History of the Ferries on Oregon's Major Waterways since 1826 (Santa Cruz, California, 2004), 114-118.

${ }^{305}$ Statutes of a General Nature ... Territory of Oregon, 2d sess., 1850-1851, 155.
} 
used an adz, an axe, an auger, and a pocketknife to whittle out two large firs. He connected these two canoe-like affairs far enough apart to accommodate wagons, and then charged a toll for his troubles. ${ }^{306}$ In the 1840 s and 1850 s there existed ferries over most of the Willamette River's tributaries, including the Tualatin, Yamhill, Luckiamute, Long Tom, Santiam, and McKenzie. These ferries were used to transport all manner of agricultural goods, including livestock.

In 1849, U.S. military purser Dan O'Neil, stationed at Oregon City. recalled an assignment to transport supplies from Fort Vancouver to his station. He described the conditions of navigation on the Columbia and Willamette as a "tedious ..., difficult, and dangerous undertaking. Roads were not open for heavy wagon traffic, [and] the only way for getting the goods through was by open boat and manpower." ${ }^{307}$ Government recognition of the necessity of good wagon roads is evident in one of the earliest meetings preliminary to the formation of the Provisional Government. On February 17, 1841, settlers held a meeting at the Methodist mission for the purpose of drafting a system of governance. Included in the initial draft was a provision to appoint three road commissioners. ${ }^{308}$

Traveling to the river landings with wagons filled with a season's harvest was

\footnotetext{
306 Jesse Steiwer Douglas, "Syracuse and Santiam City," Oregon Historical Quarterly 32 (September 1931): 201; Charles F. Query, A History of Oregon Ferries since 1826 (Santa Cruz, California, 2008), 29; William L. Lang, Confederacy of Ambition; William Winlock Miller and the Making of Washington Territory (Seattle: University of Washington, 1996), 13-notes the importance of Hale's ferry across the Santiam, still operating in 1850 as the only place to cross the river for travelers headed north and south on the California-Oregon Road.

${ }^{307}$ E. W. Wright, ed., Lewis and Dryden's Marine History of the Pacific Northwest (Portland, Oregon: Lewis and Dryden, 1895), 29.

${ }^{308}$ J. Henry Brown, Political History of Oregon (Portland, Oregon: Lewis and Dryden, 1892), 8283. See also Oscar Osburn Winther, "The Development of Transportation in Oregon, 1843-49," Oregon Historical Quarterly 40 (December 1939), 315-316. Legislative attention to roads was extensive. During the period between the provisional government in 1843 to statehood in 1859 , the legislatures deliberated on 245 bills and acts in regard to roads alone.
} 
difficult. Wagon roads were often wet and muddy during the spring and fall harvests. ${ }^{309}$ There were no wagons in 1842, recalled pioneer Medorum Crawford, and as a consequence the Willamette Valley's farm produce was hauled to the river in crude carts of all kinds. ${ }^{310}$ On June 26,1844 , the provisional government passed legislation that appointed men to build a road from Willamette Falls to the falls of the Yamhill River. And on December 12, 1846, the governor approved legislation that called for the Canyon Road to run from Portland to the Tualatin Valley and then continue south until it reached the mouth of Mary's River in Polk County. ${ }^{311}$ The history of road building in this period is complex. The provisional government passed laws requiring that roads be twelve feet wide with an additional ten-foot right-of-way on both sides, and that the roads be kept free of obstacles. ${ }^{312}$ In December 1847, the same legislative body passed a law that extended authority for road building and maintenance to county judges. Each male resident, twenty-one years and older, was required to work two days a year on public roads, and property taxes were levied for roads at the rate of ten cents per one hundred dollar valuation. ${ }^{313}$ Even so, settlers often worked together to build roads, ferries, and bridges with no governmental authority or record keeping

${ }^{309}$ Oscar Osburn Winther, The Old Oregon Country: A History of Frontier Trade, Transportation, and Travel (Stanford: Stanford University Press, 1950), 125-126; Winther notes that roads were never good during wet weather, and that it was not until statehood in 1859 that Oregon realized a "boom" in road building.

${ }^{310}$ H. O. Lang, ed., History of the Willamette Valley (Portland, Oregon: Mimes and Lang, 1885), 250.

311 "Annual Address of Hon. W. D. Fenton" TOPA (1898): 77-78.

312 "Laws of Oregon 1843-1849," Asahel Bush, compiler (Salem, Oregon, 1853), 88-93; this Act passed June 22, 1844.

313 "Laws of Oregon 1843-1849," 17-22. 
involved. ${ }^{314}$ Road improvements in this period, however well made, did not change a preference for transport over the interior streams of the Willamette Valley.

In 1846, Jesse Applegate directed a crew of men and established the southern immigrant wagon road. Applegate began near Dallas, Oregon, in Polk County, and then continued south to Ashland in the Umpqua Valley where he and his crew turned east to Thousand Springs, Idaho. Applegate's road became an alternate route to Oregon, and it helped open up southern Oregon to Immigrant traffic. By 1859, two north/south territorial roads had been widened to sixty feet. The one hundred mile long Eastside Territorial Road ran north and south from Oregon City to Coburg, and connected with a territorial road at Monroe where it continued south fifty-seven miles to Anlauf in the Umpqua Valley. ${ }^{315}$ The Applegate Road, mentioned earlier, became a well-used section of the California-Oregon Road connecting the Willamette Valley to California. The story of its construction is well known and need not be discussed in depth here. For ease of simplicity, the entire north-south section of the Applegate road in Oregon is here referred to as the California-Oregon Road, and it approximated what is today Interstate $5(\mathrm{I}-5)$. In the pre-railroad times of western Oregon, the importance of the California-Oregon Road as an artery of commerce was of secondary consequence until it passed south of the Willamette Valley where its connecting trails and wagon roads became as important to commerce as the

\footnotetext{
${ }^{314}$ As noted by Oscar Osburn Winther, "The Roads and Transportation of Territorial Oregon," Oregon Historical Quarterly 41 (March 1940), 42-43. Building a transportation infrastructure during the first five years of the 1850 s remained largely a private enterprise.

315 Janice Marschner, Oregon 1859: A Snapshot in Time (Portland, Oregon: Timberline Press, 2008), 41.
} 
connecting waterways of the Willamette River. As the road wound its way south over the river valleys of the Umpqua and the Rogue, the region's Euro-American settlers developed a system of intersecting land passages consistent with the customary frontier practice of social and commercial expansion. The development of these linking routes was in the main fueled by commercial necessity, as in the road connecting the inland shipping port at Scottsburg, with Roseburg on the California-Oregon Road.

Constructing, maintaining, and improving transportation routes were part of the everyday experience for farm families in the mid 1800s. Government agencies were not yet adequately funded or staffed for the huge projects that were necessary. In 1851, for example, a Portland luminary laid down the first plank on Canyon Road amidst much fanfare and anticipation of its completion. The road was never planked, and its passage remained rough in foul weather for the remainder of the century. 


\section{CHAPTER FOUR}

\section{Agricultural Conditions}

As previously mentioned, wheat was the most important crop in the Willamette Valley settlement. Oats, in second place, was primarily used for animal feed; rye and Barley were also planted, but to a much lesser extent. ${ }^{316}$ In his study of the Willamette Valley before 1850, Bowen found that most farms planted a variety of grains and vegetables, and kept livestock based on domestic need and preference, physical environment, and market demand. Bowen's research of the 1850 census revealed the emergence of agricultural districts that varied in their particular crop and livestock combinations. Farms closer to the urban areas of the lower river-the Tualatin, Yamhill, and Chehalem valleysgrew more vegetables because they had a better chance of arriving at the market before spoiling. Farms upriver from Oregon City grew fewer market gardens, and concentrated on grains and livestock. On French Prairie, wheat reigned supreme while cattle and hogs were secondary, and dairy products were used primarily for home consumption. ${ }^{317}$

The average acreage possessed by individual Oregon farm households in 1850 was 371.8 acres. Only a little over one-third of the total farmland was classified as improved. ${ }^{318}$ Between 1850 and 1880, the federal government

\footnotetext{
${ }^{316}$ Bowen, 91; See also Dean L. May, 162-163; "A typical Sublimity (Marion County) farmer put much of his land in wheat and oats, but also raised small quantities of barley, potatoes, and corn." ${ }^{317}$ Bowen, 94.

${ }^{318}$ E. Dana Durand, ed., "Statistics for Oregon," Thirteenth census of the United States, (Washington, 1910), 610.
} 
defined improved land as "cleared land used for grazing, grass or tillage."319 In 1862, an editorial in the Oregon Farmer regretted that "... nearly all the farmers in the state have more land than they can tend. ${ }^{, 320}$ By 1850 , there is nothing to suggest that the average acreage of cultivated land on each farm had substantially changed from William Slacum's 1837 estimate of forty acres. The 1860 census shows that 43.5 percent of all farmland was improved. The increase was almost certainly due to the introduction and wide spread use of more sophisticated machinery like the horse-drawn chain thresher and the winnowing fan that are both described in the following section regarding crops.

As mentioned in the introduction, there was a commonly held perception that Oregon farmers were indolent and produced little in the way of commodity surpluses. ${ }^{321}$ These assumptions are not supported by the statewide agriculture production enumerated in the 1850 and 1860 United States census reports. In regard to wheat production, the following are comparison examples for Oregon, Indiana, Illinois, and California for bushels of wheat per farmer produced in 1850: Oregon, 125b; Indiana, 38b; Illinois 67b; California, 12b. Atack and Bateman, in a statistical sample of 7,306 farms gathered from the 1860 census, found that wheat production for nine Midwestern states averaged 105 bushels per farm. ${ }^{322}$ According to the same 1860 census, 5,806 Oregon farms produced 826,776

${ }^{319}$ Don R. Leet, Population Pressure and Human Fertility Response: Ohio, 1810-1860 (Arno Press, 1978), 108-109.

${ }_{320}$ Oregon Farmer, September 1, 1862.

${ }^{321}$ In the Oregon Spectator, "Gold and Farming," November 7, 1850, the editor admonishes the typical Oregon farmer for working little. In the Portland Daily Advertiser, February 14, 1860, a letter claims that Oregon farmers think not of tomorrow, and are "inactive." See also note 10, Johnson, et al.

${ }^{322}$ Atack and Bateman, 113. 
bushels of wheat for an average of 142 bushels per farm. Given that the Midwest was the strongest wheat producing region in the United States (producing, for example, nearly three times as much wheat as that produced in the eastern states), ${ }^{323}$ the results appear to contradict anecdotal evidence that Oregon farmers were more lax in their work ethic than were farmers elsewhere. This area of study obviously needs more work, but these comparative results regarding the nation's strongest grain crop are clearly more beneficial to Oregon than has been demonstrated in the court of public opinion.

\section{Crops}

Literature regarding the varieties and cultivation of wheat is scarce and otherwise absent in the historiography for the early pioneer period. As a subject of local discussion, wheat seldom appeared in published accounts until after the start of the Oregon Farmer newspaper in 1858. One account of early crop conditions was written by Oregon settler William Geiger, M.D. In responding to a circular from the United States Patent Office in 1850, Geiger described three varieties of wheat then used in the Willamette Valley: white fall wheat (sometimes called winter wheat); red-bearded or Mediterranean wheat; and bald red wheat. ${ }^{324}$ Two main varieties of wheat planted by the HBC were called spring red and [winter] white. ${ }^{325}$ Included in Geiger's letter were the best months for planting each variety, local preferences, cultivation practices, and expected yields and

\footnotetext{
${ }^{323}$ Atack and Bateman, 114. See also Agriculture of the United States in 1860; Compiled from the Original Returns of the Eighth Census. Joseph C. G. Kennedy, comp. (Washington, D.C., 1864), xxxi.

${ }^{324}$ William Geiger, "A Letter from William Geiger," Report of the Commissioner of Patents: Agriculture, 1850 (Washington D.C.), 12-14. In the Oregonian, November 4, 1900, John Minto said the most commonly used variety was "Oregon white winter wheat."

${ }^{325}$ Gibson, 142.
} 
prices. Winter wheat was the most commonly planted variety, and its price in 1850 was between one dollar and two dollars a bushel. This was a favorable price, given that wheat sold for one dollar a bushel during the "high" times in December $1847 .{ }^{326}$ Geiger described his unsuccessful efforts to grow hybrid wheat, and observed that it would benefit Oregon if some "agricultural periodicals" were available. ${ }^{327}$

Jesse Applegate, describing his experiences in the 1840s, said that the usual manner of planting grains was to plow in the fall or early winter, sow by hand, and then cover the seed with a wooden tooth harrow, or by dragging some brush over the field. ${ }^{328}$ The first settlers cut their grain crops with sickles. In 1840, Jason Lee introduced the first mowing cradles, which were sickles with baskets to catch the grain. ${ }^{329}$ The usual method of separating grain from the sheaves was by threshing with a flail, or by driving cattle or horses over the sheaves. Some farmers would thresh their wheat in an enclosure with a wooden floor, while others might thresh their wheat outside on hard packed earth. In 1851, Jesse Applegate, then farming in the Umpqua Valley, described a commonly practiced method of threshing: $:^{330}$

At the time of harvest, the weather is usually dry and pleasant. Wheat and oats are cut with a cradle, and peas pulled by hand. There being no

\footnotetext{
326 Throckmorton, 63.

327 "A Letter from William Geiger," Report of the Commissioner of Patents: Agriculture, 1850 (Washington), 13.

${ }^{328}$ Minto, Oregonian, November 11, 1900.

${ }^{329}$ Andrew Chambers, "Reminiscences," Early History of Thurston County, Washington: Together with Biographies and reminiscences of Those Identified with Pioneer Days, ed. Mrs. George E. Blankenship (Olympia, Washington, 1914), 158; Leslie M. Scott, "Soil Repair in the Willamette Valley," Oregon Historical Quarterly 18 (March 1917): 66.

330 Jesse Applegate, "A letter from Jesse Applegate," Report of the Commissioner of Patents: Agriculture, 1851 (Washington), 472.
} 
barns, a clayey spot is made smooth and hard by being dampened and beaten with mauls, or tramped with animals. Around it a high, strong fence is made, and over it those fond of the shade throw a few bushes. On this "floor," the grain is laid regularly, the heads pointing obliquely upward. A wild, skittish band of horses are turned in and driven against the bristling heads of the grain, and, by their scampering, in a very short time the wheat is threshed from the straw, and much of the straw itself broken to pieces, much more time being required to separate and remove it from the grain than is occupied in threshing. Leaving the bottom undisturbed to the last, as it is sometimes dirty, the threshed grain is pushed to the centre, and another floor laid down; and so on until the crop is threshed.

The HBC introduced the region's first water powered gristmill in 1828, but labor saving machines on the farm were rare until the late 1840s. Among the first farm machines in Oregon were two "mule-powered" treadmill threshers constructed by "Wallace and Wilson" from Oregon City in 1848. These implements were copies of machines that had been invented in 1830 by New England blacksmiths John and Hiram Pitts. The threshers quickly became popular with Oregon's farm community, but the machines disappeared during the gold rush, and the farmers returned to their old methods. ${ }^{331}$ The next machine appeared in 1850 when Thomas Otchin had a Pitts brothers power thresher shipped by sea from New York to Oregon where he first put it to use in Hillsboro. ${ }^{332}$ Other variously constructed threshers and separators (winnowers) became common by the mid-1850s. George Himes, long-time curator at the Oregon Historical Society, said that one of the horse drawn threshers he worked on in 1857 would produce 500 bushels of wheat in the time it took to produce 50

${ }^{331}$ Bowen, 89; Bancroft, History of Oregon, 2: 2; Oregonian, December 3, 1911.
${ }_{332}$ Oregonian, December 3, 1911. 
or 75 bushels using the old methods. ${ }^{333}$ The first hand cranked fanning mills appeared in the late 1840s, and the seed drill appeared in the mid-1850s. ${ }^{334}$

Pioneers in the 1830 s and 1840 s usually obtained their seeds from the HBC. Immigrants also brought their own seeds, and some waited to settle in before sending requests back east for the varieties of seeds they wanted. Transporting seeds to Oregon by ship risked spoilage, as recalled by Jesse Applegate's daughter, Roselle Putnam: "We can buy any kind of vegetable seeds which do not come very well after doubling the Cape-but we have raised of almost everything one could think of-the seeds we bought were put up by the Quakers of New York-are the best quality. ${ }^{\prime 335}$ In 1844 , the Jesse Looney family was the first to settle in the Santiam Valley, located ten miles northeast of Albany. Mrs. Looney began the first apple orchard in the valley with seeds she carried in a jar from the family's starting point in Independence, Missouri. ${ }^{336}$

Vegetables and potatoes sold well when the market for them was concentrated and nearby. In 1850, twenty farmers produced 8,280 bushels of potatoes, and farmers on the Clatsop plains found that ships' crews provided a ready market for their vegetable crops. In 1847, A. R. Dimick brought "shaker blue" or "early" potato seeds from Michigan from which he developed the Dimick potato, a variety that earned him a local nickname, the "potato king." ${ }^{337}$ Beans

\footnotetext{
${ }^{333}$ Oregonian, April 21, 1963.

${ }^{334}$ See Washington, TOPA (1903): 211 for fanning mill; See Oregonian, April 21, 1963 for seed drill.

335 "Letters of Roselle Putnam," Oregon Historical Quarterly 29 (September 1928): 262.

${ }^{336}$ Jesse Steiwer Douglas, "Syracuse and Santiam City," Oregon Historical Quarterly 32 (September 1931): 199.

${ }^{337}$ William N. Wise, "The History of Potatoes in Oregon," in Dictionary of Oregon History (Portland, Oregon: Binfords and Mort, 1989), 202-203; Bancroft, History of Oregon 1:638.
} 
grew well but were not commonly grown, and peas were typically planted for replenishing the soil or for domestic use. ${ }^{338}$ When the weather was just right, corn grew well, but the Willamette Valley's cool climate and potential for storms made it a risky crop.

\section{$\underline{\text { Cattle }}$}

The cattle brought to the Willamette Valley by Ewing Young and the WCC in 1837 were Longhorns from California, and these were the breed of cattle most prevalent in the Pacific Northwest until well into the 1840 s. $^{339}$ Longhorns provided meat but they were poor milk producers, and were considered inferior to the American cattle that began to populate the Willamette Valley in large numbers beginning with the Immigration of $1843.3^{340}$ By the late 1840 s, emigrants had brought thousands of cattle overland to the Willamette Valley, and by 1850 there were so many cattle that many herds were sent to California. ${ }^{341}$ The 1850 federal census reported there were 41,729 head of cattle, including 9,427 milk cows and 8,114 oxen, in the Oregon Territory.

By 1850, American cattle were selling at a 20 percent premium to Longhorns. John Minto said that his immigration party in 1843 brought over 1,000 head of cattle, and that the quality of Oregon's cattle continued to improve with succeeding immigrations. He also recalled that the introduction of purebred cattle

\footnotetext{
338 "A Letter from William Geiger," Report of the Commissioner of Patents: Agriculture, 1850 (Washington D.C.), 14.

339 "Letter from William Geiger," Report, 30.

${ }^{340}$ Gibson, 143; Bowen, 81. See also Herbert Hunt and Floyd C. Kaylor, Washington West of the Cascades (Chicago: S. J. Clarke Publishing Company, 1917), 180; Edward Huggins, the last manager of the Puget Sound Agricultural Company, described the California cattle as so "wild and wicked" that administrator Tolmie sold "killing rights" to settlers who then hunted down hundreds of the loose cattle for five dollars a head.

${ }^{341}$ James R. Robertson, "The Social Evolution of Oregon," Oregon Historical Quarterly (MarchDecember 1902): 17.
} 
began in this period. ${ }^{342}$ Most of the new cattle were shorthorns (also called Durhams) and immigrants favored preferred them for their superior milk and beef qualities. These cattle were well established in the Ohio and Mississippi Valleys-the areas of origin for most overlanders. ${ }^{343}$

In 1929, History Professor C. S. Kingston wrote a scholarly article on the introduction of cattle into the Pacific Northwest. ${ }^{344}$ His was the best work on the subject at the time, only to be surpassed in breadth and detail by Professor Orin J. Oliphant's work four decades later. ${ }^{345}$ In regard to the cattle industry in the pioneer period, Kingston and Oliphant did not find a level of interest comparable to that shown for the sheep industry nor, for that matter, the horticultural industry. It may be the case that the interest in breeding cattle was as high as or greater than that for sheep and horticulture, and that the disparity lies only in the amount of literature produced on behalf of the four industries. However, pioneers did express an interest in improving their cattle: ${ }^{346}$

“... Uncle Johnny Wilson of Linn County brought a drove of Durhams from Henry Clay's herd at Blue Grass Grove which greatly improved the stock of Oregon, for he sold animals all over the state. Captain Benser brought a herd of fine cattle and improved the herds of the Columbia bottoms greatly.

\footnotetext{
${ }^{342}$ Minto, Oregon Historical Society, MSS.

343 Minto, Oregon Historical Society, MSS.; Bowen, 81; 798. Charles Henry Carey, History of Oregon. (Chicago: Pioneer Historical Publishing Company, 1922), 798. Shorthorn cattle descended from Durham cattle and the two names were often used interchangeably. ${ }^{344}$ C. S. Kingston, "Introduction of Cattle into the Pacific Northwest," Washington Historical Quarterly 14 (July 1923).

${ }^{345}$ Orin J. Oliphant, On the Cattle Ranges of the Oregon Country (Seattle: University of Washington Press, 1968).

${ }^{346}$ Ralph C. Geer, "Occasional Address," TOPA (1879): 38.
} 
In 1858, the Fraser River gold rush in British Columbia proved to be a bonanza for Oregon cattlemen. In 1861, 7,081 head of cattle estimated to be worth over $\$ 300,000$ were driven to Victoria, and most of them came from Oregon. ${ }^{347}$

\section{Sheep}

John Minto and Joseph Watt were the most recognizable professional sheep breeders in pioneer Oregon. The thrust of their lifelong engagements in the sheep industry was toward improving the commercial prospects of the animals for wool. ${ }^{348}$ Watt's sheep breeding efforts were almost exclusively market oriented, while Minto, when not selling his sheep, devoted much of his time to progressive husbandry-or the science of agriculture, as it was then expressed. Minto, for example, kept a diary, exhibited his sheep at agricultural fairs, and published numerous articles on improving the breeds. ${ }^{349}$ Watt, on the other hand, engaged in multiple enterprises, including the manufacture of woolen products, farm and sheep operations, and the export market. He was active in community affairs and became one of the leading forces in the establishment of Oregon's first woolen mill in $1858 .^{350}$

\footnotetext{
${ }^{347}$ William J, Trimble, "The Mining Advance into the Inland Empire," Bulletin of the University of Wisconsin (Madison, Wisconsin, 1914), 3: 107; J. Orin Oliphant, "The Cattle Trade from the Far Northwest to Montana, Agricultural History 6 (April 1932): 69-70.

348 Soon after arriving in Oregon in 1844, Watt established his entrepreneurial credentials by trading imported clocks for wheat; see the Oregonian, September 20, 1885. Watt invested his profit into 400 sheep (seven of them purebred) that he bought in Missouri. He then drove them overland to Oregon in 1848; see John Minto, "History of the Introduction of Sheep into Oregon," Oregonian, November 11, 1863.

${ }^{349}$ In 1892, the United States Bureau of Animal Industry chose Minto to write an article concerning the sheep industry in Oregon: John Minto et al., Special Report on the History and Present Condition of the Sheep Industry of the United States, Bureau of Animal Industry, U.S. Department of Agriculture (Washington, D.C.: 1892), 976-991. See also John Minto, "Sheep Husbandry in Oregon," Oregon Historical Quarterly 3 (September 1902): 219-247.

${ }^{350}$ Alfred L. Lomax, Pioneer Woolen Mills in Oregon (Portland, Oregon: Binfords and Mort, 1941), 155-118.
} 
In the mid 1850s, mutton was not common table fare. There were a number of reasons for this, including the poor quality of meat provided by the nation's numerically more numerous wool-producing sheep like the Merino and its relation the Rambouillet. There was also a residual cultural opposition to eating mutton because of a traditional emphasis on using sheep for wool, and because it was considered, since colonial times, to be food fit for only the poor. ${ }^{351}$ Wool breeds as mentioned did not receive top dollar from meat buyers who preferred meatproducing breeds like Cotswold and Shropshire Down. "Wool types" were the sheep most sought after by Minto, Watt, and their peers in Oregon's early sheep industry.

By a consensus of historiographical accounts, Jacob Lease led the first large sheep drive to the American settlement in the Willamette Valley while in the accompaniment of the Gale party in $1843 \cdot{ }^{353}$ Roughly two-thirds of the estimated 3,000 sheep were destined for the HBC under the trail management of McLoughlin's son-in-law, William Rae. ${ }^{354}$ From that point, other American immigrants began to bring sheep overland from the east, with Joshua Shaw putatively the first to do so in 1844 . Of the sheep brought overland during the next four years there were at least six herds, and, according to John Minto, the

\footnotetext{
${ }^{351}$ Meat and Livestock Digest, "Raising Sheep for Meat," July, 1926: 2; in Europe, sheep was considered food for the poor See also Nile's Weekly Register, "Sheep and Wool," Vol. 35, February 14, 1829: 401.

${ }^{352}$ Minto, "Special Report," 980.

353 John Minto, et al., Special Report on the History and Present Condition of the Sheep Industry of the United States, Bureau of Animal Industry, U.S. Department of Agriculture (Washington, D.C.: 1892), 977.; Bowen, 85.

354 John Minto, "Beginning of Agriculture," undated narrative, Oregon Historical Society, MSS 752, Box 2; Frederick Van Voorhies Holman, Dr. John McLoughlin, the Father of Oregon (Cleveland: Arthur H. Clark Company, 1907), 69; reveals that Rae was stationed in Yerba Buena in the spring of 1843 and would have been ideally located for the return to Oregon with Lease.
} 
most notable among them was a large flock owned by Joseph Watt that included purebred Saxony Merinos and Spanish Merinos. ${ }^{355}$ The flock brought to Oregon by Lease in 1843 provided sheep for the valley settlement, but they were a lowquality breed then common in California. However, John Minto crossbred them with his Merinos and produced an improved stock. ${ }^{356}$

There are several accounts of a Hugh Fields who immigrated in 1847 with a flock of sheep that surpassed all others in quality. Nowhere has a name for the breed belonging to Mr. Fields surfaced, although Minto referred to them as "all purpose sheep."357 Mr. Fields and his wife died from the measles before establishing a home and their sheep were then sold off at auction in small lots to become the foundation stock for several Valley flocks. ${ }^{358}$ R. C. Geer, a respected farmer known for his interest in agricultural improvement, was so enamored of Fields' sheep that he called them the best that were ever brought to Oregon. ${ }^{359}$ Minto made most of his profits by selling "fine wool sheep" to other breeders and sheep herdsmen who wanted to improve their herds. ${ }^{360}$ His experiments with crossbreeding resulted in his winning most of the awards for excellence in sheep and wool exhibits at the first state fair in $1861 .{ }^{361}$ By 1892, Minto's reputation in

\footnotetext{
${ }^{355}$ Minto, "Beginning of Agriculture." Oregon Historical Society MSS. See also Bowen, 85-86, wherein Joseph Watt is quoted as stating that 1847 was the year he brought his sheep and a wool-carding machine to Oregon.

${ }^{356}$ Minto, "Beginning of Agriculture." Oregon Historical Society MSS, 221; data on Jones and Rockwell is available in Edward Norris Wentworth, America's Sheep Trails: History, Personalities (lowa State College Press, 1948), 207.

${ }^{357}$ Minto, "Beginning of Agriculture." Oregon Historical Society MSS.

358 John Minto, "Sheep Husbandry in Oregon," Oregon Historical Quarterly 3 (September 1902): 223; according to Minto, five Willamette Valley settlers bought flocks from Fields' estate auction. ${ }^{359}$ Ralph C. Geer, "The Occasional Address," TOPA (1879): 40.

${ }^{360}$ United States Senate, Testimony Taken by the Senate Committee on Relations With Canada, vol. 1 (Washington D.C.: 1890), 195, 198.

${ }^{361}$ Beverly Elizabeth Lowe, John Minto: Man of Courage. 1822-1915 (Salem, Oregon, 1980), 66.
} 
the sheep trade was so well established that the Secretary of Agriculture appointed him to represent the Pacific states and territories for the National Report on Sheep of the United States. ${ }^{362}$

Roxanna White, nee Watt, described how the Watt family helped her brother Joseph Watt to bring more than 400 sheep (mostly Merinos) to Oregon from Missouri in 1848. Joseph had plans for a woolen factory and loaded the wagons with a spinning wheel and a carding machine-including the necessary looms and reels. After the family settled into young Joseph Watt's land claim in Yamhill County, Joseph's mother and sisters cleaned and carded wool and spun yarn for socks and dresses. They made knit socks over that winter and sold one 150 pairs for three dollars and four dollars each. Watt's plans for an early start on his woolen mill were temporarily set aside because the California gold rush presented him with a "quicker but less certain way of getting rich."363

In 1851, Hiram Smith left Ohio overland to Oregon, bringing with him the Territory's first purebred Merino rams. ${ }^{364}$ In 1857, Martin Jesse of Yamhill County bought twenty purebred Merinos from a highly regarded flock that originated in South Wales. ${ }^{365}$ In 1858, R. C. Geer of Waldo Hills, Marion County, imported Southdowns from England. Geer's animals were descendants of a flock raised by Jonas Webb of England, a man who was famous in the world of sheep

\footnotetext{
${ }^{362}$ Beverly Elizabeth Lowe, John Minto: Man of Courage, 67.

${ }^{363}$ Roxanna White, "Impressions of the Common Man," in interview by author Fred Lockley, Oregon Journal, October 1, 1923; Alfred L. Lomax, Pioneer Woolen Mills in Oregon, 61-66.

${ }^{364}$ Minto, Special Report, 977.

365 John Minto, "Sheep Husbandry in Oregon," Oregon Historical Quarterly 3 (September 1902): 223-224.
} 
husbandry for having bred the Southdown to its modern form. ${ }^{366}$ Also in $1858, R$. J. Jones and S. B. Rockwell, two "mercantile" breeders from Vermont, introduced into Oregon forty-five head of Vermont Merinos that were considered to have been improved enough to warrant designation as American Merinos. ${ }^{367}$

Bowen referenced the 1850 agricultural census to name sheep as the most numerically insignificant herd animal in Oregon with a count of only 4,035 head. ${ }^{368}$ But during the next decade, the numbers of sheep rose more rapidly than did any other census enumerated farm animal, accounting for 86,052 head in the 1860 census. It was an attainment that prompted John Minto to write "... 1860 may be said to end the pioneer period of the domestic stock interests of Oregon, especially the sheep husbandry." ${ }^{369}$ The value and quality of purebred sheep was a topic of much discussion, and interest accelerated with the introduction of new breeds and herds. To a large extent, reputation of particular herds determined their market quality and this varied from herd to herd even among the same breed. The reputation of a particular herd of valuable sheep would often be named after its breeder, or, as in the case of the French Imperial Flock of Rambouillet, after European royalty. ${ }^{370}$

The market for wool in Oregon had been restrained until 1858 when a group of local entrepreneurs led by Joseph Watt opened, near Salem, the first woolen mill in the Pacific Northwest. For several years prior to this there had been only

\footnotetext{
${ }^{366}$ Frederick A. P. Barnard, et al., Johnson's (Revised) Universal Cyclopedia: A Scientific and Popular Treasury of Useful Knowledge (New York: A. J. Johnson, 1886), 783.

${ }^{367}$ Minto, "Sheep Husbandry in Oregon," 225.

${ }^{368}$ Bowen, 86.

${ }^{369}$ Minto, "Sheep Husbandry in Oregon," Oregon Historical Quarterly 3 (September 1902): 226.

${ }^{370}$ Minto, "Sheep Husbandry in Oregon," Oregon Historical Quarterly 3 (September 1902): 229.
} 
one wool merchant in Portland, and he paid only ten cents a pound, which was low for the times. ${ }^{371}$ This lack of a viable wool market was likely part of the reason why Oregon's sheep numbers lagged other livestock in the 1840s and into the 1850 s. Farmers were also hesitant to raise sheep because they were defenseless against large predators and required more shelter and attentiveness than did cattle and hogs. ${ }^{372}$

As the 1850 s drew to a close, the sheep industry began shifting to eastern Oregon as farmers discovered the wheat and grazing potential of the Columbia Plain. In 1861, in the Oregon Country's first major sheep operation east of the Cascades, Joseph Watt and two partners sent 4,500 head of sheep to winterover in the Yakima Valley. Beginning in December, snow and ice blanketed the Pacific Northwest for fourteen weeks, marking it as the most devastating winter for domestic livestock in the region to that date. ${ }^{373}$ Minto described the surviving sheep from Watt's herd as "45 living skeletons." 374 Watt was financially devastated, but continued to have faith, as did others, in the pastoral qualities of the Columbia Plain.

As with all livestock operations, the sheep industry was primarily sustained by the economics of supply and demand. But another element, and one that the literature suggests played a substantial role in the improvement of all livestock, was the pride and stature that possession of quality animals bestowed on those who owned them. John Minto, in his article on the history of sheep husbandry in

\footnotetext{
${ }^{371}$ Carey, 796.

${ }^{372}$ G. E. H., "Protection of Stock During Winter," The Country Gentleman, a Journal for the Farm, the Garden, and the Fireside 1 (January to July 1853), 181.

${ }^{373}$ Minto, "Sheep Husbandry in Oregon," Oregon Historical Quarterly 3: 230.

${ }^{374}$ Minto, "Sheep Husbandry in Oregon," Oregon Historical Quarterly 3: 230.
} 
Oregon, iterates the impressive lineage of imported breeds that were esteemed for their wool, and he categorized "mutton" as stock animals fit for driving to the mining camps. Purebred sheep were touted as having French, Spanish, Saxony, English, and Australian or other ancestral blood that was often descended from the private flocks of royalty. ${ }^{375} \mathrm{~A}$ hierarchy of stature in the husbandry culture was demonstrated at fairs and other events where competition for best of show conferred honor on both man and beast. Economic considerations compelled agricultural improvement, but so did the desire for recognition. These ingredients factored into the development of county agricultural societies and the annual fairs they sponsored, as will be examined in chapter six.

\section{$\underline{\text { Hogs }}$}

No other farm animal surpassed the hog's fecundity. Ubiquitous and often running wild in forest and pasture, few farms were without them. In 1850, there were over 30,000 hogs in the Willamette Valley-a number that by far surpassed the enumeration for other categories of livestock. In 1853, a Linn County farmer reported that hogs do well here: "They exist on an onion-like bulb called cameros [Camas bulb] and acorns, and require no other keep as they are well equipped to fend for themselves. ${ }^{\text {"376 }}$ But hogs apparently failed to pique the interest of breeders to the same degree as was the case with sheep and cattle. ${ }^{377}$ Hubert Howe Bancroft and Charles Henry Carey, two major historians of Oregon's pioneer period, give only cursory mention in their works to purebred swine.

\footnotetext{
${ }^{375}$ Frederick A. P. Bernard, et al., eds., Johnson's Revised Universal Cyclopedia (New York: A. J. Johnson and Company, 1886), 783.

376 "Statement from William M. Macy of Quercus Grove, Linn County Oregon," Report of the Commissioner of Patents: Agriculture, 1853 (Washington D.C.), 57.

${ }^{377}$ Bowen, 86-88.
} 
However, in 1861, just prior to Oregon's' first state agricultural fair, the editor of the Oregon Farmer urged farmers to take their improved and diverse hog breeds to the fair and show them off: ${ }^{378}$

We have some of the improved varieties of hogs in this country hogs that will weigh 300 or more pounds. We want to see them at the fair. Many farmers will want to buy of this stock. It may be supposed by those who don't know that one hog is as good as another. For [their] benefit, we want some kind friend in Clackamas to bring to the fair a real, live, long snouted, long legged, big tusked, big 'flop down' eared, high bristled, fern digging, ancient, alligator hog-a real racer.

In 1917, Leslie M. Scott, Vice President of the Oregon Historical Society, wrote that the Berkshire hog was common in Oregon in 1856, but he did not provide a source for this information. ${ }^{379}$ However, there is an extant record from a June 10, 1854 Washington County Agricultural Society meeting in which a committee's plan to host the county's first fair describes an event offering prizes for boars, brood sows, and sow and pigs. ${ }^{380}$ In 1861 , Marion County hosted a livestock exhibition that included a full blood Berkshire boar of "fine proportions," and there were other hogs of "a kind that a farmer would like to look at." ${ }^{381}$ Other evidence of a current of interest in the improvement of swine is in a description of Oregon's first annual fair held in October 1861, during which R. C. Geer exhibited an Irish Grazier and some purebred Suffolks. In addition, there was an "Immensely large Irish Grazier," and Byfields and Berkshires. ${ }^{382}$ The events appear to corroborate Scott's assessment.

${ }^{378}$ Oregon Farmer, September 15, 1861.

${ }^{379}$ Scott, "Soil Repair in the Willamette Valley," Oregon Historical Quarterly 18 (March 1917): 65.

${ }^{380}$ Washington County Agricultural Society, "Secretary's Book," June 10, 1854.

381 Oregon Farmer, May 15, 1861

${ }^{382}$ Oregon Farmer, October 15, 1861. 


\section{$\underline{\text { Horticulture }}$}

The most important American horticulturist in early Oregon was Henderson Luelling, who emigrated from the Midwest in 1847. That fall, he became the first American to introduce grafted fruit trees in Oregon. ${ }^{383}$ In that same immigration party were Joel Palmer, the captain of the wagon train, and R. C. Geer, a farmer. Palmer brought a box of "cultivated fruit trees," and Geer brought a bushel of apple seeds and a half-bushel of pear seeds. ${ }^{384}$ Geer later traded some stock with Luelling and said that the two of them were thus able "to furnish cultivated trees in great numbers at an early day. ${ }^{385}$ Luelling, however, had a much larger assortment of fruit trees and was destined to become the dominant horticulturist in Oregon.

Henderson Luelling learned the nursery business from his father, who was a physician, nurseryman and fruit grower. In 1841, at the age of thirty-two, Henderson became the owner of a nursery business near Salem, lowa. He left this business and, with his wife Elizabeth and fifteen-year-old son Alfred, took the trail to Oregon on April 17, 1847. Before leaving, he carefully packed 700 tree grafts, budded trees, shrubs, vines, and many other plants in soil that he had prepared in two boxes. ${ }^{386}$ The Luellings arrived in Oregon in November 1847.

\footnotetext{
383 J. R. Cardwell, A Brief History of Pomology in Oregon (Portland, OR: Pomological Society 1906), 9.

${ }^{384}$ Geer, "The Occasional Address," TOPA (1879): 34, 41.

${ }^{385}$ Geer, "The Occasional Address," TOPA (1879): 41.

${ }^{386}$ H. M. Williamson, "Henderson Luelling and Seth Luelling, Pioneers of Horticulture in Oregon," in Eighth Biennial Report of the Oregon Board of Horticulture (OBH), 1905, 104; other plants included plums, cherries, quinces, flowering plants, a gooseberry, an Isabella grapevine, and some currant bushes; among the cherries was a Napoleon Bigarreau that was mistakenly renamed a Royal Ann-which designation remains to this day.
} 
They settled in Milwaukie along the Willamette, four miles downriver from Oregon City.

At Milwaukie, Luelling planted a wide assortment of fruit trees, and, in the spring of 1848 , he opened what is recognized as the Willamette Valley's first nursery. ${ }^{387}$ His future brother-in-law, William Meek, shared the family interest in horticulture, and became a partner in the nursery. ${ }^{388}$ The company was short of grafting stock, and the men set about gathering suitable grafting material for their first orchard. At French Prairie and Oregon City they found roots from apple and wild cherry seedlings, and from the Rogue River Valley they acquired roots from wild plums. An oft-repeated anecdote was that one of the root grafts grew a very large red apple that so interested the community that entire families would travel miles to see it. ${ }^{389}$

In 1851, Luelling traveled back east in search of fresh stock for his nursery; that same year, Luelling and Meek possessed an inventory of over 10,000 trees and 100,000 scions of a wide variety of fruit. Henderson's brother Seth Lewelling became a partner in the nursery in 1851 , and by 1853 their business had grown to include four branch nurseries with fourteen employees. ${ }^{390}$ The business was

${ }^{387}$ Cardwell, A Brief History of Pomology in Oregon, 9; William Barlow, "Reminiscences of Seventy Years," Oregon Historical Quarterly 8 (September 1912): 277; describes how, in 1845, he paid heed to bad advice and dumped his large assortment of fruit tree grafts in the Rocky Mountains. Barlow said Luelling came along "two years later than I did." Barlow estimated his loss at $\$ 50,000$.

${ }^{388}$ Alfred Luelling to Mrs. Fidelia Meek, March 3, 1889, in Jane Luelling, ed., "Luelling, Lewelling, Llewellyn-Campbell Family History and Genealogy," MS, Oregon state Historical Society. 389 J. R. Cardwell, "The First Fruits of the Land," Oregon Historical Quarterly 7 (March 1906): 3435.

390 H. M. Williamson, "Henderson Luelling and Seth Luelling, Pioneers of Horticulture in Oregon," in Eighth Biennial Report of the Oregon Board of Horticulture (OBH), 1905, 104. See also speech by Seth Lewelling, "Horticulture in Early Days," $O B H, 1893,243$ wherein Seth describes details of the four nurseries. 
highly profitable, and the men sold nursery stock as well as fruit harvested from their orchards. Henderson Luelling moved to California by the end of 1853, and left the business to his brother, Seth, and William Meek.

Graft plantings were the chosen method of growing fruit trees for most tree horticulturists, although new varieties were occasionally discovered by growing from seed-Joseph Hamilton Lambert of Powell Valley developed the Lambert cherry from a volunteer seedling ${ }^{391}$ Pioneer horticulturist J. R. Cardwell recalled that in 1858, Seth Lewelling planted Oregon's first Italian prune orchard-located on five acres in Milwaukie. ${ }^{392}$

George H. Himes, curator of the Oregon Historical Society from 1899 to 1940 , remembered that, with few exceptions, the orchards in the Puget Sound Basin before 1854 were planted with stock from the Luelling and Meek nursery. ${ }^{393}$ Horticulturist Charles Robinson wrote that all three of the nurseries introduced into Washington Territory in 1854 received their initial stock from Seth Luelling. ${ }^{394}$ The Luelling nursery was the source of numerous orchards in the Willamette Valley throughout the 1850s. In 1851, Ralph Geer bought enough seedlings from

\footnotetext{
${ }^{391}$ Joseph Gaston, Portland, Oregon, its History and Builders (Portland, OR: S.J. Clarke Company, 1911), 578; Cardwell, A Brief History of Pomology in Oregon, 5.

392 J. R. Cardwell, "The First Fruits of the Land," Oregon Historical Quarterly 7 (March 1906): 42.

${ }^{393}$ George H. Himes, "Old Vancouver Tree," in Encyclopedia of Practical Horticulture, eds. Granville Lowther and William Worthington (Seattle: Lowman and Hanford, 1914), 1: 65; Himes recalled that a nursery started up in 1854 near Cowlitz Landing, and that the owner bought his stock from Morton McCarver who in turn had bought his stock from Luelling's nursery. ${ }^{394}$ Charles L. Robinson, "The Romance and Industry of Washington Fruit," Proceedings of the Twenty-fifth Annual Meeting of the Washington State Horticultural Association (December 1929): 8.
} 
Henderson Luelling to plant his fruit tree farm in Waldo Hills with forty-two varieties of apples, fifteen of pears, six of cherries, and five of peaches. ${ }^{395}$

Reminiscing in 1879, Geer said that over the years he had purchased thousands of dollars worth of plants from the Luellings and considered their business to be the "mother of all our nurseries."396 The Oregon Spectator for July 29, 1851 reported that Morton McCarver owned a 15-acre orchard that contained 200 apple trees and a "large number" of other fruit trees. George H. Himes stated that McCarver bought his stock from Luelling's nursery. ${ }^{397}$ Meek sold his half of the nursery in 1857 . Seth held on to his share and became a noted horticulturist in his own right, gaining his principal fame for developing the Black Republican and the Bing cherries. ${ }^{398}$

\footnotetext{
${ }^{395}$ Robert Horace Down, A History of Silverton Country, 232-233; Bancroft, History of Oregon, 1 : 637, note; see also Bancroft, History of Oregon, 2: 257, note.

${ }^{396}$ Geer, "The Occasional Address," TOPA (1879): 41.

${ }^{397}$ Himes, "Old Vancouver Tree," Encyclopedia of Practical Horticulture, 1: 65. George Himes, in "History of Organization of Oregon State Agricultural Society," Oregon Historical Quarterly 8 (December 1907): 333, notes that McCarver won a silver medal for fruit display at the California State Agricultural Society Fair, Sacramento, in 1853.

${ }^{398}$ Himes, "Old Vancouver Tree," 64. There remains speculation that Seth's employee, Ah Bing, played a leading role in the development of the Bing cherry (Seth named the cherry after Ah Bing).
} 


\section{Chapter Five}

\section{Umpqua and Rogue River Valleys}

\section{Umpqua River Valley}

The 111 mile long Umpqua River flows out of the Cascade Mountains and enters the Ocean at Winchester Bay. As one of Oregon's interior streams, It was regarded as second only to the Willamette for its importance as an artery of commerce. ${ }^{399}$ The river and its tributaries are entirely within the boundaries of what is today Douglas County. The Kalapuya Mountains extend 60 miles westerly from the Cascades between Eugene and Roseburg and form a natural boundary between the Willamette and Umpqua river watersheds. Historically, the Kalapuya Mountains have defined a geographical separation between northern and southern Oregon. Scottsburg, 70 miles southwest of Eugene, was the center of commerce in the Umpqua Valley in the 1850s. Scottsburg is located along the Umpqua River twenty-four miles from the Pacific Ocean, and was the head of navigation for sea going ships. The arable land west of Scottsburg consisted of approximately 2,000 acres of rich soil in open meadows, ${ }^{400}$ and the entire valley contained about 1,700 square miles of arable land. ${ }^{401}$

As happened throughout western Oregon, settlement of the Umpqua and Rogue River valleys expanded rapidly after the passage of the Oregon Donation Land Act of 1850. Immigrants hunting for land were drawn to these southern valleys largely because the best lands had been claimed in the more desirable

${ }^{399}$ A. G. Walling, History of Southern Oregon, Comprising Jackson, Josephine, Douglas, Curry, and Coos Counties (Portland, Oregon, 1884), 384.

${ }^{400}$ Walling, 384.

401 "The New Empire: Oregon, Washington, and Idaho," Issued by the Oregon Immigration Board, Portland, Oregon, July, 1888: 7. 
Willamette Valley, and because gold discoveries in northern California and southern Oregon held out the promise of riches from working the land or the gold fields or both. Nevertheless, settling in the area of the southern valleys required forethought and fortitude because it meant forsaking the established social, political, economic, and transportation amenities of the Willamette Valley and Columbia River towns for a more isolated and relatively untested frontier. In addition, Native tribes of the southern valleys fiercely resisted encroachment on their lands, and hostilities between settlers, miners, and tribes continued until 1856 when the last band of indigenous people were resettled on the Siletz reservation. ${ }^{402}$

Jesse Applegate, farmer, professional surveyor, explorer, and road builder, is likely the Umpqua Valley's most recognized pioneer figure. He was born in Kentucky in 1811, and immigrated to Oregon in 1843. In 1849, Applegate was farming and operating a small gristmill on his land in Polk County when he and his family pulled up stakes and resettled at Yoncalla in the upper Umpqua Valley. ${ }^{403}$ George Riddle, twelve-year-old immigrant in 1851, said of Jesse Applegate that he was one of the most giving and grandest men he ever knew. ${ }^{404}$ In December 1851, Applegate responded to a circular from the agricultural Department of the United States Patent Office requesting information on the

\footnotetext{
402 In the summer of 1828, Indians attacked and killed 15 men in Jebediah Smith's party while they were encamped by the Umpqua River. Smith, an American fur trapper, and three of his men survived-see Mackie, 65. Also, see Johansen, 252-the so-called "Rogue wars" lasted until 1856 when the last band of Indians sued for peace and agreed to remove to the Siletz reservation.

${ }^{403}$ Joseph Schafer, "Jesse Applegate: Pioneer, Statesman, and Philosopher," Edmond S. Meany, ed., Washington Historical Quarterly 1 (July 1907): 228. Yoncalla, itself a small valley, is named for the Yoncalla band of the Kalapuyan Indians. Jesse's farm was at the foot of Mount Yoncalla. ${ }^{404}$ George Riddle, "Annual Address," TOPA (1919), 168.
} 
suitability of farmland in different sections of the country. His comments regarding the Umpqua Valley form the gist of the next two paragraphs.

The Umpqua river basin is surrounded by steep and wooded mountains that are capped with narrow ridges. Unlike the expected level topography of most valleys, the Umpqua basin contains many hills, narrow valleys, and ravines. There are neither lakes nor wetlands, but many small streams cascade from the mountains to collect at the northwest corner before spilling over the coastal mountains toward the sea. The valley soil is rich and alluvia but the season is too often short and dry to sustain either a high-yielding or consistently productive vegetable garden or grain crop. However, locals grow potatoes, onions, beets, parsnips, cabbage, and carrots to sell. Potatoes and onions do especially well and are valuable in the mines. Peas and grains are also grown, but most commonly for domestic use. In the final analysis, the Umpqua basin is best used for grazing livestock. ${ }^{405}$

The valley shipping point is Scottsburg. It is at the head of tidewater and ships cannot ascend above it because the water is too fast and shallow. Presently, the best market for farm products is at the mines in the Rogue and Klamath river valleys. Wagons are sometimes used, but the roads are so often bad that pack animals are the most common means of conveyance. ${ }^{406}$ The principal agricultural

\footnotetext{
405 Jesse Applegate, "A letter from Jesse Applegate," Report of the Commissioner of Patents: Agriculture, 1851 (Washington D.C.): 468-474.

${ }^{406}$ For a description of how pack animals were equipped for a long journey, see Charles Wilkes, Narrative of the United States Exploring Expedition during the years 1838, 1838, 1840, 1841, 1842, 5: 217-218. In 1841, Wilkes sent Lt. Emmons with a party of men on an information gathering expedition through the Willamette Valley to San Francisco. Illustrations accompany the description. It is informative to note that flour was the party's "principal provision," carried in sacks, which were in turn wrapped in a "parflesh made of hide."
} 
products are cattle, sheep, hogs, butter, and cheese. Farmers also sell horses and mules at the mines as pack animals. Cattle and sheep can be driven to the mines, and hogs are usually sold as bacon. Three-fourths of the present population in the valley is this year's immigration, so it is expected that they will purchase supplies from neighboring farmers until they become self-sufficient. Since the mining population is estimated at 20,000 , and Umpqua is the nearest farm community, business has been good. ${ }^{407}$

Applegate made little mention regarding the strength of the market for garden crops, nor did he mention the amounts, if any, of these products he packed and sold. He noted that potatoes and onions were valuable at the mines, but did not mention corn even though corn grew well below Scottsburg and evidently sold well in the nearby mines. ${ }^{408}$ Applegate had recently moved to the area, and, with only a season or two of farming in the upper basin at Yoncalla, he may not have had time to become thoroughly versed in the flow of local commerce. His observation that the Umpqua Valley was more suited for grazing than for crops was corroborated by another Umpqua settler in a letter dated January 15, 1850, and printed in the Western Star. Identifying himself only as "Z," the author wrote that grains were grown for "home consumption and to supply the limited demand created by the annual immigration." ${ }^{\prime 409}$ The Applegate family is credited with having introduced the finest quality of sheep into the valley, and the family's stock is said to have been the foundation for many other sheep herds. Applegate

${ }^{407}$ Charles Wilkes, Narrative of the United States Exploring Expedition during the years 1838, 1838, 1840, 1841, 1842, 5: 217-218.

${ }^{408}$ Walling, 394. Walling wrote that the valleys of the Umpqua and Rogue were the only places in Oregon west of the Cascades where corn could be grown with consistent success.

${ }^{409}$ Western Star, March 6, 1851; The Star began publication in Milwaukie, Oregon in 1850. 
was also the first in the Umpqua to raise sheep for their wool. ${ }^{410}$

Regarding potatoes and their value in the mines, Umpqua pioneer Orson A. Stearns told the story of how Jacob Wagner sold potatoes to the miners in 1853. Wagner had settled in the upper Umpqua Valley on a Donation Land Claim in 1851. In 1852, he went to the Willamette Valley and bought a lot of potatoes for a low price. He cut enough eyes out of the potatoes to load two mules, and in the spring of 1853 he planted the eyes in the rich soil along Bear Creek. From this spot he sold potatoes to the emigrants and the miners for the high price of twenty-five cents a pound. Stearns, then ten years old, said his father traded a \$200 wagon for one hundred hills of these potatoes. Thus, young Stearns provided a rare glimpse into the marketing of farm produce in the Umpqua. Another of his reminiscences offered a likely source for much of the agricultural cargo that was packed over the trails from Scottsburg. Stearns spoke of fiftypound sacks of flour that were stiff from having become wet on the pack trail over the Coast Range from the port at Scottsburg. The flour, said Stearns, was imported from Chile. ${ }^{411}$

1850 was the year that the first ocean-going vessel sailed up the Umpqua to Scottsburg, and three years later the first steamship to navigate the Umpqua docked there. ${ }^{412}$ In 1851-1852, a fifty-mile long pack trail opened up from Scottsburg eastbound to Winchester along the California-Oregon Road, and trails constructed from Winchester extended to the mines in the Rogue River and

\footnotetext{
${ }^{410}$ Walling, 395.

411 Orson A. Stearns, (untitled reminiscences), TOPA (1919), 237-238.

${ }^{412}$ Bancroft, History of Oregon 2:178.
} 
Umpqua Valleys. Daily, long pack trains of mules carrying goods to the mines traversed the narrow and crudely built paths. ${ }^{413}$ In 1852 , Scottsburg was the point of departure for an estimated 500 pack mules a day. ${ }^{414}$ In 1853 , Theodore Winthrop, writer, lawyer, and world traveler, stopped in Scottsburg. He wrote that the upper Umpqua Valley provided a "Large business" for farmers who sent mule trains to supply the miners in northern California and southern Oregon. ${ }^{415}$

Over the course of the next few years, residents in the area of the Umpqua and Rogue River valleys petitioned the territorial and federal governments for improvement to the Scottsburg trail and other pathways connecting to the California-Oregon Road. The need for military roads in the area, combined with settler agitation, resulted in the appropriation of money for several projects. In 1855 , one of those appropriations paid for the completion of a road approximately 150 miles long from Scottsburg southbound to what is now Phoenix, Oregon (Historically, this was known as Camp Stuart along the old California-Oregon Road). ${ }^{416}$

Due primarily to the transient nature of the packing business, cargo manifest records do not exist for pack trains leaving Scottsburg or elsewhere in southern Oregon's 1850 s gold rush period. ${ }^{417}$ Given the large number of miners in the sparsely settled region, it is almost certainly the case that the bulk of agricultural

\footnotetext{
${ }^{413}$ Minter, 143; Bancroft, History of Oregon 2: 183.Winchester and its next-door neighbor, Roseburg, were early rivals for commercial growth. Roseburg won the battle when it became the county seat in 1854 .

414 Throckmorton, 165.

415 Theodore Winthrop, The Canoe and the Saddle, John Harvey Williams, ed. (Tacoma, 1913), 253.

${ }^{416}$ Jerilyn Sue Mcintyre, "The Structure of Communication in an Emerging Frontier Community: Jacksonville, Oregon 1852-1856" (Ph.D. diss., University of Washington, 1973), 75-76.

${ }^{417}$ Mcintyre, 101-105.
} 
supplies destined for the mining camps came from farms outside of the local area. For example, it was a regular practice for farmers in the Willamette Valley to haul their agricultural products, most of which were flour and bacon, to within proximity of the southern mines, and then trade with packers who would take the goods to the miners. ${ }^{418}$ The major land routes of agricultural conveyance in this period connected the Willamette Valley, Crescent City, California, and Scottsburg.

Miners combed southern Oregon and northern California looking for that big strike, and farmers close enough to supply them reaped their own bonanza. After miners settled in on a solid strike, their food supply routes quickly encompassed an area of farmlands large enough to accommodate their demands. But over time, miners would begin to raise their own meat and vegetables, farmers close to the mine operations would increase production, and the market would diminish for farms further away. Supplying the mines was never more than a brief lucrative enterprise in the same ephemeral manner as were nearly all of the early mining operations. As noted by Jesse Applegate, "When the mines cease to consume the agricultural products of Umpqua, it is difficult to foresee what other markets might be found ...."419

Located in the upper Umpqua Valley, Winchester and its neighbor Roseburg lay along a stretch of the California-Oregon Road, and by 1852 each of these startup towns had its own flour mill. ${ }^{420}$ The commercial opportunities presented

\footnotetext{
${ }^{418}$ George Riddle, Early Days of Farming (Riddle, Oregon: Riddle Enterprise, 1920), 41.

${ }^{419}$ Jesse Applegate, "A letter from Jesse Applegate," Report of the Commissioner of Patents: Agriculture, 1851, 474.

${ }^{420}$ Bancroft, History of Oregon, 2: 184.
} 
by the flour mills attracted farmers and merchants, and the location became the nucleus of a trading center. Steamboats continued up the Umpqua to Scottsburg with agricultural products in the 1850s, but the Scottsburg trade declined along with the decline in the mining industry, the opening of a road in 1855 to the seaport at Crescent City, and the growth of agriculture and commerce in the Roseburg area. The Crescent City trade negatively impacted commerce for farmers along the Umpqua and the merchants at Scottsburg because its port was closer to the San Francisco entrepôt, and its overland route was several miles closer to the center of mining activity in and around Jacksonville. ${ }^{421}$ Shipping companies preferred to dock at Crescent City because the Umpqua bar was particularly hazardous during foul weather. After the devastating winter floods in 1861-1862 destroyed the lower half of Scottsburg and washed out the military road connecting it with Roseburg, Scottsburg ceased to be an important center of trade. ${ }^{422}$

\section{$\underline{\text { Rogue River Valley }}$}

The Rogue River flows 215 miles from the Cascade Mountains to the Pacific Ocean. Like its neighbor to the north, the Umpqua River, the Rogue River runs through a rocky, high-walled valley bisected by a series of tributary valleys. But unlike the Umpqua, the Rogue is only navigable for small boats. The area encompassed by this lengthy watershed contains about 577 square miles of arable land. ${ }^{423}$ The Rogue River Valley encompasses part of the middle Rogue

\footnotetext{
${ }_{421}$ Bancroft, history of Oregon, 2: 329.

422 Walling, 435.

${ }^{423}$ Willis B. Merriam, "Notes on Historical Geography of Rogue River Valley," Oregon Historical Quarterly 42 (December 1941): 317.
} 
River and is approximately fifteen miles east to west, and forty miles north to south. ${ }^{424}$ Currently, its most prominent cities include Medford, Ashland, and Grants Pass; however, in the 1850s, Jacksonville dominated all other settlements.

For the prospective farmer, the Rogue River Valley presented a strong case for settlement, as noted by pioneer Benjamin Bonney who, after seeing the valley for the first time, remarked on its beauty and how its many locations of open prairie would attract settlers. ${ }^{425}$ An article in the July 27, 1848 Oregon Spectator extolled on the rich soil in the upper part of the valley. On February 29, 1849, another Spectator article urged settlers to take advantage of the valley's "mild and salubrious climate" and "grasses abundant and nutritious."

Before the gold strikes in northern California, little was known about the southern Oregon valleys other than the hostility of the Natives that lived in the Rogue River region. ${ }^{426}$ In the spring of 1851 , white settlement began modestly with the appearance of three cabins occupied by men who ran three ferries across the Rogue River, apparently in anticipation of the next gold strike. At the time, these three small domiciles were the only cabins or houses between the South Umpqua River and Yreka, California, over one hundred miles to the south. ${ }^{427}$ Two Donation Land Claims were filed in the Rogue Valley in 1851, thus

\footnotetext{
${ }^{424}$ Oregonian, July 3, 1852.

${ }^{425}$ Benjamin Bonney, "Recollections of Benjamin Bonney," Fred Lockley, ed., Oregon Historical Quarterly 24 (March 1923): 52.

${ }^{426}$ James Henry Gilbert, Trade and Currency in Early Oregon (New York: Columbia University Press, 1907), 93. Two articles in the Oregon Spectator, dated March 9 and April 20, 1848, remarked that the Umpqua and Rogue Valleys were still unknown and unexplored.

${ }^{427}$ Walling, 336.
} 
marking the beginning of agrarian settlement. ${ }^{428}$ Settlers continued their DLC filings in 1852, and many prospectors filed claims as insurance against failure of their mining ventures. ${ }^{429}$

In the spring of 1852 , several farmers from the Willamette Valley moved to Bear Creek in the Rogue Valley. They planted crops, hoping to take advantage of the trading opportunities in the mining region nearby. ${ }^{430}$ The efforts of these agrarian entrepreneurs typified the course of agricultural commerce in the mining regions: As local farmers strived to fulfill the demand for their products, output from more distant supply networks declined. It was important to be close to the mines because the strength of sales and prices depended on coordinating the arrival of supplies with the strength of demand. It was an unstructured and freewheeling business that gave the advantage to whoever got there first. In the winter of 1852 , miners in the Rogue Valley town of Jacksonville became snow bound. Supplies ran low and prices rose. When packers were able to break through, the first to arrive made a good profit, and those who were behind made less. By the time trader B. F. Dowell arrived, oversupply had set in and he packed his goods off to Yreka.

Population growth in the agrarian settlements of Oregon's southwestern valleys responded in kind with the influx of miners. The most rapid growth came after gold was discovered in the Rogue Valley at Jacksonville in the winter of

\footnotetext{
${ }^{428}$ Walling, 336-337.

429 Gilmore, 307.

${ }^{430}$ Bancroft, History of Oregon 2: 183-184.
} 
1851-1852-other nearby strikes soon followed. ${ }^{431}$ Two months after the gold strike in Jacksonville there were an estimated 100 to 150 miners in the area, and by summer the estimate had grown to between 1000 and 1,500 miners. ${ }^{432}$ Because local agricultural settlement was scarcely underway at the time, most farm products came into the mining areas by pack trains over a network of trails connecting the California-Oregon Road to Jacksonville, the Willamette Valley, Scottsburg, and Yreka. In 1851, Hamilton Campbell, carpenter and Methodist immigrant from the Great Reinforcement of 1840 , envisioned large profits from selling beef in the mining region and brought 800 to 1,000 head of cattle to the Umpqua. ${ }^{433}$ Corvallis became a major loading center for pack trains headed to the mines in southern Oregon and northern California. Nearly every day, long pack trains would load up with flour, bacon, and other goods. ${ }^{434}$

However, Corvallis would experience the same oversupply problems with Jacksonville as Portland merchants and Willamette Valley farmers endured with oversupply in San Francisco. As southern Oregon mines slowed down, commodity prices decreased, and provisioning grew more competitive between packers and a growing southern Oregon farm population. By the spring of 1853 ,

\footnotetext{
${ }^{431}$ Walling, 337, Bancroft, History of Oregon 2: 186. Walling notes the date of discovery was January, 1852, while Bancroft wrote that the strike occurred in February 1852.

${ }^{432}$ Walling, 338.

${ }^{433}$ William L. Lang, Confederacy of Ambition; William Winlock Miller and the Making of Washington Territory (Seattle: University of Washington, 1996), 15-17; relates that Campbell came up with the idea of a 2,000 head cattle drive from California to the Umpqua. Campbell contracted with two other men, but soon was derided as a scofflaw for failure to carry out his plans as stated. See also William G. Robbins, 75, wherein it is noted that Campbell acquired the Methodists' herd during the liquidation and thus accumulated an estimated 1,200 head of cattle. See also Bancroft, 1:222, where it is noted that Campbell bought the Methodists' herd on "long credit," after which he was derisively nicknamed "cow Campbell."

${ }^{434}$ David D. Fagan, History of Benton County, Oregon; Geology, Topography, Soil, and Productions (Portland, Oregon, 1885), 334.
} 
prices for flour in Jacksonville were nearly a third less than they had been in February. ${ }^{435}$ Nevertheless, volatile markets did not deter settlement. Although initially drawn to the area because of its potential for commerce, many of these farm folk came from the valleys of the Ohio and the Mississippi where they had grown accustomed to such marketplace vagaries. ${ }^{436}$

Ten thousand immigrants came to Oregon in 1852, and 7,500 came in $1853,{ }^{437}$ population growth for each year alone was unsurpassed by the immigrant count of any other year between 1840 and $1860 .{ }^{438}$ With suitable land becoming increasingly scarce in the Willamette Valley, many settlers pressed southward into southern Oregon and staked claims in the arable lands of the Umpqua and Rogue rivers. One observer noted that a large number of families staked out claims in the valley of the Rogue in the fall of 1853 and wasted little time in plowing the ground and sowing wheat and other grains for the next year's harvest. $^{439}$

The affect of agricultural settlement was beginning to tip the demographic balance from the gold miner population toward the agrarian class. One example of change is demonstrated by the construction in 1854 of two flour mills on Bear Creek in the northwestern part of the Rogue Valley, followed by the construction of yet another mill when the wheat crop of 1855 proved too large for only two

\footnotetext{
${ }^{435}$ Throckmorton, 167-168; David D. Fagan, History of Benton County, Oregon; Geology, Topography, Soil, and Productions, 334.

${ }^{436}$ Reginald Charles McGrane, The panic of 1837; some financial problems of the Jacksonian era (New York: Russell and Russell inc., 1965), see pp.126-128 for a brief view of the depression's adverse effect on Midwestern agriculture.

${ }^{437}$ Unruh, 120.

438 Unruh, 119-120.

${ }^{439}$ Captain Andrew J. Smith to Joe Lane, December 18, 1853, Oregon Historical Society MSS.
} 
mills. ${ }^{440}$ An article in the Statesman on May 16, 1854, noted that 3,000 acres of wheat had been planted in the Rogue area, and that forecasts for rain augured well for the coming harvest.

In a letter written in 1855 , settler John Tice tells about his farming experience in the Rogue. Tice entered a partnership sometime in 1854, and he and his partners bought 160 acres of land for $\$ 1,000$. They planted 100 acres of wheat, 25 acres of oats, a few acres of barley, and fenced 150 acres. In addition, they built a one and a half story hewed-log house, hauled rails to fence another 100 acres, and had made plans to travel to the Willamette Valley for a reaper so they could harvest their own grain in the fall. ${ }^{441}$ Tice's activities and methods were common practice in the first stage of settlement in the southern Oregon valleys. In 1851, the William Riddle family settled in the Cow Creek Valley near what is now the town of Riddle in the southeast part of the Umpqua watershed. George Riddle, then a young boy, said the first tasks to be accomplished in those days were to build a house, plow the fields, sow the grain, cut and haul rails, and build fence. ${ }^{442}$ Fortunately, the soil in the surrounding valleys was so rich that it "only needed scratching to produce abundant crops." ${ }^{\text {443 }}$ There was no sawmill in southern Oregon at the time, and so the Riddle house was also made from "hewed" pine logs, measured eighteen by thirty feet, and was a story and a half high.

\footnotetext{
${ }^{440}$ Walling, 341-342.

441 John Tice, "A Letter from John Tice," Oregon Historical Quarterly, 37: 43.

442 John Tice, "A Letter from John Tice,", 37-38

443 John Tice, "A Letter from John Tice," 39.
} 
The William Riddle family settled just before the Jacksonville mine discovery, and they witnessed the rapid settlement during the following year. The expanding agricultural community needed farm implements, and since William Riddle was an experienced blacksmith and plow maker he began to produce what was called the Carey plow-a type then commonly used in the Midwest. William Riddle's plows soon became very much in demand by farmers in the area. Because the iron steel required in the construction was not available in southern Oregon, two of the Riddle boys began hauling the metal by wagon from Oregon City. They continued the hauling operation for three summers, ending in $1854 .{ }^{444}$

The Rogue River area was included in the ongoing road improvement efforts discussed in the preceding section regarding the Umpqua Valley. Jacksonville's growing population and proximity (within twelve miles) to the California-Oregon Road helped boost the town into a central position in the region's network of roads and trails. ${ }^{445}$

Hostilities and general discord between whites and Native people continued in a retaliatory fashion during the period to 1856 when the regular army, under the guidance of Superintendant of Indian Affairs, Joel Palmer, forced a final treaty that removed the Rogue Valley's remaining indigenous population to coastal reservations at Siletz and Grande Ronde. During the preceding years, the hostilities had a somewhat chilling effect on agrarian settlement, as there had

\footnotetext{
444 John Tice, "A Letter from John Tice," 40.

${ }^{445}$ Mcintyre, 78.
} 
been many violent skirmishes, including several incidents in which "settlers on the outskirts of the valley had been picked off by ... Indians.,"446

${ }^{446}$ Walling, 362. 


\section{Chapter Six}

\section{County Agricultural Societies and the State Agricultural Society}

Agricultural organizations began in America in the late 1700s and by the mid 1800s had become a traditional community forum for agrarian education and professional improvement. ${ }^{447}$ During the 1830 s and 1840 s there were county agricultural societies in every state and territory in which adult Oregon immigrants had called home, and many of these organizations had existed for decades. ${ }^{448}$ In Oregon, interest in agricultural societies began to circulate in the late 1840s, but none appeared until the formation of the Yamhill County Agricultural Society (YCAS) in October 1853. The delay was due, in part, to the disruption of agricultural production in the wake of the California gold rush, and because of a market that remained relatively stable until the summer of 1853 when flour prices began a rapid and prolonged downturn. ${ }^{449}$ That Oregon's first four county agricultural societies formed over the fall of 1853 and the spring of 1854 suggests that the beginning of an economic collapse had a galvanizing influence on the decision of farmers to form these initial cooperative associations. $^{450}$

\footnotetext{
${ }^{447}$ For a history of agricultural societies in America see Wayne Caldwell Neely, The Agricultural Fair (New York: Columbia University Press, 1935).

${ }^{448}$ Report of the Commissioner of Patents: Agriculture, 1858 (Washington D.C.), 90-212. The Patent Office sent questionnaires to the 912 Agricultural Societies on record in the United States asking for date of origination and other questions. Not all of them responded; for examples, Illinois listed ninety-four societies but only thirty-seven responded, and Missouri listed thirty-two societies and only thirteen responded. For an additional source of dates of origination see, "List of Agriculture Societies and Farmer's Clubs," Books of the Department of Agriculture, July 4, 1876 (Washington D.C., 1876), 1-65; Neely, The Agricultural Fair, 70.

449 Throckmorton, 171-173.

${ }^{450}$ These four county agricultural societies were in Yamhill, Polk, Washington, and Marion Counties-see George H. Himes, "History of Organization of Oregon State Agricultural Society," Oregon Historical Quarterly 8 (December 1907): 317-322; see also Solon Buck, The Granger
} 
Public interest in agricultural societies, however, was evident in the years leading up to the formation of the YCAS. Editorials and letters to the Spectator between 1847 and 1852 expressed interest in agricultural societies as forums for crop experimentation and information sharing in the pursuit of higher quality and yields. Prominent supporters included farmers, the editors of the Spectator and the Statesman, and political luminaries. In 1850, Territorial Delegate Samuel Thurston called for the formation of agricultural societies as a more staid and legitimate path to economic well-being. ${ }^{451} \mathrm{~A}$ farmer's letter to the Spectator called for the establishment of agricultural societies so that "the whole policy of farming could then be properly discussed." ${ }^{252}$ One month later, the same author opined an appreciation of the amount of interest, "taken of late" in the improvement of agriculture in Oregon. In 1853, the Statesman announced the formation of Oregon's first county agricultural society (YCAS), and then summed up the motivation behind it: ${ }^{453}$

There is no part of the world where agricultural and horticultural societies are more necessary, and would be more useful, than in Oregon. The experience and experiments of the states are of little or no service here. Our climate, seasons and soil differ from those of all of them, and agriculture and horticulture here must be conducted upon different systems. New experiments must be tried and new modes adopted. In a great measure everything is to be learned anew. Hence the importance of societies where interchange of opinions and experience may be had.

Oregon's politicians, empowered by the congressional bestowment of territorial

\footnotetext{
Movement (Cambridge: Harvard University Press, 1913), 3, and passim. Buck points out that poor economic conditions were the primary impetus underpinning the formation of farm organizations.

${ }^{451}$ Thurston Address, Oregon Spectator, October 17, 1850.

452 "A Letter from Ploughboy," Oregon Spectator, August 19, 1847 and September 1947.

${ }^{453}$ Oregon Spectator, October 4, 1853.
} 
status in August 1848, worked to strengthen Oregon's agrarian identity on both the domestic and national stage. In an 1849 speech before Congress, Oregon Territorial Governor Joseph Lane opined that gold miners who returned from California should double the population he then estimated at nine thousand. ${ }^{454}$ The course of his address was a testimonial on his territory's beauty, resources, and agricultural richness, and with an emphasis on promoting the well-being of its citizenry with congressional aid for schools. He stressed that education would facilitate the development of Oregon's abundant agricultural promise.

While the years from 1848 to 1852 were inactive in regard to farm organization, farmers recognized the commercial opportunities presented by strong urban growth and an economy flush with gold. In the October 1851 Oregonian, the editor told farmers that more patience and diligence were needed to wrest "wealth and prosperity" from Oregon's abundant agricultural resources because "almost everyone comes here with the idea that he ought to make a fortune in a month or a year at farthest." ${ }^{, 455}$ The editor warned farmers that if they were ever going to supplant California's reliance on Chilean flour, then they must be more patient and industrious. In 1851, an article in the Sacramento Transcript noted that the growing Willamette River towns of Champoeg, Albany, Syracuse, and Marysville were well situated for agricultural commerce. ${ }^{456}$

County and state agricultural societies were family farm groups with a broad range of interests. Although the draw of recreation, fraternity, political influence,

\footnotetext{
${ }^{454}$ Oregon Spectator, "Governor's Message to the Fellow Citizens of the Counsel and the House of Representatives," July 17, 1849.

455 Oregonian, October 4, 1851.

${ }^{456}$ Sacramento Transcript, January 15, 1851.
} 
and thirst for knowledge motivated farmers to form agricultural societies, it was the potential for commercial gain that provided the primary impetus. In 1854, this central motive for the need to improve agriculture found expression in a draft outlining a purpose for awards at Washington County's first agricultural fair: "in awarding premiums on crops, preferences will be given to those yielding the greatest net profit." ${ }^{457}$ Speaking at the Multnomah County Agricultural Society's first annual address in 1860, President Thomas Frazier urged his membership to set examples by producing "better crops, better animals, and better profits." 458 Reminiscing about his home State of Massachusetts, Frazier remarked that agricultural societies were now in every county, and had likely formed in every county in New England because farm families saw their mutual associations as key to "moral and pecuniary" well-being. ${ }^{459}$

In 1859, an editorial in the Oregon Farmer ensured readers that the paper was dedicated to helping farmers make a profit from their industry. In the same column, the Farmer printed the statement of purpose for Lane County's first county agricultural society: "The object of the Society shall be to improve agriculture ... and the breeding and improving of domestic animals [livestock]; and also the improving of farming utensils [farm implements] and domestic manufacture. ${ }^{460}$

\footnotetext{
457 "Secretary's Book," Washington County Agricultural Society, June 10, 1854.

458 Oregon Farmer, January, 1860.

${ }^{459}$ Oregon Farmer, January, 1860.

${ }^{460}$ Oregon Farmer, June, 1859.
} 
On September 17, 1853, a group of farmers met at the Yamhill County Courthouse in Lafayette, Oregon, and began to organize the YCAS. ${ }^{461}$ Three more counties-Polk, Marion, and Washington-quickly formed agricultural societies, and by the end of 1855 all four organizations had hosted county agricultural fairs. ${ }^{462}$ Linn County followed suit when a large number of citizens met at the courthouse in Albany on May 3, $1856 .{ }^{463}$ On November 19, 1859, Thomas Dryer, editor of the Oregonian, addressed members of a meeting that assembled to discuss the organization of an agricultural society in Multnomah County. By 1860 , thirteen county agricultural societies had formed in Oregon—all in the western section of the state, ranging from Multnomah County in the north to Jackson County in the south. ${ }^{464}$

Nearly all of the surviving documents regarding the meetings and assemblies held by these first county farm groups are scattered among the newspapers and journals of the period, and nearly all of that information exists as copies of speeches, resolutions, committee appointments, and ephemera regarding the county fairs. The gist of the aggregate material promoted the economic benefit of agricultural improvement, although uplifting and laudatory rhetoric from those

\footnotetext{
Oregon Statesman, Oct. 4, 1853.

462 George H. Himes, "History of Organization of Oregon State Agricultural Society," Oregon Historical Quarterly 8 (December 1907): 317-323.

463 lbid, 322.

464 Oregon Farmer, May 7, 1860. In 1860, Wasco County (1854) was the only county established in eastern Oregon-a region recognized here as that part of Oregon to the west of the Cascade Mountains.
} 
chosen to deliver public addresses demonstrated that farmers were also inspired by agrarian pride. ${ }^{465}$

All agricultural fairs held competitions for awards in all of the classifications set for exhibition and judging. The more common exhibits included livestock, crops, fruit, poultry, dairy products, farm implements, flour, and vegetables. Contests for household goods included soap, bakery goods, jams, jellies, starch, pickles, wine, vinegar, and embroidery. ${ }^{466}$ Agricultural society members usually received free admission to their organizations' fairs, and nonmembers gained entry by paying an admission fee (usually one dollar or less). Children customarily received free admission when accompanied by a parent. ${ }^{467}$

Although anyone could attend the fairs, participation in competitive exhibits and events was usually limited to dues paying agricultural society members and their children. ${ }^{468}$ In 1860, a contest at the Yamhill County fair was for best

\footnotetext{
${ }^{465}$ Nearly every address before an agrarian audience included many endorsements of agriculture as the nation's most honorable and virtuous occupation. See Ahio Watt's two speeches to the Yamhill County Agricultural Association in the Democratic Standard, Jan. 26, 1856, and the Oregon Farmer, November 25, 1859. Also see George H. Williams' speech to the Multnomah County Agricultural Society in the Oregon Farmer, July 21, 1860: "Kings are more dependent on farmers than farmers upon kings;" "The town is false, impure and imperfect, but the country is true, pure, and beautiful." The country is the farmer's home where "patriotism and public virtue spring up and grow ...."

466 Oregon Farmer, "Clackamas County Fair," October 15, 1860.

${ }^{467}$ See Oregon Farmer, March 10, 1860: 128, where Article three, section four of the Oregon State Agricultural Society (OSAS) constitution states that the male membership has free admission to the annual state fairs, and also free admission to as many as "two ladies" that might accompany him.

${ }^{468}$ County agricultural society membership rules regarding gender were vague. Most of the societies' constitutions state that "any" inhabitant or citizen of a particular county can be a member of that counties' agricultural society. However, there is evidence that suggests only the male head of a family can be a member, and that his family gained membership by virtue of his enrollment. The most suggestive evidence that women could not become individual members is given in a letter to the Oregon Farmer, March 26, 1860 (139), and signed by Daniel Brock. Mr. Brock wrote that Article three, section five of the OSAS constitution referred to members as "he" and "his," which Brock took to mean that women could not by themselves establish a membership. The editor responded to one of Brock's other assertions, but did not respond to Brock's remark about women and membership. This "no-response" implies that Brock was correct
} 
"specimen of knitting by a girl under 10 years old;", 469 and in 1861, a Polk County fair exhibit gave premiums for "best woolen socks, knit by a girl under 12 years. ${ }^{\not 70}$ Every county agricultural society took steps to produce annual fairs, but, on occasion, problems intervened and fairs were canceled -most often because of lack of money or lack of volunteers or both. ${ }^{471}$

Fairs were also places for entertainment and recreation, as demonstrated by an advertisement intended for families coming to the first state fair, held in Clackamas County in October 1861: "The Fair Grounds [sic] are pleasantly situated on the north bank of the Clackamas [River] .... Boats will land near the grounds. There are good camping grounds, with wood and water convenient. For the exercise of horses, trotting, etc., and lady equestrianism, a large field will be enclosed." ${ }^{472}$ In writing about her family's experience at the state fair, one jubilant attendee wrote about having a great experience, and that "Sarah" was going to start making good butter and "John" was so enthused about Suffolk pigs that he was determined to soon own them. ${ }^{473}$

In 1856, Ahio Watt, immigrant from Missouri and the first Secretary of the

because the editor of the Farmer was A.G. Walling - a seated delegate representing Multnomah County at the convention-and the OSAS chose the Farmer as its official "organ." If anyone was in a position to refute Brock's contention that women could not be OSAS members, it was Walling. One other piece of evidence lies in Article three, section four of the OSAS constitution wherein it states that members "have free admission, accompanied by two ladies, to all the exhibitions of the society, and shall be permitted to compete for premiums, in any or all departments." The statement clearly identifies members as men. A more definitive conclusion awaits another study.

469 Oregon Farmer, "Yamhill County Fair," August 6, 1860.

470 Oregon Farmer, May 1, 1861.

${ }^{471}$ Washington County Agricultural Society, "Secretary's Book," June 10, 1855; a committee scheduled a fair to open in the fall of 1854, but plans were delayed one year for lack of volunteers.

472 Oregon Farmer, "Oregon State Fair," September 15, 1861.

473 Oregon Farmer "Oregon State Fair, October 15, 1861. 
Yamhill County Agricultural Society, delivered an address to members of his organization. Watt reminded his audience that in 1853 the YCAS had written into its constitution that it would establish an agricultural and horticultural library, but that the task remained incomplete. Without more interest in education, he worried that agriculture would not make the advances in science and industry that were necessary to regain the stature once enjoyed by farmers in earlier times. ${ }^{474}$ The YCAS and its affiliated societies shared a holistic interest in the agricultural industry, but there were other farm groups with more specific interests.

In response to a letter in the Oregon Farmer suggesting that a horticultural convention be held, fruit growers and nurserymen from seven counties met in Salem on October 20,1858, and formed the Oregon Fruit Growers' Association (OFGA). ${ }^{475}$ The Initial membership role included twenty-three men-among them were horticulturist Seth Lewelling and the publisher of the Oregon Farmer, W.B. Taylor. At the time, there was a growing interest in organizing an Oregon State Agricultural Society (OSAS). The Oregon Fruit Growers' Association and the Oregon Farmer were advocates. In September 1858, an editorial in the Oregon Farmer expressed support and commented that no other state has likely experienced a greater need for such an association. ${ }^{476}$

At the behest of several agricultural societies, A.G. Walling, editor of the Oregon Farmer, ran a series of advertisements in his paper requesting that all counties with delegates elected for the purpose of organizing an OSAS meet at

\footnotetext{
${ }^{474}$ Democratic Standard, Jan. 26, 1856.

475 Joseph Gaston, The Centennial History of Oregon, 1811-1912 (Chicago: S.J. Clarke Publishing Company, 1912), 1: 332; Himes, "History of Organization of Oregon State Agricultural Society," 334-35.

${ }^{476}$ Oregon Farmer, September 1858. The Farmer was a monthly paper at this time.
} 
the Salem courthouse on February 22, $1860 .{ }^{477}$ As Secretary of the Multnomah County Agricultural Society, Walling was also his society's delegate, and he was therefore familiar with the prescriptive elements of the organizing procedure. His advertisements included notes that invited interested parties from counties without agricultural societies to attend the convention, and, from these attendees, delegates would be appointed to represent their respective counties. ${ }^{478}$

Convention organizers seated delegates from nine counties, and over the course of two days (February 22-23, 1860), the delegates constructed a constitution and formed the OSAS. Altogether, the OSAS formally recognized eighteen counties and appointed nineteen men (two for Marion County) to represent their respective counties as president and vice presidents of the OSAS (William Rector of Marion County was president). ${ }^{479}$ The OFGA also sent its three-member executive committee to the convention. Although the OSAS seated these three men as OFGA delegates, they were listed on the OSAS roster as delegates from their respective counties: Thomas T. Eyre, Marion County; William Ruble, Polk County; and Ashby Pearce, Linn County. ${ }^{480}$ During deliberations, OSAS officers invited the OFGA delegates to merge their institution with the OSAS. The three OFGA officers declined, having been

\footnotetext{
${ }^{477}$ At least four such advertisements appeared in the Oregon Farmer: December 7 and December 24, 1859, and January 26 and February 6, 1860. See also Himes, "History of Organization of Oregon State Agricultural Society," 335, and Edna A. Scott, "The Grange Movement in Oregon," (Master's thesis, University of Oregon, 1923), 3.

${ }^{478}$ Oregon Farmer, December 7, 1859, and February 6, 1860.

${ }^{479}$ Oregon Farmer, March 10, 1860: 127. That the OSAS initially seated delegates from only nine of eighteen counties suggests that nine counties did not have active agricultural societies.

${ }^{480}$ For names of the three member OFGA executive committee, see Himes, 338, and Oregon Farmer, April 21, 1860: 148. Note: The March 10, 1860 Oregon Farmer (127) has William Mcllree as one of the three OFGA executive members at the OSAS organizing convention. This is likely meant to be William Ruble because Mcllree is not listed on the membership role as a member of the short-lived OFGA, while Ruble is so mentioned.
} 
authorized only "to confer" with the organizers of the convention. ${ }^{481}$ On September 10, 1860, members of both the OFGA and the OSAS met and approved the merger. The OFGA dissolved, and its treasury went into the coffers of the OSAS. ${ }^{482}$

The constitution, as adopted by the OSAS during its February 1861 convention, provided membership to anyone for $\$ 5$ for the first year, and thereafter $\$ 2.50$ per annum. ${ }^{483}$ Most of the men who organized the OSAS had also helped to organize the county fairs, and this precedent informed the organization of the state fairs. One such precedent involved the establishment of activities for women, as demonstrated by awards for best place in the "Ladies department" of Washington County's first fair in 1855: millinery; needlework; drawing; painting; and loaf of bread. ${ }^{484}$ Eventually, other family inclusive plans would provide for camping sites at fairs, women's equestrian events, and competitive exhibits for children.

A ladies' equestrian riding event at the first state fair involved thirteen participants. It was an event that prompted one man, who entitled himself "a looker on," to express concern that an unruly horse had interfered with a womanly "exhibition of graces." 485 The Oregon Farmer expressed an opinion that even though women and men differed in suitability for certain occupations they were still the equal of one another, and then added a request for "thousands" of

\footnotetext{
${ }_{481}$ Oregon Farmer, April 21, 1860: 148.

${ }^{482}$ Himes, "History of Organization of Oregon State Agricultural Society," 338.

${ }^{483}$ Oregon Farmer, March 10, 1861: 127. See Himes, 339, who notes that the OSAS, at a meeting held on September 10,1860, reduced the initial membership and annual dues to one dollar.

${ }^{484}$ Washington County Agricultural Society, "Secretary's Book," June 10, 1854.

485 Oregon Farmer, October 15, 1861.
} 
women to attend the fair. ${ }^{486}$ In the months and days leading up to the fair, numerous other pleas for women to attend appeared in the Farmer.

Another editorial implored the OSAS committee in charge of premiums to offer agricultural journals to women instead of some trinket to satisfy their vanities. Women, it was opined, are not as vain as the men of the OSAS might think, and some educational material would appeal to their intellectual and moral well-being. While it was conventional to implore women to attend and enter the competitions, there was also the expectation that they would excel only in domestic events. In preparation for its sixth annual fair, the Lane County Agricultural Society appointed three members to each of fourteen committees; only three women were chosen to serve, and they were assigned to the needlework committee. ${ }^{487}$

Little is known about the influence of shared information at agricultural society meetings and at agricultural fairs in effecting changes in the ways individual farmers worked their farms. The Oregon Farmer, and other Oregon newspapers such as the Spectator and Statesman, published many an editorial and letter encouraging agricultural societies and fairs as a source of improvement through experimentation and communication: "Competition is produced by agricultural societies ... and will naturally beget improvement," said Judge George H. Williams in an address delivered before the Multnomah County Agricultural Societyn $1860 .{ }^{488}$ However, that appears to be the extent of the printed media's

\footnotetext{
${ }^{486}$ Oregon Farmer, September 1, 1861.

487 Oregon Farmer, August 1, 1861.

${ }^{488}$ Oregon Farmer, "George H. Williams Address to the Multnomah County Agricultural Society," July 21,1860 .
} 
involvement as almost nothing about gains resulting from such associations appeared in its publications.

Evidence that farmers applied what they learned from fairs and agricultural organizations to work performed on their farms must therefore be inferred indirectly from sources close to and involved with the subject. Sources discussed earlier in this paper include: farm organization statements of purpose; farm organization meeting reports; reports on fair events that include the introduction of new livestock breeds, and new varieties of grains, vegetables, and fruits.

In 1854, cattle exhibits at the Yamhill County fair included only cows, bulls, and oxen. ${ }^{489}$ Held in 1855, the first Washington County fair also did not include cattle breeds. Instead, the competitive awards were for working oxen, bulls, cows, and trained steers. ${ }^{490}$ However, in 1859, Lane County's fair prompted the editor of the Oregon Farmer to remark that there was more purebred stock on view than he had seen anywhere else. ${ }^{491}$ In 1861 , the state fair held exhibits for Devon, Aryeshire, Alderney, and Short Horn cattle breeds. ${ }^{492}$ Also in 1861, at a livestock exhibition hosted by Marion County, several hundred people were on hand to view a diverse number of purebred horse, cattle, sheep, and hog breeds. ${ }^{493}$ The evidence strongly suggests that agricultural societies and competitive exhibits at county and state fairs made significant contributions to the development of agriculture. By 1862, the editor of the Oregon Farmer was

\footnotetext{
${ }^{489}$ George H. Himes, "History of Organization of Oregon State Agricultural Society," Oregon Historical Quarterly 8 (December 1907): 319.

${ }^{490}$ Washington County Agricultural Society, "Secretary's Book," June 10, 1854.

491 Oregon Farmer, October 22, 1859.

492 Himes, "History of Organization of Oregon State Agricultural Society," 342.

${ }^{493}$ Oregon Farmer, May 15, 1861.
} 
confident enough to write, "Annual County and State Fairs, are fixed institutions, are warmly supported by the farmers, and are of incalculable benefit." ${ }^{494}$

${ }^{494}$ Oregon Farmer, August 1, 1862. 


\section{Conclusion}

In the initial stage of frontier agricultural development, farmers labored toward self-sufficiency (food, shelter, clothing), and produced surplus commodities for sale and barter. As urban markets grew, and as transportation networks improved, entrepreneurial farmers began to focus on the cost and profit aspects of agricultural production. Economic and agricultural developments were thus conjoined over time, and evolved amidst disparate patterns of settlement and commerce largely determined by circumstances related to physiography and access to markets. The Oregon frontier settlement, more isolated and more distant from markets than most of its peers, was nevertheless blessed with rich soil, navigable waterways, and lucrative economic opportunities in the midnineteenth century mining regions of northern California and southern Oregon. Given the mix of parallel yet divergent characteristics of agrarian settlement, the task of this study has been to narrate that part of the frontier movement toward a market-oriented agriculture that was distinctively Oregon. I have attempted to accomplish this by highlighting the influence of individuals, organizations, and events as catalysts of economic and agricultural progress.

Pacific Northwest historiography would benefit from a cliometric analysis similar to Atack and Bateman's 1987 study of agriculture in the antebellum North. Such an analysis, with its use of census data and econometric models to examine the economic world of agrarian families, would provide a significant amount of empirical evidence for pioneer-period studies that rely largely on observations found in well-worn primary sources. The need for a fresh economic 
history, however, does not detract from Arthur Throckmorton's signal work on the role of merchants in the development of Oregon economics to 1869. His material provided evidence used in this paper to examine Oregon's three most economically essential occupations-farmer, merchant, shipper-and to determine the interdependent nature of these endeavors as manifested by the impulse of opportunity and the dictate of necessity. 495

Historians have accorded much debate about the conflict between agrarians' pursuit of commercial gain and traditional agrarian values that associated virtue with independent cultivators of the soil. ${ }^{496}$ In essence, the arguments weigh the tensions between the insular, self-reliant farm family and a market-oriented national economy. To accommodate these tensions, Authors Atack and Bateman configured an economic dimension to demographic characteristics such as farm family labor and cultural traditions that placed moral restraints on profit making. ${ }^{497}$ While these cultural tensions undoubtedly existed in Oregon, they received scant notice in the literature, and agrarian ideals appeared to have had little influence on pecuniary interests—as perhaps best demonstrated when more

\footnotetext{
${ }^{495}$ For examples: J. D. Miller hauled freight and worked his orchards: James D. Miller, "Early Oregon Scenes: A Pioneer Narrative," Oregon Historical Quarterly, 31 (September 1930):160180; Henderson Luelling worked his orchards and nursery, and built a grist mill: M. J. Abbey, Llewellyn Traces, a periodical, Vols. 1-4, (1989): 60; and Joseph Watt tended his sheep herds and invested in a woolen manufacturing company: Lomax, 97-106.

496 "The dual nature of the nineteenth-century American agrarian experience intrigues yet bedevils scholars; agriculture was simultaneously a complex, successful economic activity as well as an engine of family and social organization with strong noneconomic motivations. This emerged as an unexpectedly strong theme in the study" (Atack and Bateman, 12).

${ }^{497}$ Money was a necessity, but farmers wanted "pastoral serenity, independent individualism, and psychic rewards, as well as cash flow" (Atack and Bateman, 271). See also Atack and Bateman, 11-13; the authors relied extensively on the 1860 manuscript agriculture censuses for their multistate study. A similar quantitative study for Oregon is hampered because its 1860 agriculture census schedule listing farm household names and individual farm household production is missing;
} 
than half of Oregon farmers abandoned both tradition and farms for the gold mines in 1848.

As de facto guardians of the agrarian tradition, Oregon agricultural societies customarily espoused a blend of ideological loyalties and profit seeking, and only rarely demeaned the latter. ${ }^{498}$ Occasionally, newspapers would warn against the prurient nature of avarice while at the same time praise working the soil as a higher moral order. ${ }^{499}$ However, aside from a few men like John Minto whose devotion to agricultural science was more palpable than his quest for profit, the pace, tenor, and ethos of the farm community was commercialism imbued with a spirit of agrarian virtue..$^{500}$ The point of this exercise has been to substantiate that the development of Oregon agriculture was little hindered by ideological conflict within the agrarian class, and to iterate the cultural rewards, for farmers, of pursuing commerce within the agricultural domain. ${ }^{501}$

Agriculture in early Oregon developed largely in accordance with the blend of skills, experiences, and attitudes that immigrant settlers brought with them. The crops and livestock they raised, and their domestic needs and lifeways were in

\footnotetext{
${ }^{498}$ Agricultural addresses commonly offered examples of the conflation of ideology and profit making: "Why is there so much interest all over the United States in these [agricultural] societies? It is because the people begin to find out that it is for their moral and pecuniary interest to guard well the agricultural interest of this country" (Address of Thomas Frazier, President of the Society, to the Multnomah County Agricultural Society, Oregon Farmer, January, 1860).

${ }^{499}$ For example: "Let Californians go to the mines, let Oregonians plow and sow, harvest and thresh, and in the end Oregon will be infinitely ahead of our neighbors in wealth, morals, happiness, and everything valuable in this life or the future" (Spectator, April 19, 1851).

${ }^{500}$ The theme of nearly every agricultural society address concerned the virtues of yeomanry and working the soil. Note also that in Oregon's small community, news of dishonesty was widely spread; the offender could expect his commercial opportunities to be inhibited along with his reputation; in chapter 6, see "Cow" Campbell, a Methodist immigrant who left Oregon in the wake of a scandal involving a fraudulent business transaction.

${ }^{501}$ In the introduction, see the important role of "improvements" in regard to agricultural development and commerce.
} 
substance unchanged by their new environment and in the main it was an extension of the frontier communities they had left behind. Aside from domestic trade and barter, they sought optimum commercial advantage as permitted by the bounds of physiography, the whims of opportunity, and the limits of entrepreneurial ambition. Such was the familiar dual nature of commerce and agricultural development in the frontier communities of the American West.

Michael Leon Olsen's 1971 Ph.D. dissertation, "The Beginnings of Agriculture in Western Oregon and Western Washington"(1825 to 1900), is in many ways the forebearer of this thesis in that his was also a largely descriptive and inclusive study of agricultural development in Oregon. In general, however, what this study adds to Olsen's work, and to the historiography, is a focus on the salient economic ingredients of agricultural development-with the benefit of 40 additional years of historiographical resources. Other contributions include: Influences of the mining region in and around Jacksonville on agriculture and agrarian settlement in the Umpqua and Rogue River Valleys; the influence of agricultural commerce on the growth of towns, and transportation modes and improvements-including ferries, and expansion of wagon roads through southern Oregon into the northern California mining region; an examination of recent work regarding cultural influences on attitudes toward commerce and agricultural production, and finding evidence that suggests, in Oregon's case, that cultural stereotyping had no credentials; and the inclusion of research into agricultural societies, which are long-neglected but valuable resources for 
examining the economic, political, social, and cultural dynamics of Oregon's first Euro-agrarian community. 


\section{REFERENCES}

\section{Primary Sources}

Allen, A. J., comp. Ten Years in Oregon: Travels and Adventures of Doctor E. White and Lady. Ithaca, New York: Mack, Andrus and Company, 1848.

Ball, John. "Across the Continent Seventy Years Ago." Kate Ball Powers, ed. Oregon Historical Quarterly 3 (March- December 1902).

Barlow, William, "Reminiscences of Seventy Years." Oregon Historical Quarterly 8 (September 1912).

"British and American Joint Commission for the Settlement of the Claims of the Hudson's Bay and Puget's Sound Agricultural Companies." Washington D. C., 1865-1869. Volumes 1-11.

Cardwell, J.R. "First Fruits of the Land." Oregon Historical Quarterly 7 (March 1906): 28-51.

—. A Brief History of Pomology in Oregon. Portland, 1913.

Chambers, Andrew, and Margaret White Chambers. "Reminiscences." Early History of Thurston County, Washington: Together with Biographies and Reminiscences of Those Identified with Pioneer Days, edited by Mrs. George E. Blankenship, 147-172. Olympia, Washington, 1914.

Cole, George E. Jottings of Personal Recollections of a Pioneer of 1850. Washington D.C.: Library of Congress, 1905.

Colton, Walter. Three Years in California. New York: S.A. Rollo and Company, 1859.

Deady, M. P., comp. General Laws of Oregon, 1845-1864 (Portland, Oregon, 1866).

Duis, Dr. E. The Good Old Times in McLean County, Illinois, Containing Two Hundred and Sixty-One Sketches of Old Settlers. Bloomington: The Leader, 1872.

Edwards, Philip Leget. Diary of Col. Philip Leget Edwards Containing an Account of a Trip to the Pacific Coast. Sacramento: A. J. Johnson and Company, 1890.

Sketch of the Oregon Territory or Emigrants' Guide. Liberty, Missouri:

Printed at "Herald" Office, 1842. 
Elliot, T. C., ed. "Extracts from the Journal of Lieut. George Foster Emmons." Oregon Historical quarterly 26 (September 1925).

"Ewing Young Letter to the Oregon Temperance Society." Mission Record Book of the Methodist Episcopal Church. Oregon Historical Quarterly 23 (September 1922).

Farnham, Thomas. Travels in the Great Western Prairies, the Anahuac and Rocky Mountains and in the Oregon Territory. New York: Greeley and McElrath, 1843.

Gale, Joseph "The Schooner Star, an Account of her Construction and Voyage to California." Transactions of the Oregon Pioneer Association, 1891. Portland, Oregon: A. Anderson and Company.

Geer, Ralph C. "Occasional Address," Transactions of the Oregon Pioneer Association, 1879. Portland, Oregon: A. Anderson and Company.

Geer, T. T. Fifty Years in Oregon. New York: Neale Publishing Company, 1912.

Geiger, William. "A Letter from William Geiger." U. S. Patent Office: Agriculture Report, 1850.

Gilliam , Washington Smith. "Reminiscences of Washington Smith Gilliam." Transactions of the Oregon Pioneer Association, 1903.

Gray, W. H. A History of Oregon, 1792-1849: Drawn from Personal Observation and Authentic Information. Portland, Oregon: Harris and Holman, 1870.

Hastings, Lansford Warren. The Emigrant's Guide to Oregon and California. Princeton: Princeton University Press, 1932.

H. G. E. "Protection of Stock During Winter," The Country Gentleman, a Journal for the Farm, the Garden, and the Fireside 1 (January to July 1853).

Himes, George H. "Old Vancouver Tree." Encyclopedia of Practical Horticulture, edited by Granville Lowther and William Worthington. Seattle: Lowman and Hanford, 1914.

- "History of Organization of Oregon State Agricultural Society." Oregon Historical Quarterly 8 (Dec. 1907).

_. Oregon Historical Society MSS. 
Hines, Gustavus. Life on the plains of the Pacific. Oregon: its history, condition, and prospects ... embracing extended notes of a voyage around the world. Geo. Derby and Company, 1851.

. Oregon and its Institutions; Comprising a Full History of the Willamette University, the First Established on the Pacific Coast. New York: Carlton and Porter, 1868.

Howison, Neil M. Oregon, A Report. Fairfield, Washington: Ye Galleon press, 1967.

Labonté, Louis II. "Reminiscences of Louis Labonté." Interview by Horace S. Lyman. Oregon Historical Quarterly 1 (March-December, 1900): 169-188.

Lee, Daniel, and J. H. Frost. Ten Years in Oregon. New York, 1844.

Lee, Jason. MSS 1212, Oregon Historical Society.

Luelling, Jane, ed. Alfred Luelling to Mrs. Fidelia Meek, March 3, 1889, in "Luelling, Lewelling, Llewellyn-Campbell Family History and Genealogy." MSS, Oregon state Historical Society.

Macgregor, John. The Progress of America: From the Discovery by Columbus to the year 1846. Vol. 2. London: Whitaker and Company, 1847,

McLoughlin, John. "Copy of a Document Found among the Private Papers of the Late Dr. John McLoughlin." Transactions of the Oregon Pioneer Association, 1880.

Miller, James D. "'Early Oregon Scenes: A Pioneer Narrative." Oregon Historical Quarterly 31 (March 1930).

Minto, John "Beginning of Agriculture." Undated Narrative. Oregon Historical Society MSS 752, Box 2.

- . "Development of the Cattle Industry," undated narrative. Oregon Historical Society, MSS 752, Box 2.

—. "Letter to George Himes." September 15, 1899. MSS 752, Box 2. . "From Youth to Age as an American." Oregon Historical Quarterly 9 (June 1908).

_. "Special Report on the History and Present Condition of the Sheep Industry of the United States." Bureau of Animal Industry, U.S. Department of Agriculture. Washington D.C.: Government Printing Office, 1892. 
_. "Beginning of Agriculture." Undated narrative. Oregon Historical Society MSS 752, Box 2.

_. "Sheep Industry in Oregon." Oregon Historical Quarterly 1 (September 1902).

"Mission Record Book of the Methodist Episcopal Church, Willamette Station, Oregon Territory, North America, Commenced 1834." Oregon Historical Quarterly, 23 (September 1922).

Rich, E.E., ed. The Letters of John McLoughlin from Fort Vancouver to the Governor and Committee. 1st, 2d, 3d ser. Toronto: Champlain Society, 1825-46.

“Secretary's Book." Washington County Agricultural Society, June 10, 1854.

Shafer, Joseph, ed. "Documents Relative Warre and Vavasour's Military Reconnoisance [sic] in Oregon, 1845-6." Oregon Historical Quarterly 10 (March 1909).

Slacum, William A. "Slacum's Report on Oregon," Oregon Historical Quarterly 13 (June 1912): 175-224.

Thurston, Samuel R. "Address to His Constituents." Oregon Spectator, September 26, October 3, 10, and 17, 1850.

Townsend, John R. Narrative of a Journey Across the Rocky Mountains to the Columbia River and a Visit to the Sandwich Islands and Chile with a Scientific Appendix. Philadelphia: Henry Perkins, 1839.

Watson, Elkanah. "Elkanah Watson Papers, 1773-1884." New York State Library. Manuscripts and special collections.

Watt, Ahio S. "Agricultural Address." Paper presented before the Yamhill County Agricultural Society. Democratic Standard, January 26, 1856.

. "Address of A. S. Watt," Presented at the annual conference of the Yamhill County Agricultural Society, McMinnville, OR. Oregon Farmer, November 25, 1859.

Wilkes, Charles. Narrative of the United States Exploring Expedition during the years 1838, 1838, 1840, 1841, 1842. V. 4, Philadelphia, 1856.

Williams, George H., "Address Delivered Before the Multnomah County Agricultural Society." Oregon Farmer, July 21, 1860. 
Winthrop, Theodore. The Canoe and the Saddle, John H. Williams ed. Tacoma, 1913.

Wyeth, Nathaniel J., "The Correspondence and journals of Captain Nathaniel Wyeth," 1831-36. Edited by F. G. Young. Sources of the History of Oregon Eugene: University Press, 1899.

\section{Secondary Sources}

Atack, Jeremy, and Fred Bateman. To Their Own Soil: Agriculture in the Antebellum North. Ames, lowa: University of lowa Press, 1987.

Atwood, Reverend A. American Settlement of the Oregon Country: Embracing Facts in the Life and Work of Reverend Jason Lee. Tacoma: Washington State Historical Society 1907.

Barnard, Frederick A. P., et al. Johnson's (Revised) Universal Cyclopedia: A Scientific and Popular Treasury of Useful Knowledge. New York: A. J. Johnson, 1886.

Bailey, L. H. Cyclopedia of American Agriculture. New York: The Macmillan Company, 1911.

Bancroft, Hubert Howe. History of Oregon, 1834-1888. 2 volumes. San Francisco, 1886-1888.

Bashford, James W. The Oregon Missions: The Story of How the Line Was Run Between Canada and the United States. New York: The Abingdon Press, 1918.

Bell, James Christy, Jr. Opening a Highway to the Pacific 1838-1846. New York: Longmans, Green and Company, 1921.

Black, Lloyd D. "Middle Willamette Valley Population Growth." Oregon Historical Quarterly 43 (March 1902).

Boag, Peter G. Environment and Experience: Settlement Culture in Nineteenth Century Oregon. Berkeley: University of California Press, 1993.

_. "Political Censorship in the Oregon Spectator." Pacific Historical Review 31 (August 1962): 235-240.

Bowen, William A. The Willamette Valley: Migration and Settlement on the Oregon Frontier. Seattle: University of Washington Press, 1976. 
Brosnan, Cornelius J. Jason Lee, Prophet of Oregon. New York: The Macmillan Company, 1932.

Brown, J. Henry. Political History of Oregon. Portland, Oregon: Lewis and Dryden, 1892.

Campbell, Angus, Philip Converse, Warren E. Miller, and Donald E. Stokes. The American Voter. New York: John Wiley and Sons, 1960.

Carey, Charles Henry. History of Oregon. Chicago: The Pioneer Historical Publishing Company, 1922.

Carter, Harvey L. "Rural Indiana in Transition, 1850-1860." Agricultural History 20 (April 1946).

Caughey, John Walton. The California Gold Rush. Berkeley: University of California Press, 1948.

Clarke, S. A. Pioneer Days of Oregon History. 2 volumes. Portland, Oregon: J. K. Gill Company, 1905.

Cleland, Robert Glass. A History of California: The American Period. New York: Macmillan Company, 1922.

Collins, Dean. Star of Oregon. Portland, Oregon: Binford and Mort, 1943.

Corning, Howard McKinley. Willamette Landings: Ghost Towns of the River. Portland, Oregon: Oregon Historical Society, 1947.

Dodds, Gordon B. Oregon: A Bicentennial History. New York: W. W. Norton and Company, 1977.

Danhof, Clarence H. Change. Agriculture: The Northern United States, 18201870. Cambridge, Massachusetts: Harvard University Press, 1969.

Dore, Benjamin. "The Journal of Benjamin Dore: One of the Argonauts." California Historical Society Quarterly 2 (July 1923).

Douglas, Jesse Steiwer. "Syracuse and Santiam City." Oregon Historical Quarterly 32 (September 1931).

Down, Robert Horace. History of Silverton. Portland, Oregon: Berncliff Press, 1926.

Etcheson, Nicole. The Emerging Midwest: Upland Southerners and the Political Culture of the Old Northwest. Bloomington: Indiana University Press, 1996. 
Fagan, David D. History of Benton County, Oregon; Geology, Topography, Soil, and Productions. Portland, Oregon, 1885.

Faragher, John Mack. Sugar Creek: Life on an Illinois Prairie. New Haven: Yale University Press, 1986.

Fenton, W. D. "The Winning of the Oregon Country." Oregon Historical Quarterly 6 (December 1905).

Fickin, Robert E. "The Fraser River Humbug: Americans and Gold in the British Pacific Northwest." The Western Historical Society 33 (Autumn 2002).

Gaston, Joseph. Portland, Oregon, its History and Builders. Portland, OR: S.J. Clarke Company, 1911.

Gaston, Joseph and George H. Himes. The Centennial History of Oregon, 18111912. Chicago: S. J. Clarke Publishing Company, 1912.

Gibson, James R. Farming the Frontier: The Agricultural Opening of the Oregon Country 1786-1846. Vancouver, B.C.: University of British Columbia Press, 1985.

Gilbert, James Henry. Trade and Currency in Early Oregon. New York: Columbia University Press, 1907.

Hines, Gustavus. Wildlife in Oregon: Being a Stirring Recital .... New York: Washington and Company, 1889.

Holmes, Kenneth L. Ewing Young: Master Trapper. Portland, Oregon: Binfords \& Mort, 1967.

Hoover, Mildred Brooke, Hero Eugene Rensch, Ethel Grace Rensch, and William N. Abeloe. Historic Spots in California. Revised by Douglas E. Kyle. Stanford: Stanford University Press, 1990.

Horner, John B. Oregon: Her History, Her Great Men, Her Literature. Corvallis, Oregon: Gazette Times, 1919.

Hunt, Herbert and Floyd C. Kaylor. Washington West of the Cascades. Chicago: S. J. Clarke Publishing Company, 1917.

Jackson, Ronald Vern. Oregon Census Index, 1840-1849. North Salt Lake, Utah: Accelerated Indexing Systems, 1980. Oregon Census Index, 18501859. North Salt Lake Utah: Accelerated Indexing Systems, 1985. 
Hussey, J. A. Champoeg: Place of Transition. Portland, Oregon: Oregon Historical Society, 1967.

Johansen, Dorothy O., and Charles M. Gates. Empire of the Columbia: A History of the Pacific Northwest. New York: Harper and Row, 1967.

Johnson, David Alan. Founding the Far West: California, Oregon, and Nevada, 1840-1890. Berkeley: University of California Press, 1992.

Lang, William L. Confederacy of Ambition; William Winlock Miller and the Making of Washington Territory. Seattle: University of Washington, 1996.

Lemmer, George F. "The Early Agricultural Fairs of Missouri." Agricultural History 17 (July 1943).

Lowe, Beverly Elizabeth. John Minto: Man of Courage. 1822-1915. Salem, Oregon, 1980.

Kingston, C. S. "Introduction of Cattle into the Pacific Northwest." Washington Historical Quarterly 3 (July 1923).

Kuykendall, Ralph S. The Hawaiian Kingdom, 1778-1854, Foundation and Transformation. Honolulu: University of Hawaii, 1938.

Leet, Don R., Population Pressure and Human Fertility Response: Ohio, 18101860. (Arno Press, 1978), 108-109.

Lomax, Alfred L. "History of Pioneer Sheep Husbandry in Oregon." Oregon Historical Quarterly 29 (June 1928).

- Pioneer Woolen Mills in Oregon; History of Wool and the Textile Industry in Oregon, 1811-1875. Portland, Oregon: Binfords \& Mort, 1941.

Lyman, Horace S. History of Oregon: The Growth of an American State. New York: North Pacific Publishing Society, 1903.

MacColl, E. Kimbark. Merchants, Money, and Power: The Portland Establishment, 1843-1913. USA: The Georgian Press, 1988.

Mackie, Richard Somerset. Trading Beyond the Mountains: The British Fur Trade on the Pacific, 1793-1843. Vancouver: University of British Columbia Press, 1997.

Maloney, Alice B. "Hudson's Bay Company in California." Oregon Historical Quarterly 37 (March 1936). 
Marshal, William I. Acquisition of Oregon and the Long Suppressed Evidence About Marcus Whitman. Seattle: Loman and Hanford, 1911.

Marschner, Janice. Oregon 1859: A Snapshot in Time. Portland, Oregon: Timber Press, 2008.

McDonald, Lois Halliday. Fur Trade Letters of Francis Ermatinger. Glendale, California: Arthur H. Clark Company, 1980.

McMaster, John Bach. A History of the People of the United States. New York: D. Appleton and Company, 1920. Vol. 7 (1841-1850).

Meinig, D. W. The Great Columbia Plain; A Historical Geography, 1805-1910. Seattle: University of Washington Press, 1995.

Minter, Harold Avery. Umpqua Valley and its Pioneers. Portland, Oregon: Binfords and Mort, 1967.

Neely, Wayne Caldwell. The Agricultural Fair. New York: Columbia University Press, 1935.

Oliphant, J. Orin. On the Cattle Ranges of the Oregon Country. Seattle: University of Washington Press, 1968.

_ . "The Cattle Trade on Puget Sound, 1858-1890," Agricultural History 7 (July 1933).

_- "Thomas S. Kendall's Letter on Oregon Agriculture, 1852." Agricultural History 9 (October 1935).

_. "The Cattle Trade from the Far Northwest to Montana." Agricultural History 6 (April 1932).

Paul, Rodman W. "After the Gold Rush: San Francisco and Portland" Pacific Historical Review 51 (February 1982).

Peskin, Lawrence A. A Manufacturing Revolution: The Intellectual Origins of Early American Industry. Baltimore: Johns Hopkins University Press, 2003.

Powell, Fred Wilbur. "Hall Jackson Kelley" Oregon Historical Society 18 (September 1917).

Query, Charles F. A History of Oregon Ferries since 1826. Santa Cruz, California, 2008. 
Robbins, William G. Landscapes of Promise: The Oregon Story, 1800-1940. Seattle: University of Washington Press, 1997.

Robinson, Charles L. "The Romance and Industry of Washington Fruit." Proceedings of the Twenty-fifth Annual Meeting of the Washington State Horticultural Association (December 1929).

Rugh, Susan Sessions. Our Common Country: Family, Farming, Culture, and Community in the Nineteenth-Century Midwest. Bloomington: Indiana University Press, 2001.

Scott, Leslie M., "Soil Repair in the Willamette Valley." Oregon Historical Quarterly 18 (March 1917).

Schafer, Joseph. "Jesse Applegate: Pioneer, Statesman, and Philosopher." Ed. Edmond S. Meany, Washington Historical Quarterly 1 (July 1907).

Seeger, Martin L., "Rocky Mountain Sea Captain." The American Neptune: A Quarterly of Maritime History, 1968.

Speulda, Lou Ann. Champoeg: A Perspective of a Frontier Community in Oregon, 1830-1861. Corvallis: Department of Anthropology, Oregon State University, 1988.

Throckmorton, Arthur L. Oregon Argonauts. Portland, OR: Oregon Historical Society, 1961.

Trimble, William J, "The Mining Advance into the Inland Empire." Bulletin of the University of Wisconsin. Volume 3. Madison, Wisconsin, 1914,.

True, Alfred Charles. A History of Agricultural Education in the United States: 1785-1925. Washington D.C.: United States Government Printing Office, 1929.

Unruh, John D. Jr. The Plains Across: The Overland Emigrants and the TransMississippi West, 1840-60. Chicago: University of Illinois Press, 1979.

Walling, A. G. History of Southern Oregon, Comprising Jackson, Josephine, Curry, and Coos Counties. Portland, Oregon, 1884.

Wells, Harry L. A Popular History of Oregon. Portland, OR, 1889.

Wentworth, Edward Norris. America's Sheep Trails: History, Personalities. lowa State College Press, 1948. 
Widder, Keith R. Michigan Agricultural College: The Evolution of a Land Grant Philosophy. East Lansing, Michigan: Michigan State University Press, 2005.

Williamson, H. M. "Henderson Luelling and Seth Luelling, Pioneers of Horticulture in Oregon." Eighth Biennial Report of the Oregon Board of Horticulture (OBH), 1905.

Winther, Oscar Osburn . The Old Oregon Country: A History of Frontier Trade, Transportation, and Travel. Stanford, California: Stanford University Press, 1950.

- "California Stage Company in Oregon." Oregon Historical Quarterly 35 (1934).

. "Commercial Routes from 1792 to 1843 by Sea and Overland." Oregon Historical Quarterly 42 (September 1941).

_. "Early Commercial Importance of the Mullan Road." Oregon Historical Quarterly 46 (1945).

_. "Pack Animals for Transportation in the Pacific Northwest." Pacific Northwest Quarterly 34 (1943).

_ "Roads and Transportation in Territorial Oregon." Oregon Historical Quarterly 41 (March 1940).

Wise, William N. "The History of Potatoes in Oregon." Dictionary of Oregon History. Portland, Oregon: Binfords and Mort, 1989.

Woodward, Walter Carleton. The Rise and Early History of Political Parties in Oregon 1843-1868. Portland, Oregon, J. K. Gill Company, 1913.

Wright, E. W., ed. Lewis and Dryden's Marine History of the Pacific Northwest. Portland, Oregon: Lewis and Dryden, 1895.

Young, F. G. "Financial History of Oregon." Oregon Historical Quarterly 7 (December 1906). . "Ewing Young and his Estate." Oregon Historical Quarterly 21 (September 1920).

_. Editor. The Correspondence and Journals of Nathaniel J. Wyeth. Eugene, OR: University Press, 1899. 


\section{Theses and Dissertations}

Brier, Warren J. "A History of Newspapers in the Pacific Northwest." Ph.D. diss., State University of lowa, 1957.

Gilmore, Jesse Lee, "A History of the Rogue River Valley-Pioneer Period, 18501962." Ph.D. diss., University of California, 1952.

Jetté, Melinda Marie. "'At the Hearth of the Crossed Races': Intercultural Relations and Social Change in French Prairie, Oregon, 1812-1843." Ph.D. diss., University of British Columbia, 2004.

Keeler, Elizabeth. "The Landscape of Horticultural Crops in the Willamette Valley From 1850-1920." Ph.D. diss., University of Oregon, 1994.

Mcintyre, Jerilyn Sue. "The Structure of Communication in an Emerging Frontier Community: Jacksonville, Oregon 1852-1856." Ph.D. diss., University of Washington, 1973.

Olsen, Michael Leon. "The Beginnings of Agriculture in Western Oregon and Western Washington.” Ph.D. diss., University of Washington, 1971.

Scott, Edna A. The Grange Movement in Oregon, 1873-1900. Master's thesis, University of Oregon, 1923.

Tattersall, James N. "The Economic Development of the Pacific Northwest to 1920." Ph. D. diss., University of Washington, 1960.

\section{Other Sources}

"The New Empire: Oregon, Washington, and Idaho." Issued by the Oregon Immigration Board. Portland, Oregon. July 1888: 7.

\section{Newspapers}

Democratic Standard, 1855-1860.

Franklin Missouri Intelligencer, July 16, 1821, Dec. 17, 1822.

Meat and Livestock Digest. July, 1926.

Nile's Weekly Register. Volume 35, February 14, 1829. 
Oregon Spectator, 1846-1855.

Oregon Statesman, 1851-1861.

Oregonian, 1850-1861.

Portland Daily Advertiser, 1859-1861.

Register-Guard, 2007.

\section{Government Documents}

California State Mining Bureau, Bulletin 30 (June 30, 1903): 268.

Durand, E. Dana, ed., "Statistics for Oregon," Thirteenth census of the United States, (Washington D. C., 1910).

Kennedy, Joseph C. G., Superintendent of Census. The United States in 1860. Compiled From the Original Returns of The Eighth Census, Under The Direction of the Secretary of the Interior. Washington, D. C., 1864.

"List of Agriculture Societies and Clubs." Farmer's Books of the Department of Agriculture, July 4, 1876. Washington, D C., 1876.

Report of the Commissioner of Patents: Agriculture. Washington, D. C., 18501866 (annual publication).

"Statutes of a General Nature Passed by the Legislative Assembly of the Territory of Oregon," 2d sess., 1850-1851. Oregon City, 1851.

\section{Electronic Sources}

Cropp, Bob and Truman Graf. "The History and Role of Dairy Cooperatives," http://www.uwcc.wisc.edu/info/dairy/history.pdf. January 2001.

James Kenneth Munford and Charlotte L. Wirfs. "The Ewing Young Trail." http://www.bentoncountymuseum.org/research/EwingYoungTrail.cfm. (n.d.)

Oregon State Fair, n.d. http://www.oregonstatefair.org/about-the-fair/fair-history. (April 15, 2010).

California Digital Newspaper Collection. http://cdnc.ucr.edu/ 
Jetté, Melinda Marie. "'we have allmost Every Religion but our own': FrenchIndian Community Initiatives and Social Relations in French Prairie, Oregon, 1834-1837." Oregon Historical Quarterly (Summer 2007).

http://www.historycooperative.org/journals/ohq/108.2/jette.html. (26 Nov. 2010). 
Figure 1. Map of Western Oregon (1851)

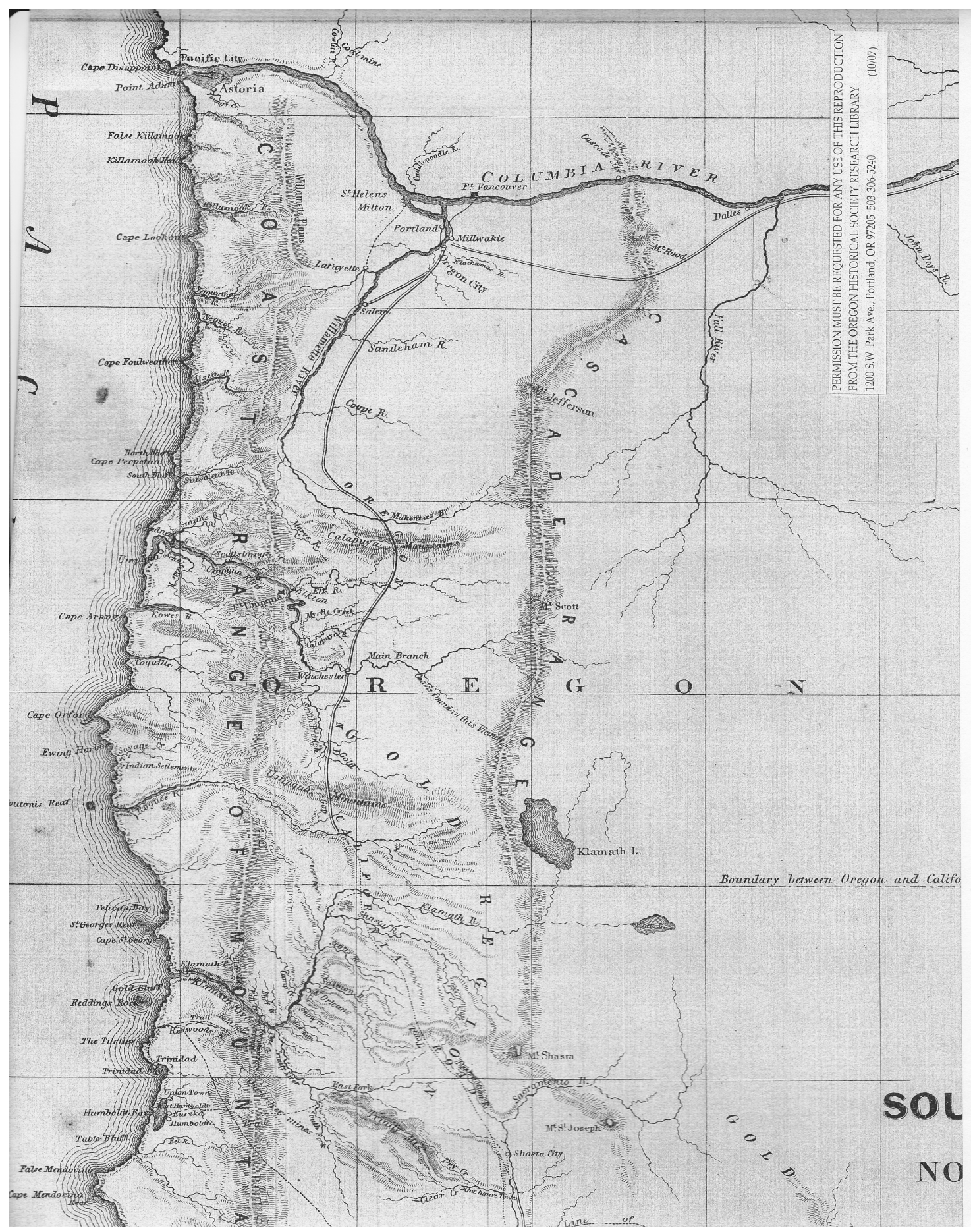

From the United States Coast Guard Survey by N. Scholfield. Reprinted with permission from the Oregon Historical Society. 
Figure 2. Lower Willamette Valley About 1834

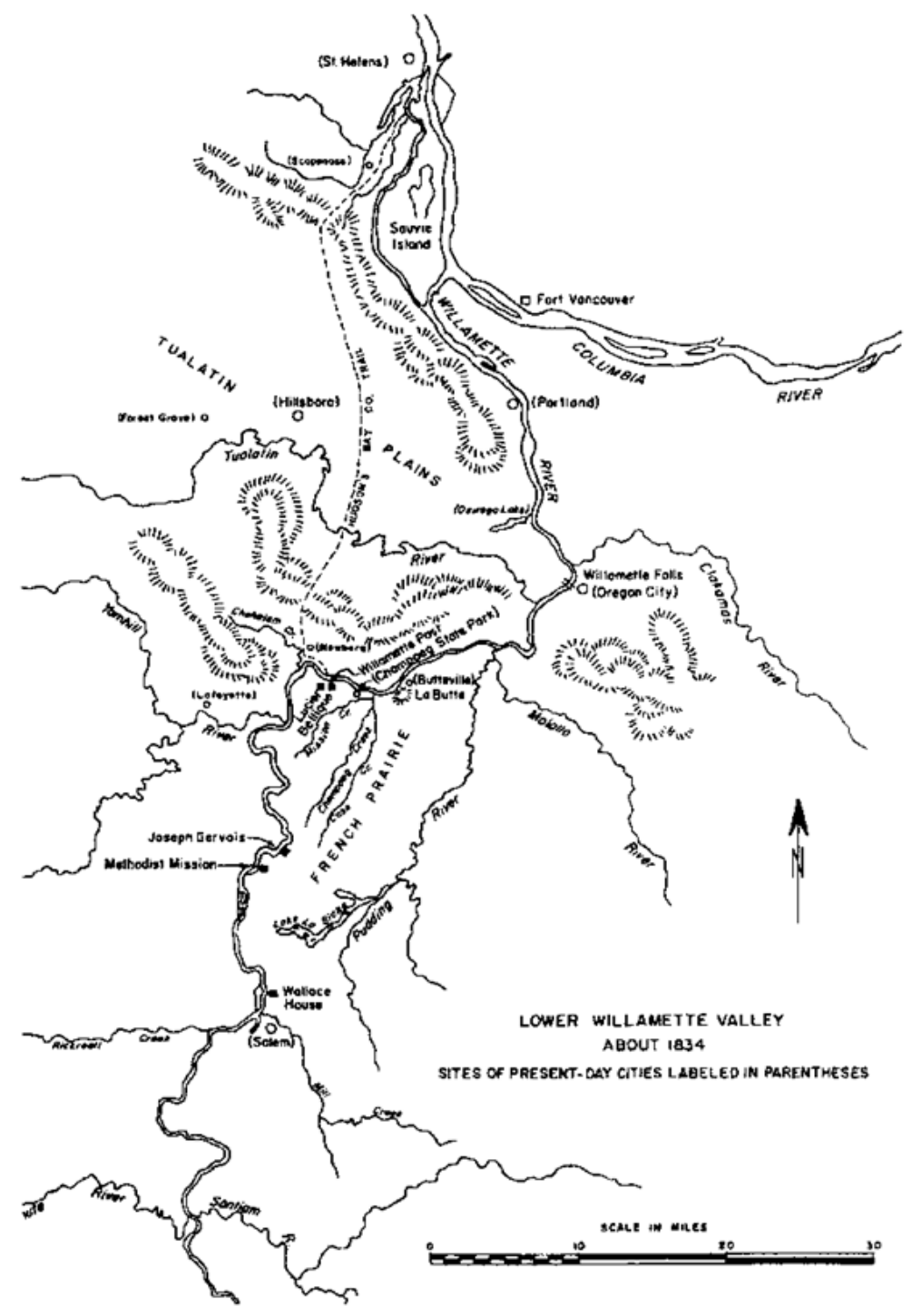

From Hussey, Champoeg: Place of Transition

Reprinted with permission from the Oregon Historical Society 